\title{
WestVirginiaUniversity
}

THE RESEARCH REPOSITORY @ WVU

Graduate Theses, Dissertations, and Problem Reports

2005

\section{Organic poultry production and forage digestibility}

\author{
Nancy P. Buchanan \\ West Virginia University
}

Follow this and additional works at: https://researchrepository.wvu.edu/etd

\section{Recommended Citation}

Buchanan, Nancy P., "Organic poultry production and forage digestibility" (2005). Graduate Theses, Dissertations, and Problem Reports. 2211.

https://researchrepository.wvu.edu/etd/2211

This Thesis is protected by copyright and/or related rights. It has been brought to you by the The Research Repository @ WVU with permission from the rights-holder(s). You are free to use this Thesis in any way that is permitted by the copyright and related rights legislation that applies to your use. For other uses you must obtain permission from the rights-holder(s) directly, unless additional rights are indicated by a Creative Commons license in the record and/ or on the work itself. This Thesis has been accepted for inclusion in WVU Graduate Theses, Dissertations, and Problem Reports collection by an authorized administrator of The Research Repository @ WVU. For more information, please contact researchrepository@mail.wvu.edu. 


\title{
Organic Poultry Production \\ and \\ Forage Digestibility
}

\author{
Nancy P. Buchanan
}

\begin{abstract}
Thesis submitted to the Davis College of Agriculture, Forestry and Consumer Sciences at West Virginia University in partial fulfillment of the requirements for the degree of
\end{abstract}

\author{
Master of Science \\ in \\ Animal and Veterinary Sciences \\ Joseph S. Moritz, Ph.D., Chair \\ Eugene E. Felton, Ph.D. \\ Hillar Klandorf, Ph.D.
}

Division of Animal and Veterinary Sciences

\author{
Morgantown, West Virginia \\ 2005
}

Keywords: Nutrition, Organic/Free-Range Production, Non-Starch Polysaccharide Enzymes, Forage, $\mathrm{AME}_{n}, \mathrm{TME}_{\mathrm{n}}$, TAAD 


\section{ABSTRACT \\ Organic poultry production and forage digestibility}

Nancy P. Buchanan

The current experiments were conducted to evaluate organic poultry production and the digestibility of organic feeds and pasture forages. A performance study was conducted to determine the effect of exogenous non-starch polysaccharide (NSP) enzyme supplementation on the performance and carcass characteristics of organically-reared broiler chickens. The addition of an exogenous NSP enzyme cocktail improved the performance and carcass characteristics of organically-reared broilers given access to pasture only in spring months. Pasture forages may contribute digestible nutrients to poultry; however, this contribution has not been evaluated in past research. A digestibility study was conducted to determine the nitrogen-corrected apparent metabolizable energy $\left(\mathrm{AME}_{\mathrm{n}}\right)$ and nitrogen-corrected true metabolizable energy $\left(\mathrm{TME}_{\mathrm{n}}\right)$ of organic broiler diets and pasture forages. Additionally, the true amino acid digestibility (TAAD) of pasture forages was evaluated using poultry as the model. Poultry given access to pasture can meet a portion of their nutrient requirements through pasture access. 


\section{Acknowledgements}

This research would not be possible without the patience, continuing support, and encouragement of my major professor, advisor, and good friend, Dr. Joe Moritz. Thank you to my committee members Dr. Gene Felton and Dr. Hillar Klandorf for their guidance and advice. I cannot begin to describe my appreciation for everyone that has contributed to this research. Thank you Amy Parsons, Leah Merritt, Nicole Baker, John Hott, Sarah Cutlip, and all of the undergraduate students and staff that have contributed to my success. Special thanks to my parents and my brother for their continued support and confidence in my abilities and accomplishments. 
TABLE OF CONTENTS

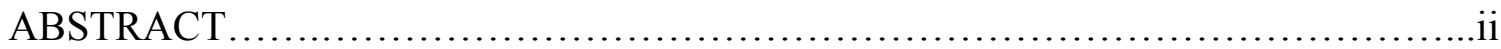

ACKNOWLEDGEMENTS........................................................

TABLE OF CONTENTS................................................................

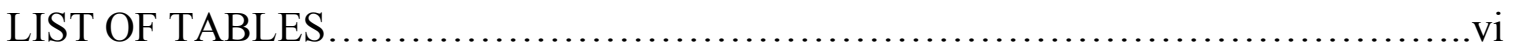

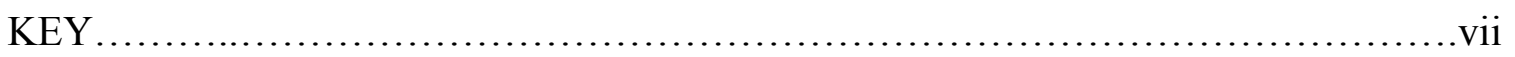

CHAPTER ONE- LITERATURE REVIEW ...........................................

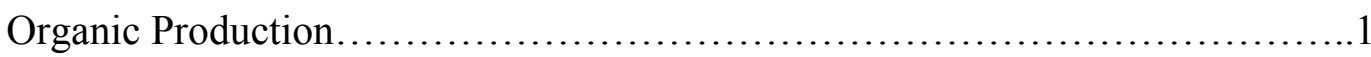

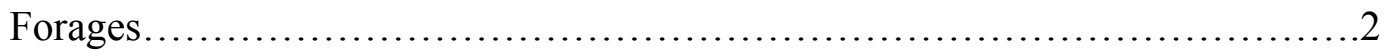

Plant Cell Wall Structure..........................................................

Non-Starch Polysaccharides.................................................

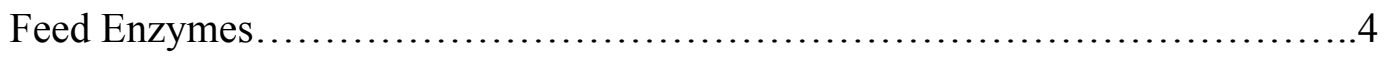

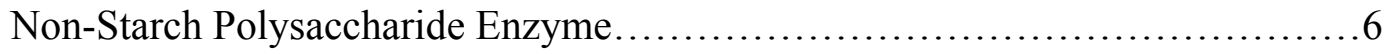

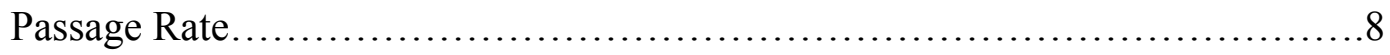

Energy Determination................................................ 10

Amino Acid Digestibility.................................................11

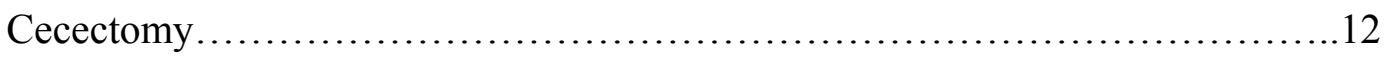

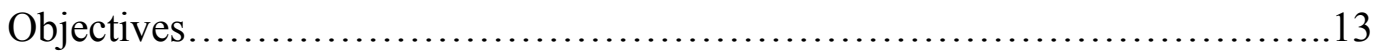

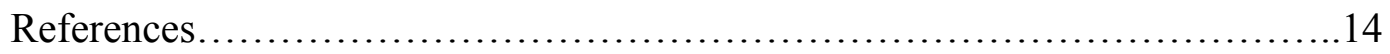

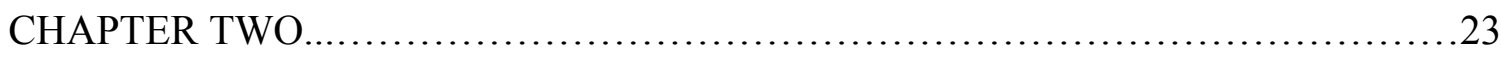

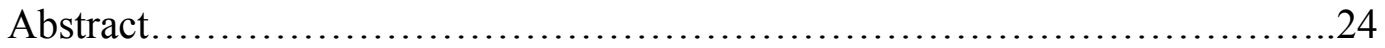

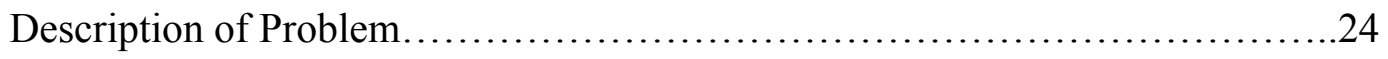

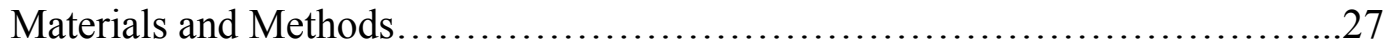


Statistical Analysis.................................................. 31

Results and Discussion................................................ 31

Conclusions and Applications........................................ 36

References........................................................... 37

Tables............................................................42

CHAPTER THREE.........................................................48

Abstract..................................................................... 49

Description of Problem..............................................50

Materials and Methods.................................................52

Statistical Analysis.................................................54

Results and Discussion...............................................55

Conclusions and Applications........................................58

References........................................................59

Tables..................................................................66

\section{APPENDICES}

I. Lignin and Non-starch Polysaccharide Components of Common Cereal Grains, Cereal By-products, and FiberRichMaterials.....................71

II. Composition and Properties of Non-starch Polysaccharide Enzyme..........72

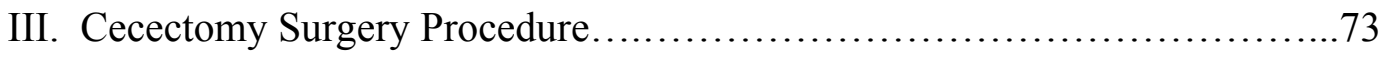

IV. West Virginia University Animal Care and Use Committee Protocol Statement \#03-0302 ................................................ 74

V. West Virginia University Animal Care and Use Committee Protocol

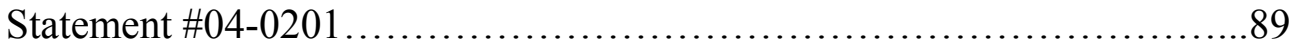




\section{LIST OF TABLES}

\section{CHAPTER TWO}

Table 1. Outside environmental conditions...............................42

Table 2. Diet formulation and nutrient parameters for organic diets............43

Table 3. Influence of enzyme inclusion and dietary energy restriction on

3-to-8-week broiler performance.........................44

Table 4. Influence of enzyme inclusion and dietary energy restriction on 3-to-8-week broiler carcass characteristics...................45

Table 5. Influence of enzyme inclusion and dietary energy restriction on passage time as determined by percent acid insoluble ash.........46

Table 6. Forage intake in treatment paddocks.............................47

\section{CHAPTER THREE}

Table 1. Diet formulation and nutrient parameters for organic diets...........66

Table 2. Diet formulation and nutrient parameters of conventional diets.......67

Table 3. Nitrogen-corrected apparent metabolizable energy and nitrogencorrected true metabolizable energy..........................68

Table 4. Nutrient composition of forage ................................69

Table 5. True amino acid digestibility of forage...........................70 
$\underline{\text { Key }}$

NSP $=$ non-starch polysaccharide

$\mathrm{AME}_{\mathrm{n}}=$ nitrogen corrected apparent metabolizable energy

$\mathrm{TME}_{\mathrm{n}}=$ nitrogen corrected true metabolizable energy

$\mathrm{TAAD}=$ true amino acid digestibility

$\mathrm{LWG}=$ live weight gain

$\mathrm{FI}=$ feed intake

$\mathrm{FE}=$ feed efficiency

$\mathrm{HCW}=$ hot carcass weight

$\mathrm{HGW}=$ hot gizzard weight

$\mathrm{GRH}=$ gizzard weight as a ratio of $\mathrm{HCW}$

$\mathrm{CCW}=$ chilled carcass weight

$\mathrm{CBW}=$ chilled breast weight (boneless/skinless)

$\mathrm{FPW}=$ fat pad weight

$\mathrm{FRH}=$ fat pad as a ratio of $\mathrm{HCW}$

$\mathrm{BPC}=$ breast weight as a percent of CCW (boneless/skinless) 


\section{LITERATURE REVIEW}

\section{ORGANIC PRODUCTION}

Consumers have become increasingly concerned with animal welfare issues and the composition of diets fed to production animals. In an attempt to address these concerns, organic poultry production has developed as an alternative to current conventional management practices. Federal regulation states that stocking densities utilized in organic production must allow for natural behavior and organic poultry must have access to the outdoors, shade, shelter, and dry bedding [1]. However, broilers may be hesitant to properly utilize outdoor enclosures. Past research has shown that fastgrowing strains of broilers given access to the outdoors will not take full advantage of enclosures due to a rapid growth rate and subsequent skeletal problems [2]. Therefore, it may be necessary to motivate poultry to utilize pasture enclosures.

Dawkins et al. found that commercial broilers are more likely to utilize outdoor enclosures when shade and shelter are provided in the form of trees and shrubs [3]. In addition, research has reported that broiler strain and feed composition determine how often broilers are observed outside [2]. Commercial broilers fed a restricted-intake diet will utilize outdoor enclosures more than broilers fed a diet ad libitum [4]. Scott et al. [5] and Castellini et al. [6] found that birds with access to outdoor enclosures had decreased incidence of fear and stress, respectively.

The use of growth promoters, antibiotics, coccidiostats, and animal by-products are prohibited in organic poultry feed [1]. Feed must be certified organic and fed from the second day of life. Moreover, the grains used to comprise a poultry ration must be certified organic [1]. Certified organic feed is expensive due to the high premiums 
required for organic grain [7]. In 1997, organic soybeans cost 50\% more than conventional soybeans and organic corn cost $73 \%$ more than conventional corn [8]. Today organic grains can cost over $300 \%$ more than conventional grains $[9,10]$ and premiums are projected to increase [7].

Organic poultry have access to nutrient sources not available to birds reared in a conventional setting. For example, organic poultry may utilize forage, insects, and annelids to meet their energy and amino acid requirements $[4,11,12]$. However, digestibility of these alternative nutrient sources for poultry is not known.

\section{FORAGES}

Forage may be viewed as an alternative nutrient source for organically-reared poultry. Grasses, such as Kentucky bluegrass and tall fescue, and legumes, such as red clover and white clover, are common in the eastern United States [13]. Poultry prefer pasture that is succulent and tender and past research has shown that white clover is the preferred pasture legume for poultry $[14,15]$. Additionally, research has found that laying hens, given access to early-growth Kentucky bluegrass and fed a corn-based diet, perform well and may require 20 percent less concentrate than hens raised in confinement [16].

\section{PLANT CELl WALl STRUCTURE}

In order for a plant to grow, the primary cell wall must be thin and extensible. Cellulose molecules covalently link to one another to form a ribbon-like structure. Bundles of long cellulose microfibrils are formed by hydrogen bonding between adjacent cellulose molecules. Furthermore, these cellulose microfibrils are cross-linked to one another by hydrogen-bonded glycan molecules. Glycans are a series of polysaccharides 
composed of a long linear backbone containing one type of sugar (glucose, xylose, or mannose) from which short side chains of other sugars protrude. These sugars are often insoluble in water and may be referred to as non-starch polysaccharides (NSPs). Examples include $\beta$-glucan, arabinoxylan, and mannan. The backbone and the side-chain sugars vary depending on the plant species and its stage of development. These bonds provide a configuration that is similar in structure to plywood and similar in tensile strength to steel [17].

Once maximum growth is achieved a rigid secondary cell wall is deposited in layers inside the primary cell wall [17]. Coniferyl, p-hydroxyphenyl, and sinapyl alcohols are arranged into an indigestible web-like structure to form lignin; the most common component of the secondary cell wall [18]. Unlike most other carbohydrate components of the plant cell wall, lignin is a structural polymer and is highly indigestible to both ruminants and monogastrics [18]. The structural portion of a plant is primarily composed of lignin. However, structure is also provided by cellulose, pectin, and NSPs. All of these entities have been identified as that contributing to digestibility problems [19].

\section{NON-STARCH POLYSACCHARIDES}

All grains currently fed to poultry contain various amounts of NSPs (Appendix I). However, two main types are currently of importance in poultry nutrition; ß-glucans (xyloglucans) and pentosans (arabinoxylans) [20]. These compounds are polymers of the monosaccharides glucose and xylose, respectively. Glycosidic bonds between the hemiacetal group of one sugar and the hydroxyl group of the other sugar join the monosaccharides into a linear chain that may contain side-chain linkages [20]. Henry 
[21] and Bach Knudsen [22] reported that the largest amount of $\beta$-glucans are found in barley and oats while the largest amount of pentosans are found in rye and wheat.

Oligosaccharides, sugars with two to ten simple sugars linked together, are prevalent in soybeans [23]. Over the entire length of the digestive tract $\beta$-glucans have been found to be least digestible and pentosans intermediate in digestibility [24]. Monogastrics have a limited ability to utilize some nutrients found in feed and forage due to the high level of NSPs $[25,26,27]$. Oats and barley contain a relatively consistent $ß(1 \rightarrow 4)$ backbone with or without $\beta(1 \rightarrow 3)$ glucan linkages [24]. The prevalence of the $\beta(1 \rightarrow 3)$ linkage prevents digestive enzymes from cleaving hydrogen bonds causing a decrease in digestibility of the nutrients found in these feedstuffs [28]. In contrast, pentosans found in rye and wheat are highly branched and vary considerably in structure [30]. Side chains consisting of one or more arabinose residues prohibit digestive enzymes from permeating the linear backbone [29]. These side chains have varying arabinose:xylose ratios and differ in degree of branching. Thus, different cultivars of wheat and rye vary greatly in their response to exogenous enzyme supplementation [30]. The digestion of all nutrients is adversely affected by consumption of NSPs due to an anti-nutritive factor [20, 24, 27, 31]. Leeson and Summers [20] reported that undigested NSPs bind large amounts of water resulting in a viscous digesta. This bolus of viscous feed reduces the permeability of enzymes to the digesta and results in a decrease in overall digestion $[30,32]$.

\section{FEED ENZYMES}

Various enzymes have been developed to aid in the digestion of the NSP fraction of feed [33]. Exogenous enzyme inclusion in the diet may aid in digestibility by disrupting cell walls and allowing better access of digestive enzymes to encapsulated 
nutrients [34]. The addition of exogenous enzymes cleaves the glycosidic bond of the unbranched $\beta$-glucans or pentosans. In addition, exogenous enzymes may aid in digestion when endogenous enzymes are overwhelmed [35]. However, the efficacy of enzyme supplementation is litigious.

Swine average daily gain and carcass weight has been significantly improved with the addition of a hemicellulase enzyme to a corn-soybean based diet [36, 37]. Moreover, it has been found that the addition of a pentosanase enzyme to a soybean based diet significantly improved AME and NSP digestion in growing broiler chickens [38]. Broiler performance improvements associated with enzyme supplementation have been reported by Hetland and Svihus [39] with addition of a $\beta$-glucanase/xylanase/protease enzyme cocktail to a wheat or naked oat based diet. Guenter [33] reported performance improvements with the addition of a cellulase enzyme to a barley or rye based diet. Additionally, Pettersson et al. [40] reported a significant improvement in broiler performance when a $\beta$-glucanase enzyme was added to a barley-based diet and when a pentosanase enzyme was added to a rye based diet.

Conversely, Kocher et al. [26] found that the inclusion of three different enzyme cocktails (cellulase//-glucanase/xylanase, hemicellulase/pentosanase/xylanase, and hemicellulase/pectinase/ $\beta$-glucanase) did not affect performance of broilers fed a $35 \%$ lupin diet compared to broilers fed the same diet with no enzyme supplementation. Supplementing a wheat-based diet with a $\beta$-glucanase enzyme has also been shown to not improve broiler performance when compared to the same diet without enzyme supplementation [41]. Moreover, Kocher et al. [23] reported that the addition of the industry suggested amount of a hemicellulase/pectinase// $/$-glucanase enzyme cocktail to a 
corn-soybean based diet did not affect variables such as broiler $\mathrm{AME}_{\mathrm{n}}$ and ileal protein digestibility; however, adding more than the suggested amount of enzyme did improve performance. These conflicting data suggest that the magnitude of performance and digestibility improvement is dependent upon two variables; 1) a dose response correlated to enzyme supplementation and 2) the type and concentration of soluble NSPs in the feedstuffs $[23,33]$.

\section{NON-STARCH POLYSACCHARIDE ENZYME (Appendix II)}

The NSP enzyme cocktail to be utilized in the proposed research is commercially available. The active enzyme is produced by submerged fermentation of Aspergillus aculeatus and the enzyme coating is synthetically produced using plant and mineral components. The enzyme cocktail is formulated to contain endo-1,3(4)- $\beta$-glucanase, pentosanase, hemicellulase, and pectic-substance hydrolyzing activities. It is intended for use in poultry, pigs, and other monogastric species fed diets containing soybeans, rapeseed, sunflower seeds, peas, maize, or sorghum.

\section{$\underline{\text { Cellulose }}$}

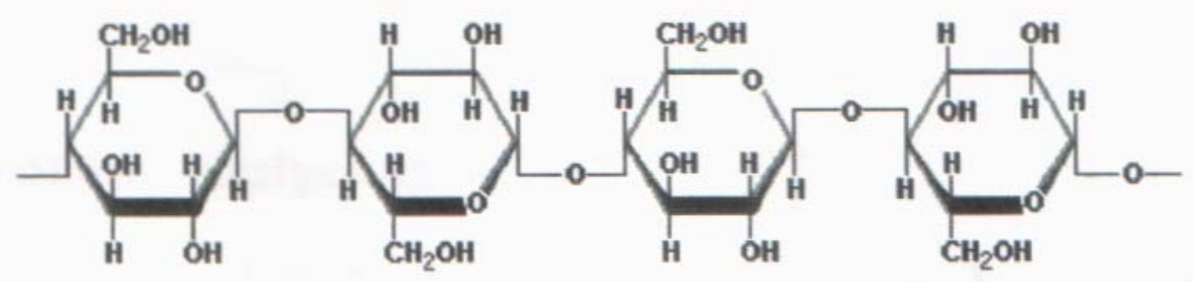




\section{$\beta$-glucan}

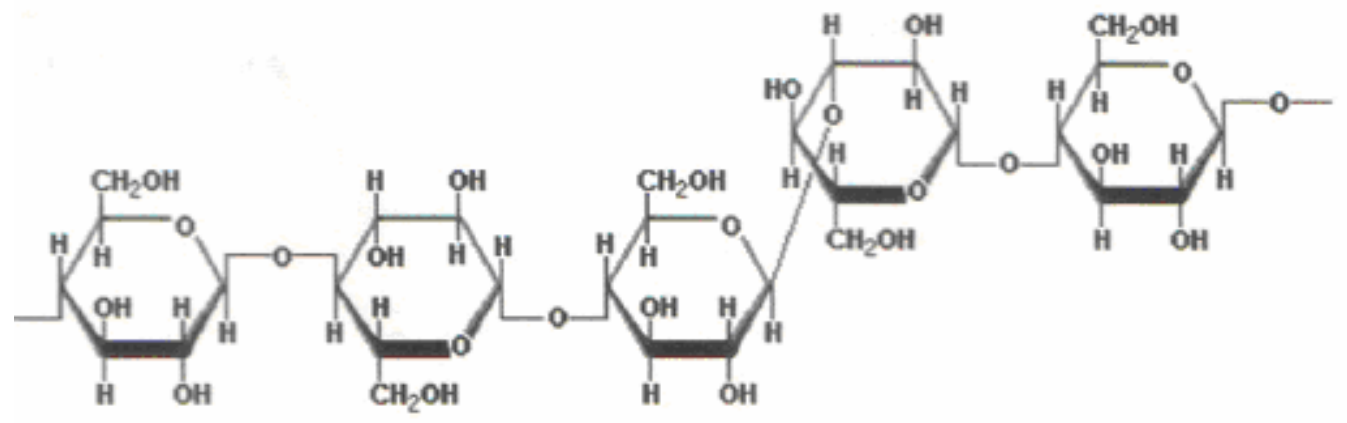

\section{$\underline{\text { Pentosan }}$}

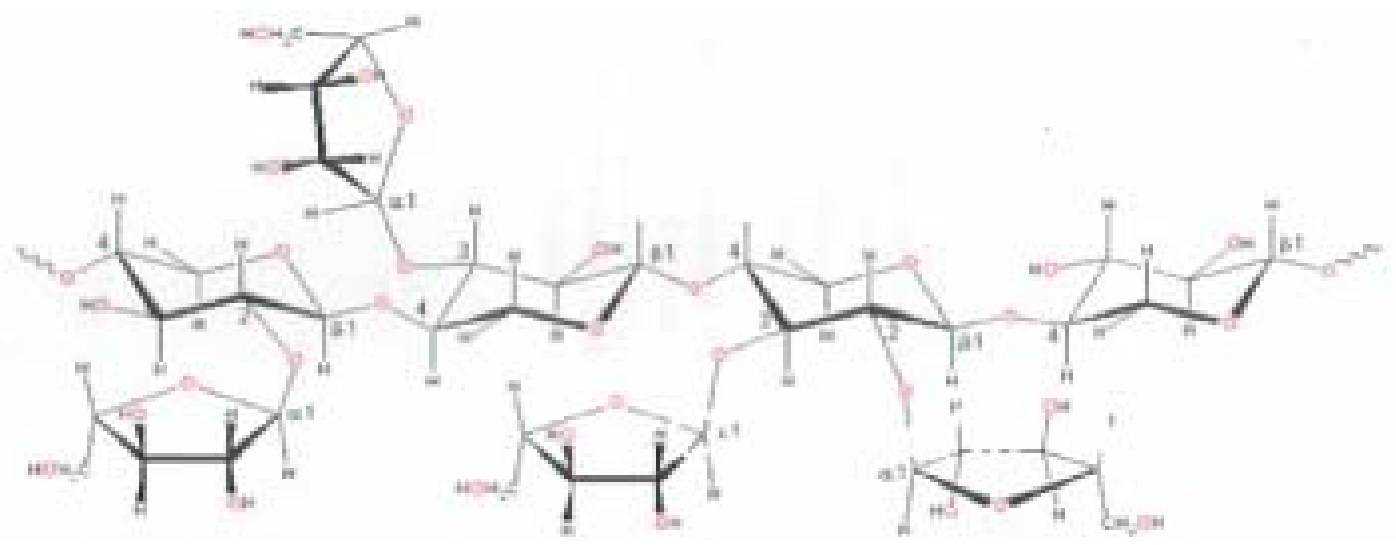

$\underline{\text { Hemicellulose (end-products of digestion) }}$

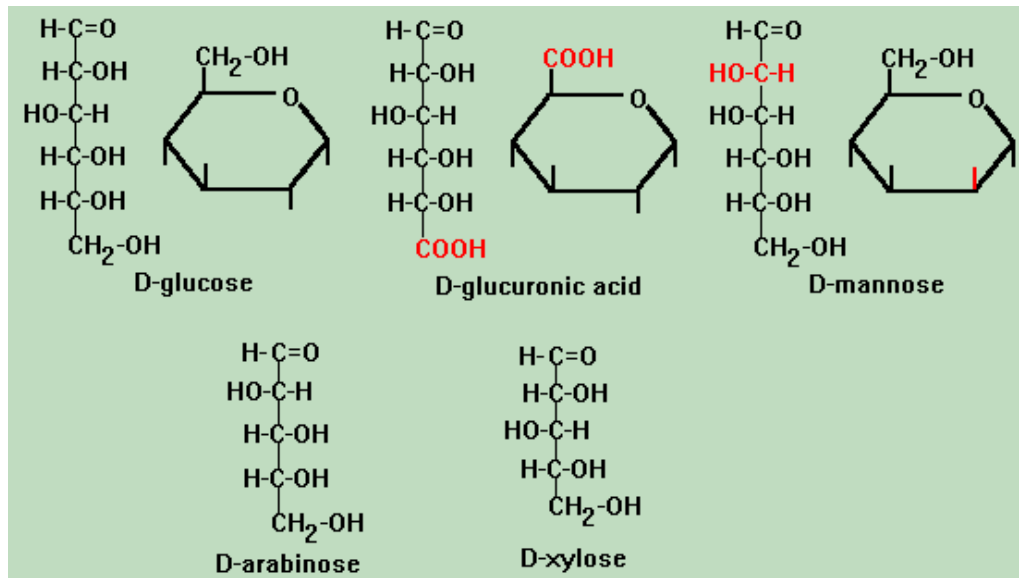




\section{$\underline{\text { Pectin }}$}

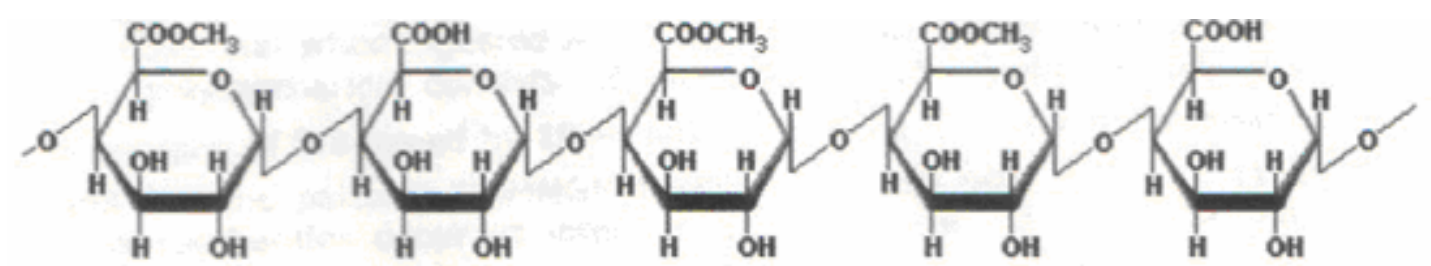

\section{PASSAGE RATE}

The rate that feed passes through the digestive tract of the chicken may influence the nutrition of the bird by 1) determining the length of time during which nutrients may be digested and absorbed, 2) determining the microbial population of the intestine and 3) limiting the daily feed intake [42]. If digesta markers are used, marked excreta will begin to appear 2-2.5 hours following intake and most marker will be excreted 12 hours postfeeding [42]. Composition of the diet can significantly affect feed passage rate.

Supplementing broiler diets with high levels of fat may significantly lengthen feed passage time for broiler chickens $[42,43,44]$. Additionally, variation in particle size and feed restriction may also affect the rate of feed passage in poultry. Hetland and Svihus [39] found a significant increase in feed passage time for broilers fed coarsely ground oats compared to finely ground oats. Washburn [45] has stated that feed restriction has no effect on feed passage time when compared to birds provided with ad libitum feed and that feed passage time is not correlated to feed conversion ratio.

As previously stated, feedstuffs containing large amounts of NSPs will imbibe water causing a bolus of feed to form. Consequently, this large bolus of feed results in the modification of feed passage time. However, the affect of NSPs on broiler passage time is controversial. Past research has shown that broiler diets high in NSPs result in longer feed passage time and a subsequent decrease in feed intake [46]. Insoluble fiber 
(NSPs and lignin) affects intestinal function by accumulating in the gizzard [47] and results in lengthened passage time of the fiber fraction compared to other feed components [48]. Olver and Jonker reported that feed passage time in the gizzard was lengthened when birds were fed whole grain subsequently resulting in an increased feed passage time across the entire digestive tract [49]. In contrast, Smiths and Annison theorized that insoluble fiber would decrease feed passage time due to an increase in digesta bulk [19]. This theory is also prevalent in human nutrition [50]. Moreover, Svihus et al. [51] and Moore [52] found no significant difference in feed passage time between broilers fed whole wheat and ground wheat and broilers fed feeds with varying chemical structures, respectively.

Despite controversy over the relationship between increased NSP content and lengthened feed passage time, the addition of an exogenous NSP enzyme into poultry diets tends to accelerate feed passage time. Almirall and Esteve-Garcia [48] and Salih et al. [53] found that the addition of an exogenous $\beta$-glucanase enzyme to a barley-based diet significantly shortened feed passage time likely due to a reduction in digesta viscosity. Sieo et al. reported that supplementing a barley-based diet with a $\beta$-glucanaseproducing Lactobacillus accelerated feed passage time and led to a decrease in pancreas, liver, duodenum, jejunum, ileum, ceca, and colon weights. In addition, jejunal villus height of chickens fed a diet supplemented with enzymes from transformed Lactobacillus strains were significantly higher than that of chickens fed diets with no enzyme supplementation [54]. This may result in an increase in feed efficiency for broilers fed diets containing beneficial exogenous enzymes. Furthermore, supplementing a rye-based diet with a xylanase enzyme accelerated feed passage time and increased digestibility of 
other nutrients in the diet $[44,55]$. However, it is important to note that in all instances gastrointestinal tract utilization was reduced with increased age of the bird.

\section{ENERGY DETERMINATION}

Various measurements are used to determine the amount of energy available to poultry. Accurate data on energy values of purified nutrients and crude feeding materials are necessary for quantitative studies in energy nutrition [56]. The poultry industry is continually expanding making it necessary to execute metabolism studies on improved and unconventional feed ingredients. Various methods of determining energy have been used in the past $[57,58]$. In 1946, an estimate of net energy using a carcass analysis technique was used to determine the net energy of many feedstuffs [59]. Hill and Anderson first reported on a procedure used to measure the metabolizable energy of a feedstuff by substituting the test ingredient into a semipurified diet [56]. Sibbald and Slinger modified this procedure by substituting the test feedstuff for all energy-yielding ingredients in the diet [60]. The amount of energy in the excreta was subtracted from the amount of energy in the feedstuff and referenced back to intake.

Hill and Anderson corrected all data for positive nitrogen retention because the extent of retention differs with age and species [56]. Slinger et al. reported that differences in requirements may be due to a number of factors including genetic variations in the ability to digest and absorb nutrients. For example, White Leghorn chicks have been shown to metabolize more energy per unit of feed than White Rock chicks; however, the authors state that correcting for nitrogen does little to improve ME values and the work involved is not justified [61]. Conversely, Potter suggested that a correction to zero nitrogen retention is necessary for reproducible results if $\mathrm{ME}$ is to be 
measured with birds of various ages because of differences in rates of protein accretion or protein catabolism [62]. Therefore, a nitrogen correction factor is essential if comparisons of ME values for the same ingredient with different animals are to be made. Theorizing that all protein tissue oxidized for energy purposes would yield uric acid and that $8.22 \mathrm{kcal}$ is the combustible energy value of uric acid per gram of nitrogen, a correction factor of $8.22 \mathrm{kcal} / \mathrm{g}$ can be utilized [56]. This method of energy determination is currently referred to as nitrogen corrected apparent metabolizable energy $\left(\mathrm{AME}_{\mathrm{n}}\right)$.

Currently, energy is measured using apparent metabolizable energy (AME) or true metabolizable energy (TME). $\mathrm{AME}$ or $\mathrm{AME}_{\mathrm{n}}$ is defined by the $\mathrm{NRC}$ as the gross energy of the feed consumed minus the gross energy of the excreta of feed origin [63]. Sibbald reported that the energy components of feed are not all directly of dietary origin [64]. Therefore, a correction factor is made to account for any endogenous excretion from cell sloughing, protein degradation, or microbial loss. A nitrogen correction is often applied to TME values to obtain a $\mathrm{TME}_{\mathrm{n}}$ value. TME values (or AME values) can be calculated through measurement of feed intake and excreta output, or by determining the ratio of dry matter intake or output through use of an inert dietary marker, such as chromic oxide [63].

\section{IX: AMINO ACID DIGESTIBILITY}

Dietary requirements for protein are actually requirements for the amino acids contained in the dietary protein. Amino acid requirements vary greatly depending on productive state, environmental conditions, breed, and strain of the bird [63]. Amino acid digestibility is determined in a similar manner as AME or TME. The concentration of 
amino acids in the excreta is subtracted from the concentration of amino acids in the feedstuffs and related back to the amount of amino acid intake. Sibbald estimated the loss of endogenous amino acids through the use of starved birds or birds fed a proteinfree diet [65].

Methods used to estimate amino acid digestibility vary. Papadopoulos [66] and Low [67] determined digestibility in vivo by sampling ileal digesta. Whitacre and Tanner preferred this method because the modifying action of the hindgut microflora on protein composition is avoided [68]. However, Webb argued that amino acids are not absorbed in the hindgut of the chicken and that collecting ileal digesta is not necessary [69]. The amount of amino acids in the feedstuff also appears to affect amino acid digestibility. Many essential amino acids in common ingredients such as corn and soybean meal are digested with about $90 \%$ efficiency [70]. However, Kadim et al. reported that for rations containing lower concentrations of protein and amino acids, correction for endogenous losses led to amino acid digestibility values exceeding $100 \%$ [71].

\section{X: CECECTOMY (Appendix III and V)}

Another complexity in determining digestibility is the role of the ceca. The ceca provide a habitat for numerous microorganisms and various species of protozoa and parasites $[72,73]$. It is unclear what role the active ceca play in a bird's nutrition. Digesta may enter the ceca where proteins can be digested and amino acids can be degraded [71]. If cecectomized birds are used in a digestibility assay, there are minor effects for cereals and most vegetable proteins, although quite large differences are seen with animal proteins [74]. However, Mangold reported that the ceca may be a major site 
of crude fiber digestion and that an avian species with a large ceca (chickens) has greater fiber digestion than an avian species with a rudimentary ceca (pigeons) [75].

\section{OBJECTIVES}

The objective of the first study was to increase the performance and carcass characteristics of organically-reared broiler chickens by incorporating an exogenous NSP enzyme. The hypothesis was based on the composition of forages and the success of enzyme supplementation in conventional poultry production. Additionally, a second study was conducted that aimed to quantify the $\mathrm{AME}_{\mathrm{n}}, \mathrm{TME}_{\mathrm{n}}$, and TAAD of forage feedstuffs. 


\section{REFERENCES}

1. National Organic Program Standards. Agricultural Marketing Service, United States Department of Agriculture. 34 C.F.R. § 106.41(b) (2003).

2. Nielsen, B.L., M.G. Thomsen, P. Sorensen, and J.F. Young, 2003. Feed and strain effects on the use of outdoor areas by broilers. Brit. Poult. Sci., 44:161-169.

3. Dawkins, M.S., P.A. Cook, M.J. Whittingham, K.A. Mansell, and A.E. Harper, 2003. What makes free-range chickens range? In situ measurement of habitat preference. An. Behavior, 66:151-160.

4. Moritz, J.S., A.S. Parsons, N.P. Buchanan, N.J. Baker, J.Jaczynski, O.J. Gekara, and W.B. Bryan, 2005. Synthetic Methionine and feed restriction effects on performance and meat quality of organically reared broiler chickens. J. Appl. Poult. Res., $14: 521-535$.

5. Scott, G.B., B.J. Connell, and N.R. Lambe, 1998. The fear levels after transport of hens from cages and a free-range system. Poult. Sci. 77:62-66.

6. Castellini, C., C. Mugnai, and A. Dal Bosco, 2002. Effect of organic production system on broiler carcass and meat quality. Meat. Sci. 60:219-225.

7. Dobbs, T.L. and J.D. Smolik, 1999. Productivity and profitability of conventional and alternative farming systems: A long-term on-farm paired comparison. J. Sustain. Agric., 9:63-79.

8. Welsh, R., 1999. The economics of organic grain and soybean production in the midwestern United States. Policy Studies Report No. 13. Henry A. Wallace Institute for Alternative Agriculture. Greenbelt, MD.

9. Grain prices for Nature's Best Organic Feeds, Kraemer, PA. Summer 2005. 
10. Anonymous, 2005. Ingredient Market, Feedstuffs 77(17):26.

11. Clark, M.S. and S.H. Gage, 1996. Effects of free-range chickens and geese on insect pests and weeds in an agroecosystem. Amer. J. Alternative Agric. 11:39-47.

12. Clark, M.S., S.H. Gage, L.B. DeLind, and M. Lennington, 1995.

Compatibility of domestic birds with a nonchemical agroecosystem. Amer. J. Alternative Agric. 10:114-121.

13. Barnes, R.F., D.A. Miller, and C.J. Nelson, 1995. Environmental and Physiological Aspects of Forage Management. Forages: Volume 1 An Introduction to Grassland Agriculture, Published by Iowa State University Press, Ames, IA, pp. 56-57.

14. Kennard, D.C., L.E. Thatcher, and V.D. Chamberlain, 1949. Ohio Farm and Home Res. Nos. 246, 257.

15. Morrison, F.B., 1957. General Problems in Poultry Production. Feeds and Feeding: A Handbook for the Student and Stockman, Published by The Morrison Publishing Company, Ithaca, NY, p. 958.

16. Buckner, G.D., W.M. Insko, Jr., and A.H. Henry, 1945. Influences of spring bluegrass and mature bluegrass on laying hens and on the eggs produced. Poult. Sci., 24:446-450.

17. Alberts, B., A. Johnson, J. Lewis, M. Raff, K. Roberts, and P. Walter, 2002. Cells in Their Social Context. Molecular Biology of the Cell, Published by Garland Science, New York, NY, p. 1118-1124.

18. Moore, K.J., and H-J. G. Jung, 2001. Lignin and fiber digestion, J. Range Manage., 54:420-430. 
19. Smiths, C.H.M., and G. Annison, 1996. Non-starch plant polysaccharides in broiler nutrition- towards a physiologically valid approach to their determination. World's Poult. Sci., 42:203-221.

20. Leeson, S. and J.D. Summers, 2001. Digestion and nutrient availability. Scott's Nutrition of the Chicken, Published by University Books, Guelph, Ontario, p. 77.

21. Henry, R.J., 1985. A comparison of the non-starch carbohydrates in cereal grain. J. Sci. Food Agric., 36:1243-1253.

22. Bach Knudsen, K.E., 1997. Carbohydrate and lignin contents of plant materials used in animal feeding. An. Feed Sci. Tech., 67:319-338.

23. Kocher, A., M. Choct, M.D. Porter, and J. Broz, 2002. Effects of feed enzymes on nutritive value of soyabean meal fed to broilers. Brit. Poult. Sci., 43:54-63.

24. Iji, P.A., 1999. The impact of cereal non-starch polysaccharides on intestinal development and function in broiler chickens. World's Poult. Sci., 55:375-387.

25. Leeson, S. and J.D. Summers, 2001. Digestion and nutrient availability. Scott's Nutrition of the Chicken, Published by University Books, Guelph, Ontario, p. 5.

26. Kocher, A., M. Choct, M.D. Porter, and J. Broz, 2002. Effects of food enzymes on utilization of lupin carbohydrates by broilers. Br. Poult. Sci., 41: 75-82.

27. Choct, M., R.J. Hughes, J. Wang, M.R. Bedford, A.J. Morgan, and G. Annison, 1996. Increased small intestinal fermentation is partly responsible for the antinutritive activity of non-starch polysaccharides in chickens. Br. Poult. Sci., 37: 609-621.

28. Dahle, H.K., E. Eikum, and K.N. Lilleeng, 1992. Glucanases in feed products. Norsk Landbruksforsking, 6:1-5. 
29. Gruppen, H., F.J.M. Kormelink, and A.G.J. Voragen, 1993. Waterunextractable cell-wall material from wheat-flour. 3. A structural model for arabinoxylans. J. of Cereal Sci., 18:111-128.

30. Chesson, A., 2001. Non-starch polysaccharide degrading enzymes in poultry diets: influence of ingredients on the selection of activities. World's Poult. Sci., 57:251263.

31. Choct, M. and G. Annison, 1992. Anti-nutritive effect of wheat pentosans in broiler chickens: roles of viscosity and gut microflora. Brit. Poult. Sci., 33:821-834.

32. Bedford, M.R., 1995. Mechanism of action and potential environmental benefits from the use of feed enzymes. An. Feed Sci. and Tech., 53:145-155.

33. Guenter, W., 1993. Impact of feed enzymes on nutrient utilization of ingredients in growing poultry. J. Appl. Poultry Res, 2:82-84.

34. Campbell, G.L. and M.R. Bedford, 1992. Enzyme applications for monogastric feeds. A review. Can. J. Anim. Sci., 42:449-466.

35. Jeroch, H. and S. Danicke, 1995. Barley in poultry feeding. A review. World's Poult. Sci., 51:271-291.

36. Pettey, L.A., S.D. Carter, B.W. Senne, and J.A. Shriver, 1999. Effects of Hemicell $^{\circledR}$ addition to nursery diets on growth performance of weanling pigs. Oklahoma State University Animal Science Research Report, 273-279.

37. Pettey, L.A., S.D. Carter, B.W. Senne, and J.A. Shriver, 2000. Effects of Hemicell $^{\circledR}$ addition to corn-soybean meal diets on growth performance, carcass traits, and apparent nutrient digestibility in growing-finishing pigs. Oklahoma State University Animal Science Research Report, 117-122. 
38. Fengler, A.I. and R.R. Marquardt, 1998. Water-soluble pentosans from rye. II. Effects of rate of dialysis on the retention of nutrients by the chick. Cereal Chem., 65:298-302.

39. Hetland, H. and B. Svihus, 2001. Effect of oat hulls on performance, gut capacity and feed passage time in broiler chickens. Br. Poult. Sci., 42:354-361.

40. Pettersson, D., H. Graham, and P. Aman, 1990. Enzyme supplementation of broiler chicken diets based on cereals with endosperm cell walls rich in arabinoxylans or mixed-linked $\beta$-glucans. Anim. Prod., 51:201-207.

41. Edney, M.J., G.L. Campbell, and H.L. Classen, 1989. The effect of $\beta$ glucanase supplementation on nutrient digestibility and growth in broilers given diets containing barley, oat groats or wheat. Anim. Feed Sci. Technol., 25:193-200.

42. Tuckey, R., B.E. March, and J. Biely, 1958. Diet and the rate of food passage in the growing chick. Poult. Sci., 37:786-792.

43. Mateos, G.G., J.L. Sell, and J.A. Eastwood, 1982. Rate of food passage (transit time) as influenced by level of supplemental fat. Poult. Sci., 61:94-100.

44. Danicke, S., O. Simon, H. Jeroch, and M. Bedford, 1997. Interactions between dietary fat type and xylanase supplementation when rye-based diets are fed to broiler chickens. 1. Physio-chemcial chyme features. Brit. Poult. Sci., 38:537-545.

45. Washburn, K.W., 1991. Efficiency of feed utilization and rate of feed passage through the digestive system. Poult. Sci., 70:447-452.

46. Langhout, D.J., 1998. The role of intestinal flora as affected by non-starch polysaccharides in broiler chicks. Ph.D Thesis, Wageningen Agricultural University, Wageningen. The Netherlands. p. 162. 
47. Hetland, H., M. Choct, and B. Svihus, 2004. Role of insoluble non-starch polysaccharides in poultry nutrition. World's Poult. Sci., 60:415-422.

48. Almirall, M. and E. Esteve-Garcia, 1994. Rate of passage of barley diets with chromium oxide: Influence of age and poultry strain and effect of $\beta$-glucanase supplementation. Poult. Sci., 73:1433-1440.

49. Olver, M.D., and A. Jonker, 1997. Effect of choice feeding on the performance of broilers. Brit. Poult. Sci., 38:571-576.

50. Hoppert, C.A., and A.J. Clark, 1945. Digestibility and effect on laxation of crude fiber and cellulose in certain common foods. J. Am. Diet. Assoc., 21:157.

51. Svihus, B., H. Hetland, M. Choct, and F. Sundby. Passage rate through the anterior digestive tract of broiler chickens fed on diets with ground and whole wheat. Brit. Poult. Sci., 43:662-668.

52. Moore, S.J., 1999. Food breakdown in the avain herbivore; who needs teeth? Austr. J. of Zoo., 47:625-632.

53. Salih, M.E., H.L. Classen, and G.L. Campbell, 1991. Response of chickens fed on hull-less barley to dietary $\beta$-glucanase at different ages. Anim. Feed Sci. Technol., $33: 139-149$.

54. Sieo, C.C., N. Abdullah, W.S. Tan, and Y.W. Ho, 2005. Influence of $\beta$ glucanase-producing Lactobacillus strains on intestinal characteristics and feed passage rate of broiler chickens. Poult. Sci., 84:734-741.

55. Bedford, M.R., and H.L. Classen, 1992. Reduction of intestinal viscosity through manipulation of dietary rye and pentosanase concentration is effected through changes in the carbohydrate composition of the intestinal aqueous phase and results in 
improved growth rate and food conversion efficiency of broiler chicks. J. of Nutr. 122:560-569.

56. Hill, F.W. and D.L. Anderson, 1958. Comparison of metabolizable energy and productive energy determinations with growing chicks. J. of Nutr., 64:587-603.

57. Fraps, G.S., E.C. Carlyle, and J.F. Fudge, 1940. Metabolizable energy of some chickens foods. Texas Agr. Expt. Station Bull. 589.

58. Carpenter, K.J. and K.M. Clagg, 1956. The metabolizable energy of poultry feeding stuffs in relation to their chemical composition. J. Sci. Food Agric., 7:45-51.

59. Fraps, G.S., 1946. Digestibility of feeds and human foods by chickens. Texas Agr. Expt. Station Bull. 658.

60. Sibbald, I.R. and S.J. Slinger, 1963. A biological assay of ME in poultry feed ingredients together with findings which demonstrate some of the problems associated with the evaluation of fats. Poult. Sci., 42:313-325.

61. Slinger, S.J., I.R. Sibbald, and W.F. Pepper, 1964. The relative abilities of two breeds of chickens and two varities of turkeys to metabolize dietary energy and dietary nitrogen. Poult. Sci., 43:329-333.

62. Potter, L.M., 1972. The precision of measuring metabolizable energy in poultry feedstuffs. Feedstuffs, 44:28.

63. National Research Council, 1994. Nutrient Requirements of Poultry. $9^{\text {th }}$ rev. ed. National Academy Press, Washington, DC.

64. Sibbald, I.R., 1980. Metabolizable energy evaluation of poultry diets. In: Recent Advances in Animal Nutrition, W. Haresign and D. Lewis, eds. London: Butterworth. 
65. Sibbald, I.R., 1987. Estimation of bioavailable amino acids in feedingstuffs for poultry and pigs: a review with emphasis on balance experiments. Can. J. of An. Sci., 67:221-330.

66. Papadopoulos, M.C., 1985. Estimations of amino acid digestibility and availability in feedstuffs for poultry. World's Poult. Sci., 41:64-71.

67. Low, A.G., 1990. Protein evaluation in pigs and poultry. In: Feedstuff Evaluation, J. Wiseman and D.J.A. Cole, eds. London: Butterworth.

68. Whitacre, M.E. and H. Tanner, 1989. Methods of determining the bioavailability of amino acids for poultry, In: Absorption of Utilization of Amino Acids, Vol. III, M. Friedman, ed. Boca Raton, FL: CRC Press.

69. Webb, K.E., 1990. Intestinal absorption of protein hydrolysis products: a review. J. An. Sci., 6:3011-3022.

70. Leeson, S. and J.D. Summers, 2001. Digestion and nutrient availability. Scott's Nutrition of the Chicken, Published by University Books, Guelph, Ontario, p. 131-133.

71. Kadim, I.T., P.J. Moughan, and V. Ravinidran, 2002. Ileal amino acid digestibility assay for the growing meat chicken- comparison of ileal and excreta amino acid digestibility in the chicken. Brit. Poult. Sci., 44:588-597.

72. Barnes, E.M., G.C. Mead, D.A. Barnum, and E.G. Harry, 1972. The intestinal flora of the chicken in the period 2 to 6 weeks of age, with particular reference to the anaerobic bacteria. Brit. Poult. Sci., 13:311-326.

73. Compton, D.W.T. and M.C. Nesheim, 1976. Host-parasite relationships in the alimentary tract of domestic birds. Advances in Parasitology, 14:95-194. 
74. Green, S. and T. Kiener, 1989. Digestibilities of nitrogen and amino acids in soybean, sunflower meal and rapeseed meals measured with pigs and poultry. Anim. Prod., 48:157-179.

75. Mangold, E, 1934. The digestion and utilization of crude fiber. Nutr. Abst. Rev., 3:647. 


\title{
THE EFFECTS OF NON-STARCH POLYSACCHARIDE ENZYME ADDITION AND DIETARY ENERGY RESTRICTION ON PERFORMANCE AND CARCASS QUALITY OF ORGANIC BROILER CHICKENS
}

\author{
N.P. Buchanan, L.B. Merritt, A.S. Parsons, G.E. Seidel, W.B. Bryan, and J.S. Moritz \\ Division of Animal and Veterinary Science \\ West Virginia University, Morgantown, WV 26506 \\ Phone: 304-293-2631 ext. 4446 \\ nbuchana@mix.wvu.edu
}

\begin{abstract}
Key words: non-starch polysaccharides, forage utilization, broiler production, organic production, energy variation

Running Title: FEEDING BROILERS A NON-STARCH POLYSACCHARIDE ENZYME AND A LOW ENERGY DIET
\end{abstract}

Primary Audience: organic/free-range producers, nutritionists, broiler producers, researchers 


\section{Abstract}

Feed constitutes a substantial cost in organic production. Organic poultry may have access to pasture; a nutrient source that has the potential to curtail feed costs. Past research has demonstrated that feed restriction will motivate broilers to forage. Incorporating a non-starch polysaccharide (NSP) enzyme may enable broilers to better utilize nutrients found in forage. The objective of the current study was to decrease feed costs by increasing forage utilization through 1) the use of dietary energy restriction and 2) the incorporation of an exogenous NSP enzyme. The experiment was conducted during the 3-to-8-week growing phase in spring and summer months on broilers with and without pasture access. An energy x enzyme x pasture access effect $(\mathrm{P}=0.0064)$ was observed for live weight gain (LWG). Broilers given no pasture access had higher LWG compared to broilers given pasture access. In addition, consumption of normal energy diets improved LWG compared to low energy diets, regardless of pasture access. However, enzyme inclusion increased gain only when broilers were given access to pasture and fed the normal energy diet. An enzyme x season effect was also observed with broilers given enzyme in spring months exhibiting a higher LWG $(\mathrm{P}=0.001)$ and larger chilled carcass weight $(\mathrm{CCW})(\mathrm{P}=0.0193)$ than broilers given enzyme in summer months. Additionally, feed efficiency $(\mathrm{FE})$ improved $(\mathrm{P}=0.0009)$ for broilers reared in spring months compared to broilers reared in summer months. Forage intake was not affected by dietary energy or enzyme inclusion.

\section{Description of Problem}

The American public has become increasingly concerned with management practices and the composition of diets fed to production animals. In accordance with the 
demand for an increase in animal welfare, organic poultry production has become a fast growing segment of American agriculture. Organic poultry production provides consumers a product derived from organically certified grain that is free of antimicrobial growth promoters. Organic poultry producers supply only $1 \%$ of the poultry market in the United States, yet the demand for organic poultry products exceeds the supply [1].

Organic poultry production offers an economic opportunity for integrated companies looking for a niche market and family farms looking to supplement existing income. Land and husbandry costs are a small investment. However, feed is a substantial cost in production. The price of organic feed may be twice that of conventional feed due to the premiums required for organically certified grain.

Little is known about the nutrient requirements of organic poultry. Current diets are formulated to meet or exceed National Research Council (NRC) recommendations for poultry that are reared in a conventional setting. However, organic broilers may have access to pasture; a nutrient source that has not been evaluated for use in poultry production. Thus, it may be plausible to address animal welfare concerns and reduce feed costs by maximizing the use of pasture.

In some free-range and organic production settings, birds may seldom leave the house [2]. This becomes a concern because the animals do not properly utilize outdoor enclosures, leading to a false consumer perception. Nielsen et al. found that fast-growing commercial strains of birds given access to the outdoors will not take full advantage of pasture access due to a rapid growth rate and the subsequent correlation to impaired mobility [3]. In order to maximize pasture use, it is imperative that birds be motivated to spend time outdoors. Restrictive feeding may motivate broilers to meet nutrient 
requirements through foraging. A commercial strain of broilers restricted to $50 \%$ intake of an ad libitum pair-fed group has been shown to consume significantly more forage [4]. Thus, by providing a limited amount of feed, or perhaps reducing nutrient density, a producer may have the ability to motivate broilers to maximize forage intake.

Feed costs may be offset by increasing forage intake and improving forage digestibility. Nutrient availability of forage may be increased through the incorporation of feed enzymes. Forage is a fiber based energy source consisting of assorted non-starch polysaccharides (NSP). However, NSP levels vary depending on forage type, stage of growth, and season [5]. It has been well documented that monogastrics have a limited ability to utilize NSPs as a nutrient source $[6,7,8]$. In addition, NSPs may play an antinutritive role; adversely affecting digestion of other nutrients by imbibing water and causing feed to form a bolus that may reduce exposure to digestive enzymes [7, 9]. Moreover, increased consumption of NSPs has been linked to management problems involving increased stickiness of excreta and increased litter moisture $[6,10]$.

Broiler chickens do not produce endogenous enzymes that aid in NSP digestion. Thus, they rely on acid digestion in the proventriculus and microbial degradation in the ceca and large intestine [9]. Digestion of NSPs can range from 21.9\% in wheat diets to $13 \%$ in lupin diets without enzyme supplementation [11]. The effectiveness of exogenous NSP enzymes in monogastric diets has been controversial. Past research has shown that enzyme inclusion in a variety of poultry rations has no effect on performance or digestibility variables $[6,12,13]$. However, other studies report improved performance and digestiblity $[8,14,15,16]$. Research on NSP enzyme supplementation associated with forage digestibility in poultry does not exist. The objectives of this study 
were to reduce feed costs by increasing forage utilization via the use of a low energy diet and to increase nutrient digestibility of forage through the incorporation of an exogenous enzyme cocktail containing ß-glucanase, pentosanase, and hemicellulase hydrolyzing activities.

\section{Materials and Methods}

\section{Experiment 1}

Five hundred day-old Ross 308x344 broilers [17] of mixed sex were obtained from a commercial hatchery. All broilers were reared during the starter phase in floor pens located in a cross-ventilated negative pressure house using forced-air brooders. Broilers were provided with feed and water, supplied through feed pans and nipple drinkers, ad libitum. The temperature of the room was maintained at $35^{\circ} \mathrm{C}\left(90^{\circ} \mathrm{F}\right)$ and decreased to $22^{\circ} \mathrm{C}\left(70^{\circ} \mathrm{F}\right)$ during the $0-2$ week period. One week prior to outdoor placement (2-3 week period), temperature was decreased so that indoor temperature was comparable to outdoor temperature in order to acclimate broilers (Table 1). Broilers were fed a certified organic starter diet during the 0-to-3 week period (Table 2). The diet met or exceeded NRC recommendations [18].

On day 21, 300 birds were randomly selected and transported to the West Virginia University organic farm [19]. Birds were assigned at random to one of five $3.05 \mathrm{~m} \mathrm{x}$ $3.05 \mathrm{~m}(10 \mathrm{ft} \times 10 \mathrm{ft})$ poultry houses utilizing natural ventilation. Each house was divided into four equally sized pens that contained 15 birds at a stocking density of $1.5 \mathrm{ft}^{2} / \mathrm{bird}$. Each pen was equipped with fresh wood shavings, a Kuhl ${ }^{\circledR}$ feed pan and hopper, and a five-gallon water fount. All four pens within a single house had access to individual $6.10 \mathrm{~m} \times 9.15 \mathrm{~m}$ (20ft x 30ft) outdoor paddocks and unlimited forage; including Kentucky 
bluegrass, white clover, red clover and tall fescue. Broilers had access to pasture throughout all daylight hours (0800-2000) and were confined in the house throughout the night.

An energy level x NSP enzyme inclusion factorial design was utilized to provide a total of four dietary treatments (Normal Energy/No Enzyme (NOR/NE), Normal Energy/Enzyme (NOR/E), Low Energy/No Enzyme (LOW/NE), and Low Energy/Enzyme (LOW/E)) (Table 2). The normal energy (NOR) diet consisted of an organically certified grower diet that met NRC 3-to-6 week nutritional recommendations [18] with the exception of methionine. Past research has shown that birds given access to pasture may, in part, compensate for small deficiencies in methionine through pasture access [4]. Hence, diets excluded synthetic methionine and were slightly deficient in methionine according to NRC recommendations (Table 2). The low energy (LOW) diet was similarly formulated with the exception of a $7 \%$ energy reduction obtained by the addition of washed builder's sand at the expense of corn and soybean [20] (Table 2). Treatments consisted of the two aforementioned diets with or without the addition of a commercially available NSP enzyme cocktail at an inclusion level of $1 \mathrm{~kg} / \mathrm{ton}$. The enzyme cocktail was derived from the fermentation of Aspergillus aculeatus and contained $\beta$-glucanase, pentosanase, and hemicellulase hydrolysis activities [21]. The broilers fed LOW diets were pair-fed according to the previous day ad libitum consumption of broilers fed NOR energy diets. Pair feeding was performed daily to standardize feed intake and to conclude that treatment differences were due to the variation in dietary energy. 
Broilers without pasture access (negative control) were reared in floor pens at the West Virginia University poultry farm. The negative control broilers were fed the same dietary treatments as broilers with pasture access. Water was provided for ad libitum consumption through nipple drinkers and pair-feeding was utilized. Each negative control treatment was replicated in five pens containing $10 \mathrm{birds} / \mathrm{pen}\left(1.5 \mathrm{ft}^{2} / \mathrm{bird}\right)$. Lighting and temperature were controlled within the constraints of management equipment to mimic the outdoor conditions.

Live weight gain (LWG), feed intake (FI), feed efficiency (FE), forage intake, and percent mortality were determined from 21-to-38-days, 38-to-56-days, and the entire 21to-56-day experimental period. Grass samples were collected in each paddock using the procedure outline by Rayburn and Rayburn [22]. Feed and grass samples were freezedried [23], ground to $1 \mathrm{~mm} \mathrm{[24],} \mathrm{and} \mathrm{analyzed} \mathrm{for} \mathrm{gross} \mathrm{energy} \mathrm{[25],} \mathrm{nitrogen} \mathrm{[26]} \mathrm{and}$ amino acid content [27].

On day 57, all broilers were processed at the West Virginia University pilot processing plant. Four broilers ( 2 males and 2 females) were selected from each pen within all houses and from each pen in the negative control room. Broilers were selected based on their representation of the mean pen weight. Hot carcass weight (HCW), hot gizzard weight (HGW), hot fat pad weight (HFW), chilled carcass weight (CCW), and chilled breast weight (CBW) data were obtained. The study was conducted in spring months and then repeated in summer months to assess season effects. All animals were reared according to protocols established by the West Virginia University Animal Care and Use Committee - ACUC \# 03-0302 (Appendix IV). 


\section{Experiment 2}

A feed passage time study was performed to assess possible passage time variation in diets that differed in energy and composition. Sixty day-old Ross 308x344 broilers [17] of mixed sex were obtained from a commercial hatchery. All broilers were reared during the starter phase in a manner similar to Experiment 1 with the exception of brooding temperature. Over a three week period, temperature was regulated thermostatically by beginning chicks at $35^{\circ} \mathrm{C}\left(90^{\circ} \mathrm{F}\right)$ and decreasing temperature to $22^{\circ} \mathrm{C}$ $\left(70^{\circ} \mathrm{F}\right)$. On day 21 , broilers were transferred to $30.48 \mathrm{~cm} \times 50.80 \mathrm{~cm}(12 \mathrm{in} \times 20 \mathrm{in})$ raised wire cages located in a cross-ventilated negative pressure room. Three broilers were place in each cage that contained nipple drinkers and an external feed trough.

The organic grower diets (Table 2) utilized in Experiment 1 were randomly assigned to cages within each of four blocks. Feed and water were provided ad libitum during a seven-day adaptation period and fecal samples were collected to determine percent acid insoluble ash (AIA) from unmarked diets. At the conclusion of the adaptation period (day 28), feed was restricted for 24 hours. Broilers were then fed $100 \mathrm{~g} /$ cage of the same experimental diet but marked with $5.0 \%$ acid insoluble ash in the form of celite [28]. Marked diets were provided for two hours. At the conclusion of the two-hour period, any remaining feed was removed and weighed to determine feed intake. Unmarked feed that corresponded to diets assigned for each cage was fed upon removal of the marked diet. Water was provided ad libitum throughout the experiment. Fecal collection began four hours after broilers were given marked diets and continued every two hours for the following 14 hours, then again at 24 hours. Excreta samples were 
weighed, freeze dried [23], and ground to $1 \mathrm{~mm}$ [24]. Dry matter and acid insoluble ash were determined according to Vogtmann et al. [29] and feed passage time was calculated.

\section{Statistical Analysis}

In experiment one, a season $\mathrm{x}$ energy $\mathrm{x}$ enzyme factorial split plot design was used in order to explore main effects and interactions of all treatments on performance and carcass characteristics. Pasture access was designated as the main plot. Season, energy, and enzyme constituted the sub plots. A male to female ratio was used as a covariate for performance. All possible linear contrasts were performed in order to explain significant interactions (data not compiled in table). Orthogonal contrasts were used to answer specific interactions between treatments. A second analysis, consisting of a Randomized Complete Block design, was used to analyze forage intake and feed passage time. A male to female ratio and a legume to grass ratio were used as covariates for forage intake. Fisher's Least Significant Difference test was used for multiple comparisons between mean values for forage intake. Duncan's New Multiple Range test was used for multiple comparisons between mean values within each collection time for acid insoluble ash. All statistical analyses were performed using the GLM procedure of the Statistical Analysis System [30]. Alpha was designated as 0.05.

\section{Results and Discussion}

\section{Environmental Conditions}

The environmental conditions during spring and summer months are described in Table 1. Broilers reared in spring months were exposed to lower temperature and humidity, as well as a shorter photoperiod, compared to broilers reared in summer 
months. Precipitation values were similar among study periods. Environmental

conditions are presented as descriptive data to support season effects.

Organic Broiler Performance and Carcass Characteristics

Table 3 contains all performance data for the 21-to-38-day, 38-to-56-day, and 21to-56-day period. Only the 21-to-56-day period will be discussed unless more specific periods are needed to support overall observations. Table 4 describes the carcass characteristics of broilers processed on day 56. In order to negate the effects of varying LWG, gizzard weight $(\mathrm{GRH})$ and fat pad weight $(\mathrm{FRH})$ are presented as a ratio to $\mathrm{HCW}$ and breast weight (BPC) is presented as a percentage of CCW.

Broilers fed LOW diets, despite pair-feeding, ate significantly less than broilers fed NOR diets $(\mathrm{P}=0.0001)$. This result was thought to be due to variation in digestive transit time in the intestine of broilers fed the LOW diet that included washed builder's sand. Feed passage time data (Experiment 2) is described in Table 5. Only broilers fed the LOW/E diet had increased feed passage time $(\mathrm{P}=0.0047$ and $\mathrm{P}=0.0307)$ at six and eight hours post-feeding, respectively. Danicke et al. [31, 32] and Lazaro et al. [33] found that enzyme addition reduced digesta viscosity and increased feed passage time of marker in the digestive tract resulting in an increase in feed intake. In the current study FI was decreased. Therefore, reduction in FI for broilers fed LOW diets is likely due to energy restriction during the growing period. Energy restriction reduces the probability of an animal meeting optimal growth subsequently causing a decrease in FI [34, 35, 36].

An energy $\mathrm{x}$ access interaction was observed for $\mathrm{HCW}(\mathrm{P}=0.0223), \mathrm{CCW}$ $(\mathrm{P}=0.0429)$, and GRH $(\mathrm{P}=0.033)$. Broilers fed LOW diets and given access to pasture had smaller HCW and CCW compared to all other broilers. However, pastured broilers 
fed LOW diets had larger GRH than pastured broilers fed NOR diets or broilers fed either diet and given no access to pasture. An energy $\mathrm{x}$ enzyme $\mathrm{x}$ access interaction was observed for FRH $(\mathrm{P}=0.0455)$. Only when broilers were fed the LOW/NE diet and given access to pasture was FRH significantly reduced. An increase in GRH and a decrease in FRH suggest that broilers fed LOW diets were attempting to compensate for dietary energy restriction through increased foraging activity and a subsequent increase in exercise. This observation is consistent with Moritz et al. [4].

An energy $\mathrm{x}$ enzyme $\mathrm{x}$ access interaction was observed for $\mathrm{LWG}(\mathrm{P}=0.0064)$. Withholding pasture access resulted in increased LWG compared to broilers given pasture access. In addition, consumption of NOR diets improved LWG compared to LOW diets for broilers within pasture access groups. However, enzyme inclusion improved LWG only when broilers were fed NOR diets and given access to pasture. These data suggest that a NSP enzyme may be more beneficial when feeding a balanced ration to broilers given access to pasture.

An enzyme $\mathrm{x}$ season interaction was also observed for $\mathrm{LWG}(\mathrm{P}=0.001)$. Feeding diets with enzyme resulted in increased LWG compared to feeding diets with no enzyme only in spring months. Feed intake $(\mathrm{P}=0.0428)$ was also affected by season. Broilers reared in spring months consumed less feed than broilers reared in summer months. However, broilers reared in spring months had significantly higher FE $(\mathrm{P}=0.0009)$. A shorter photoperiod during the spring months as compared to the summer months (13.58hr vs. $14.92 \mathrm{hr}$ ) may have influenced FI. However, the fact that broilers in spring had larger LWG but consumed less feed suggests that they were able to compensate for decreased feed consumption by more efficiently utilizing feed and forage for growth. 
Broilers reared in spring months had smaller GRH $(\mathrm{P}=0.0001)$ than broilers reared in summer months suggesting that broilers reared in summer months may have consumed a more fibrous forage. Forage intake did not differ among treatments $(\mathrm{P}>0.05)$ or among seasons $(\mathrm{P}>0.05)$ (Table 6). Therefore, these data suggest that forage utilized in summer months had a more fibrous consistency and a decreased nutrient value (Table 1).

The level of NSPs in grains and forages fluctuates depending on season [37, 38]. Nutrient values in grain and forage utilized in this study were superior in spring (Table 1). Nutrient value in forage has been documented to decline as the plant matures. Plant maturation results in an increase in acid detergent fiber and neutral detergent fiber and a decrease in crude protein concentration [5]. Bach-Knudsen reported that the principal polymer of grass meal is cellulose, constituting $48 \%$ of total crude fiber [37]. However, crude fiber composition varies depending on season. First-cut grass has been shown to have a total NSP content of $36.6 \%$ compared to $42.6 \%$ NSP content in second-cut grass [37]. Perhaps enzyme inclusion more easily degraded early-growth forage and grains obtained in the spring leading to more efficient nutrient utilization. Broilers reared in spring months and supplemented with enzyme had a larger CCW and smaller FRH than broilers reared in summer months $(\mathrm{P}=0.0193$ and $\mathrm{P}=0.0235$, respectively). In addition, an enzyme $\mathrm{x}$ season $\mathrm{x}$ access effect was observed for $\mathrm{HCW}(\mathrm{P}=0.0489)$. Pastured broilers fed diets containing enzyme in spring months had larger HCW than pastured broilers fed diets containing no enzyme in spring months or pastured broilers fed either diet in summer months. These data support the theory that the capacity of an NSP enzyme to aid in the degradation of plant cell wall components is accentuated in spring months. 
Mortality was not affected by dietary treatment, enzyme inclusion, pasture access, or season $(\mathrm{P}>0.05)$.

Economic Analysis

In order to determine if there is an economic benefit associated with enzyme incorporation in an organic production system, pastured broilers fed NOR/NE were compared with pastured broilers fed LOW/E. For the overall period, broilers fed NOR/NE had larger LWG $(\mathrm{P}=0.0349$ and $\mathrm{P}=0.0001), \mathrm{HCW}(\mathrm{P}=0.0015$ and $\mathrm{P}=0.0001)$, CCW ( $\mathrm{P}=0.0019$ and $\mathrm{P}=0.0001)$, and improved $\mathrm{FE}(\mathrm{P}=0.0114$ and $\mathrm{P}=0.0064)$ compared to broilers fed LOW/E in spring and summer months, respectively. However, in spring months LWG and FE were not significantly different during the 38-to-56-day period suggesting compensatory growth of broilers fed the LOW/E diet. Forage intake did not differ among treatments. However, forage intake values did increase during the 38-to-56 day period compared to the 21-to-38 day period for all treatments (Table 6). Therefore, it is plausible that broilers given the LOW/E were able to digest more forage in spring months to compensate for decreased growth in the 21-to-38-day period. Broilers fed LOW/E had greater GRH $(\mathrm{P}=0.0001)$ and a lesser FRH $(\mathrm{P}=0.015)$ than broilers fed NOR/NE in summer months. This was not observed in spring months. Broilers fed LOW/E and reared in summer months consumed a more fibrous forage (Table 3 ) that contributed to a larger GRH. Mortality was not affected by dietary treatment or season. Therefore, feeding a LOW/E diet is not a valid means of reducing feed costs and broilers were not able to overcome a 7\% energy restriction through increased foraging activity and enzyme supplementation. 


\section{Conclusions and Applications}

1. Feed restriction did not result in increased forage intake for broilers between treatment or season.

2. In spring months, enzyme inclusion enhanced performance only when broilers were given access to pasture.

3. Reducing dietary energy by $7 \%$ and incorporating an exogenous enzyme is not a viable means for reducing organic feed cost. 


\section{REFERENCES}

1. Dimitri, C. and C. Greene, 2002. Recent growth patterns in the U.S. organic foods market. U.S. Department of Agriculture, Economic Research Service, Market and Trade Economics Division and Resource Economics Division Agriculture Information Bulletin Number 777.

2. Dawkins, M.A., P.A. Cook, M.J. Whittingham, K.A. Mansell, and A.E. Harper, 2003. What makes free-range broiler chickens range? In situ measurement of habitat preference. J. of Anim. Behavior, 66: 151-160.

3. Nielsen, B.L., M.G. Thomsen, P. Sorensen, and J.F. Young, 2003. Feed and strain effects on the use of outdoor areas by broilers. Br. Poult. Sci., 44: 161-169.

4. Moritz, J.S., A.S. Parsons, N.P. Buchanan, N.J. Baker, J. Jaczynski, O.J. Gekara, and W.B. Bryan, 2005. Synthetic methionine and feed restriction effects on performance and meat quality of organically reared broiler chickens. J. Appl. Poult. Res. 14:521-535.

5. Barnes, R.F., D.A. Miller, and C.J. Nelson, 1995. Hay and silage management. Forages: Volume 1 An Introduction to Grassland Agriculture, Published by Iowa State University Press, Ames, IA, pp. 158-159.

6. Kocher, A., M. Choct, M.D. Porter, and J. Broz, 2002. Effects of food enzymes on utilization of lupin carbohydrates by broilers. Br. Poult. Sci., 41: 75-82.

7. Choct, M., R.J. Hughes, J. Wang, M.R. Bedford, A.J. Morgan, and G. Annison, 1996. Increased small intestinal fermentation is partly responsible for the antinutritive activity of non-starch polysaccharides in chickens. Br. Poult. Sci., 37: 609-621.

8. Fengler, A.I. and R. R. Marquardt, 1988. Water-soluble pentosans from 
rye: II. Effects of rate of dialysis and on the retention of nutrients by the chick. Cereal Chem., 65: 298-302.

9. Leeson, S. and J.D. Summers, 2001. Digestion and nutrient availability. Scott's Nutrition of the Chicken, Published by University Books, Guelph, Ontario, p. 5.

10. Francesch, M. and J. Brufau, 2004. Nutritional factors affecting excreta/litter moisture and quality. World's Poult. Sci. J., 60: 64-75.

11. Carre, B., J. Gomez, and A.M. Chagneau, 1995. Contribution of oligosaccharides and polysaccharide digestion, and excreta losses of lactic acid and short chain fatty acids, to dietary metabolizable energy values in broiler chickens and adult cockerels. Br. Poult. Sci., 36: 611-629.

12. Kocher, A, J. Broz, M.D. Porter, and M. Choct, 2002. Effects of feed enzymes on nutritive value of soyabean meal fed to broilers. Br. Poult. Sci. 43:54-63.

13. Edney, M.J., G.L. Campbell, and H.L. Classen, 1989. The effect of ßglucanase supplementation on nutrient digestibility and growth in broilers given diets containing barley, oat groats or wheat. Anim. Feed Sci. Technol. 25:193-200.

14. Pettey, L.A., S.D. Carter, B.W. Senne, and J.A. Shriver, 1999. Effects of Hemicell ${ }^{\circledR}$ addition to nursery diets on growth performance of weanling pigs. Oklahoma State University Animal Science Research Report, 273-279.

15. Pettey, L.A., S.D. Carter, B.W. Senne, and J.A. Shriver, 2000. Effects of Hemicell ${ }^{\circledR}$ addition to corn-soybean meal diets on growth performance, carcass traits, and apparent nutrient digestibility in growing-finishing pigs. Oklahoma State University Animal Science Research Report, 117-122. 
16. Hetland, H. and B. Svihus, 2001. Effect of oat hulls on performance, gut capacity and feed passage time in broiler chickens. Br. Poult. Sci. 42:354-361.

17. Aviagen, Huntsville, AL 35805.

18. National Research Council, 1994. Nutrient Requirements of Poultry. $9^{\text {th }}$ rev. ed. National Academy Press, Washington, DC.

19. Ohio Ecological Food and Farm Association, PO Box 82234 Columbus, $\mathrm{OH}$ 43202.

20. Energy reduction (7\%) was based on an extrapolation of data using metabolizable energy values for alfalfa (NRC) and forage intake data from previous studies at West Virginia University [4]. Average forage intake of restricted-fed birds

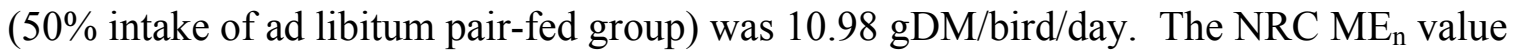
for alfalfa is $1200 \mathrm{kcal} / \mathrm{kg}$ (as fed basis). Assuming a forage intake value of $10.98 \mathrm{gDM} / \mathrm{bird} / \mathrm{day}$ and an estimated $\mathrm{ME}_{\mathrm{n}}$ value of $2000 \mathrm{kcal} / \mathrm{kg}$ (DM basis) for alfalfa, birds with access to pasture may obtain approximately $7 \%$ of their energy requirement from forage.

Forage Inclusion Level Forage Intake of Restrictive-Fed Broilers Average forage intake $(\mathrm{kg} / \mathrm{d}) \times \mathrm{ME}_{\mathrm{n}}$ of alfalfa $(\mathrm{DM}$ basis $)=\mathrm{kcal}$ forage/ day $0.01098 \mathrm{~kg} /$ day $\times 2000 \mathrm{kcal} / \mathrm{kg}=21.96 \mathrm{kcal}$ forage $/$ day

Feed Intake of Restrictive-Fed Broilers Average feed intake $(\mathrm{kg} / \mathrm{d}) \times \mathrm{ME}$ of feed $(\mathrm{DM}$ basis $)=\mathrm{kcal}$ feed $/$ day $0.082 \mathrm{~kg} /$ day $\times 3636.36 \mathrm{kcal} / \mathrm{kg}=298.18 \mathrm{kcal}$ feed $/$ day

Total Intake of Restrictive-Fed Broilers $21.96 \mathrm{kcal}$ forage $/$ day $+298.18 \mathrm{kcal}$ feed $/$ day $=320.14 \mathrm{kcal} \mathrm{feed} /$ day

$$
\begin{aligned}
& \frac{21.96}{320.14}=\frac{x}{100} \\
& x=6.86 \%
\end{aligned}
$$


21. Ronozyme VP (CT). DSM Nutritional Products, CH-4071 Basle, Switzerland.

22. Rayburn, E.B. and S.B. Rayburn, 1998. A standardized plate meter for estimating pasture mass in on-farm research trials. Agron. J. 90:238-241.

23. Vitris Freezemobile 12SL, The Vitris Co., Gardiner, NY 12525.

24. Cyclotec 1093 Sample Mill, Foss Tecator, Eden Prairie, MN 55344.

25. Isoperibol oxygen bomb calorimeter model 1266, Parr Instrument Co., Moline, IL 61265.

26. Kjeltec Auto 1030 Analyzer, Foss Tecator, Eden Prairie, MN 55344.

27. Agricultural Experiment Station, Experiment Station Chemical Laboratories, University of Missouri-Columbia.

28. Celite Corporation, Lompac, CA 93436.

29. Vogtmann, H., P. Frirter, and A.L. Prabuck, 1975. A new method of determining metabolizability of energy and digestibility of fatty acids in broiler diets. $\mathrm{Br}$. Poult. Sci. 16:531-534.

30. SAS Institute, 2000. The SAS System for Windows 2000. Release 8.1. SAS Institute, Inc., Cary, NC.

31. Danicke, S., O. Simon, H. Jeroch, and M. Bedford, 1997a. Interactions between dietary fat type and xylanase supplementation when rye-based diets are fed to broiler chickens. 1. Physico-chemical chime features. Br. Poult. Sci. 38:537-545.

32. Danicke, S., W. Vahjen, O. Simon, and H. Jeroch, 1999. Effects of dietary fat type and xylanase supplementation to rye-based broiler diets on selected bacterial 
groups adhering to the intestinal epithelium, on transit time of feed, and on nutrient digestibility. Poult Sci. 78:1292-1299.

33. Lazaro, R., M. Garcia, P. Medel, and G.G. Mateos, 2003. Influence of enzymes on performance and digestive parameters of broilers fed rye-based diets. Poultry Sci. 82:132-140.

34. Boekholt, H.A., PH Van der Grinten, V.V.A.M. Schreurs, M.J.N. Los, and C.P. Leffering, 1994. Effect of dietary energy restriction on retention of protein, fat, and energy in broiler chickens. Br. Poult. Sci. 35:603-614.

35. Beane, W.L., J.A. Cherry, and W.D. Weaver, Jr., 1979. Intermittent light and restricted feeding of broiler chickens. Poult. Sci. 58:567-571.

36. Mollison, B., W. Guenter, and B.R. Boycott, 1984. Abdominal fat deposition and sudden death syndrome in broilers: the effects of restricted intake, early life caloric (fat) restriction, and calorie: protein ratio. Poult. Sci. 63:1190-1200.

37. Bach-Knudsen, K.E., 1997. Carbohydrate and lignin contents of plant materials used in animal feeding. An. Feed Sci. Tech. 67:319-338.

38. Scott, T.A., F.G. Silversides, H.L. Classen, M.L. Swift, M.R. Bedford, and J.W. Hall, 1998a. Effect of cultivar and environment on the feeding value of western Canadian wheat and barley samples with and without enzyme supplementation. Can. J. Anim. Sci. 78:649-656. 
Table 1. Outside environment conditions.

\begin{tabular}{|c|c|c|c|c|c|c|}
\hline & \multicolumn{3}{|c|}{ Spring Trial } & \multicolumn{3}{|c|}{ Summer Trial } \\
\hline Mean Temp ${ }^{\circ} \mathrm{F}\left({ }^{\circ} \mathrm{C}\right)$ & \multicolumn{3}{|c|}{$57.7(13.9)$} & \multicolumn{3}{|c|}{$70.8(21.1)$} \\
\hline Max Temp ${ }^{\circ} \mathrm{F}\left({ }^{\circ} \mathrm{C}\right)$ & \multicolumn{3}{|c|}{$69.4(20.3)$} & \multicolumn{3}{|c|}{$80.9(26.6)$} \\
\hline Min Temp ${ }^{\circ} \mathrm{F}\left({ }^{\circ} \mathrm{C}\right)$ & \multicolumn{3}{|c|}{$46.1(7.4)$} & \multicolumn{3}{|c|}{$61.3(15.8)$} \\
\hline Precipitation in. $(\mathrm{cm})$ & \multicolumn{3}{|c|}{$0.08(0.19)$} & \multicolumn{3}{|c|}{$0.09(0.23)$} \\
\hline Wind Speed mph $(\mathrm{km} / \mathrm{h})$ & \multicolumn{3}{|c|}{$3.7(6.0)$} & \multicolumn{3}{|c|}{$2.5(3.9)$} \\
\hline Humidity (\%) & \multicolumn{3}{|c|}{67.3} & \multicolumn{3}{|c|}{78.9} \\
\hline \multirow[t]{2}{*}{ Average Length of Day (hr) } & \multicolumn{3}{|c|}{13.58} & \multicolumn{3}{|c|}{14.92} \\
\hline & $\begin{array}{c}\text { Crude Protein } \\
(\%)\end{array}$ & $\begin{array}{c}\mathrm{NDF}^{\mathrm{A}} \\
(\%)\end{array}$ & $\begin{array}{c}\mathrm{ADF}^{\mathrm{B}} \\
(\%)\end{array}$ & $\begin{array}{c}\text { Crude Protein } \\
(\%)\end{array}$ & $\begin{array}{c}\mathrm{NDF}^{\mathrm{A}} \\
(\%)\end{array}$ & $\begin{array}{c}\mathrm{ADF}^{\mathrm{B}} \\
(\%)\end{array}$ \\
\hline Feed Nutrient Content ${ }^{\mathrm{C}}$ & 21.52 & 9.72 & 3.06 & 20.33 & 8.21 & 1.41 \\
\hline Forage Nutrient Content ${ }^{\mathrm{D}}$ & 17.60 & 31.17 & 18.22 & 16.06 & 36.98 & 20.69 \\
\hline
\end{tabular}


Table 2. Diet formulations and nutrient parameters for organic diets.

\begin{tabular}{|c|c|c|c|c|c|}
\hline Ingredients & Starter & Nor/ $E^{A}$ & Nor/ $\mathbf{N E}^{\mathrm{B}}$ & Low $/ \mathbf{E}^{\mathrm{C}}$ & Low/ NE \\
\hline Organic Corn & 51.43 & 58.81 & 58.82 & 50.37 & 50.39 \\
\hline Organic Soybean $\mathrm{FF}^{\mathrm{E}}$ & 41.50 & 31.38 & 31.39 & 33.81 & 33.83 \\
\hline Organic Soybean $\mathrm{FP}^{\mathrm{F}}$ & 2.94 & 6.46 & 6.47 & 5.62 & 5.63 \\
\hline Limestone & 1.45 & 1.53 & 1.55 & 1.34 & 1.36 \\
\hline Dicalcium Phosphate & 1.79 & 1.24 & 1.26 & 1.28 & 1.29 \\
\hline Salt & 0.46 & 0.31 & 0.33 & 0.32 & 0.33 \\
\hline Poultry Premix ${ }^{G}$ & 0.19 & 0.16 & 0.18 & 0.17 & 0.18 \\
\hline DL-Methionine & 0.25 & ----- & ----- & ----- & ------ \\
\hline Sand $^{\mathrm{H}}$ & ------ & ----- & ----- & 6.98 & 6.99 \\
\hline Ronozyme VP & ------ & 0.11 & ------ & 0.11 & ----- \\
\hline \multicolumn{6}{|l|}{ Calculated Nutrients } \\
\hline $\mathrm{ME}(\mathrm{kcal} / \mathrm{kg})$ & 3200 & 3200 & 3200 & 2976 & 2976 \\
\hline Crude Protein (\%) & 22.14 & 19.89 & 19.89 & 19.89 & 19.89 \\
\hline Methionine (\%) & 0.58 & 0.32 & 0.32 & 0.31 & 0.31 \\
\hline \multicolumn{6}{|l|}{ Analyzed Nutrients } \\
\hline Crude Protein (\%) & ----- & 19.75 & 19.03 & 19.54 & 18.82 \\
\hline Methionine & ----- & 0.35 & 0.34 & 0.32 & 0.32 \\
\hline
\end{tabular}

${ }^{\mathrm{A}}$ Normal Energy with Enzyme Inclusion

${ }^{\mathrm{B}}$ Normal Energy with NO Enzyme Inclusion

${ }^{\mathrm{C}}$ Low Energy with Enzyme Inclusion

DLow Energy with NO Enzyme Inclusion

${ }^{E}$ full fat roasted soybeans

${ }^{\mathrm{F}}$ French pressed soybean meal

${ }^{\mathrm{G}}$ Supplied per kg of diet: vitamin $\mathrm{D}_{3}$, $3306 \mathrm{ICU}$; vitamin A, $8816 \mathrm{IU}$; vitamin E, $22 \mathrm{IU}$; vitamin $\mathrm{K}, 1.7 \mathrm{mg}$; thiamin, $1.1 \mathrm{mg}$; riboflavin, 5.5mg; niacin, $44 \mathrm{mg}$; D-pantothenic acid, $11 \mathrm{mg}$; pyridoxine $2.2 \mathrm{mg}$; folic acid $0.6 \mathrm{mg}$; biotin, .03mg; vitamin $\mathrm{B}_{12} ; .013 \mathrm{mg}$; choline $(0.05 \%$ inclusion), $300 \mathrm{mg}$; calcium, $75 \mathrm{mg}$; sodium, $0.02 \mathrm{mg}$; potassium, $1.1 \mathrm{mg}$; magnesium, $21 \mathrm{mg}$; manganese, $144 \mathrm{mg}$; zinc $80 \mathrm{mg}$; iron, $32 \mathrm{mg}$; copper, $8 \mathrm{mg}$; iodine, $1.6 \mathrm{mg}$; selenium, $0.32 \mathrm{mg}$.

${ }^{\mathrm{H}}$ Washed Builders Sand 
Table 3. Influence of enzyme inclusion and dietary energy restriction on 3-to-8-week broiler performance

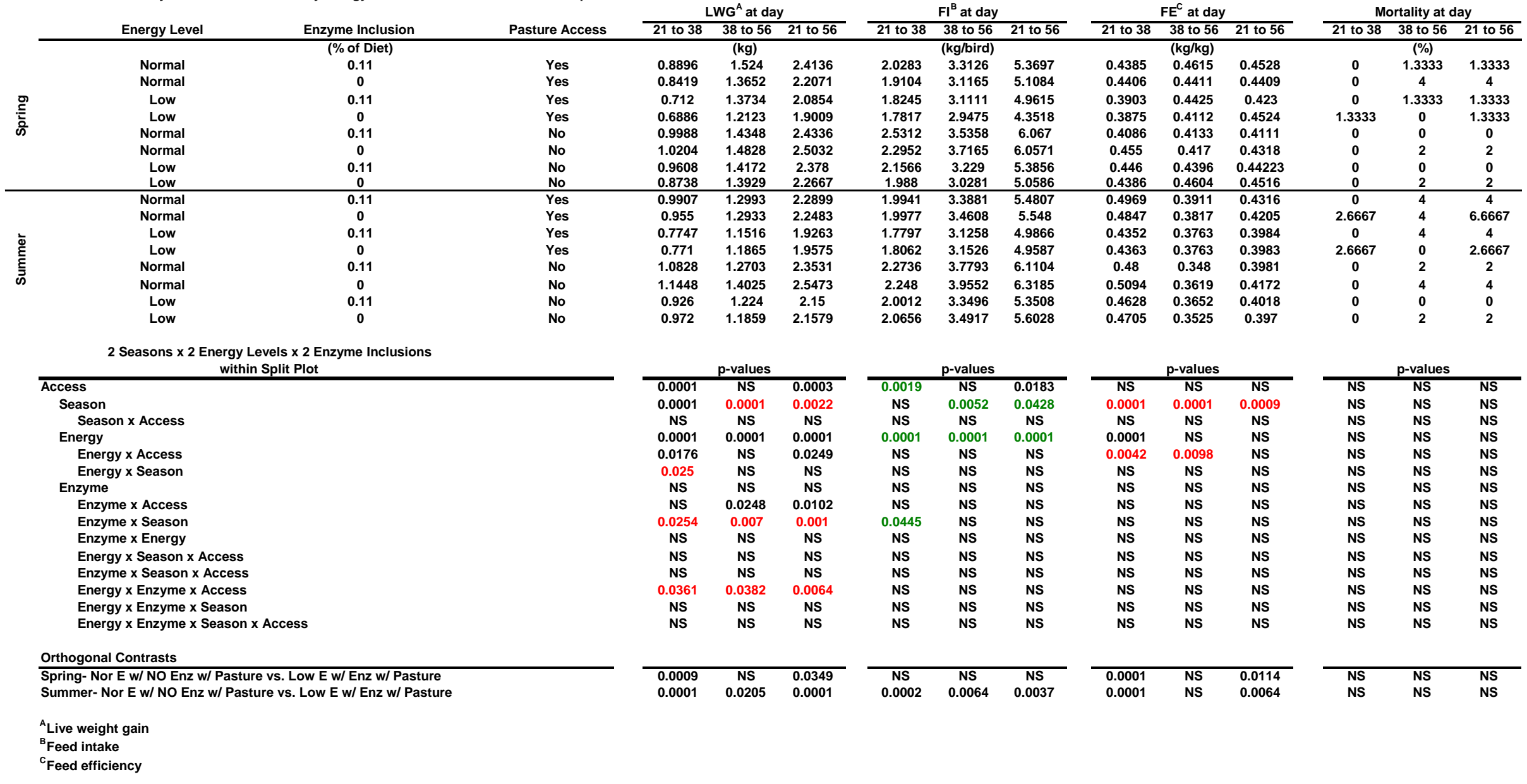


Table 4. Influence of enzyme inclusion and dietary energy restriction on 3-to-8-week broiler carcass characteristics

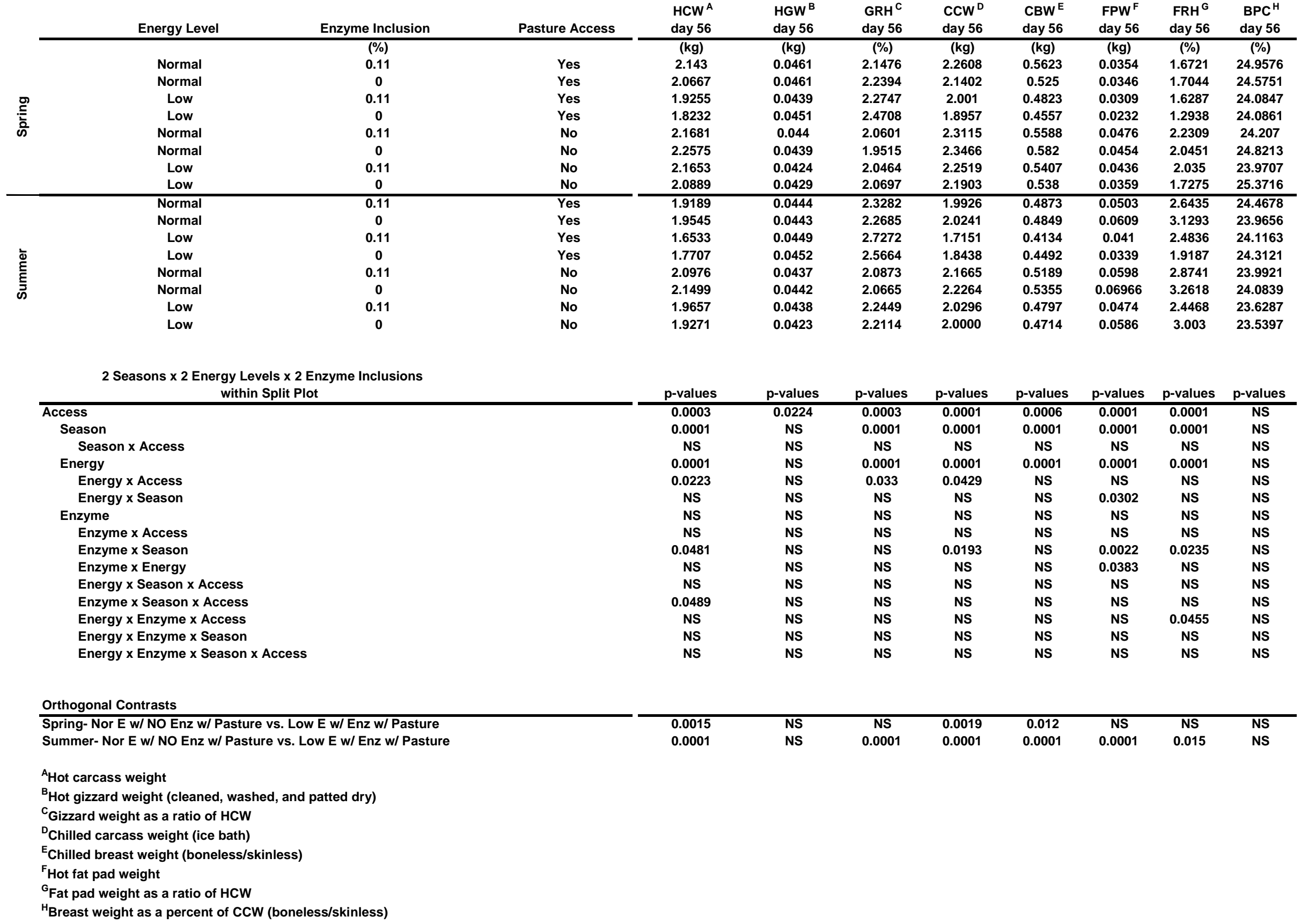


Table 5. Influence of enzyme inclusion and dietary energy restriction on passage time as determined by percent acid insoluble ash.

\begin{tabular}{|c|c|c|c|c|c|c|c|c|c|c|c|}
\hline & & \multicolumn{10}{|c|}{ \% Ash } \\
\hline & & \multicolumn{10}{|c|}{ Time of Collection (hr) } \\
\hline Treatment & $\mathrm{FI}^{\mathrm{A}}(\mathrm{g})$ & $0^{B}$ & 4 & 6 & 8 & 10 & 12 & 14 & 16 & 18 & 24 \\
\hline Nor E w/ Enz & 99.100 & $0.283^{B}$ & 7.512 & $13.398^{\mathrm{B}}$ & $9.372^{\mathrm{B}}$ & 1.353 & 1.081 & 1.402 & 1.236 & 1.140 & 3.564 \\
\hline $\begin{array}{c}\text { Nor E w/ NO } \\
\text { Enz }\end{array}$ & 99.325 & $1.042^{B}$ & 8.800 & $13.095^{\mathrm{B}}$ & $11.444^{\mathrm{B}}$ & 1.617 & 1.157 & 1.148 & 0.698 & 0.737 & 0.191 \\
\hline Low E w/ Enz & 98.100 & $13.715^{\mathrm{A}}$ & 13.553 & $21.231^{\mathrm{A}}$ & $17.282^{\mathrm{A}}$ & 5.268 & 2.165 & 2.343 & 0.983 & 0.618 & 0.000 \\
\hline $\begin{array}{c}\text { Low E w/ NO } \\
\text { Enz }\end{array}$ & 98.550 & $13.174^{\mathrm{A}}$ & 6.969 & $14.819^{B}$ & $11.255^{\mathrm{B}}$ & 2.247 & 1.036 & 1.109 & 1.158 & 1.645 & 0.553 \\
\hline $\begin{array}{l}\text { ANOVA } \\
\text { p-values }\end{array}$ & 0.1665 & 0.0001 & 0.6432 & 0.0047 & 0.0307 & 0.3491 & 0.4771 & 0.8303 & 0.9035 & 0.8789 & 0.4228 \\
\hline
\end{tabular}

Means within a column without a common superscript differ significantly $(\mathbf{P} \leq \mathbf{0 . 0 5})$

$\%$ AIA values for collection times of $4,6,8,10,12,14,16,18$, and 24 post-feeding where corrected for endogenous \%AIA in excreta

${ }^{\text {A }}$ Feed intake per cage

${ }_{\%} \%$ AIA of unmarked feed 
Table 6. Forage intake in treatment paddocks.

\begin{tabular}{|c|c|c|c|c|c|c|c|c|c|c|c|c|c|c|c|c|}
\hline & \multicolumn{8}{|c|}{ Spring Study } & \multicolumn{8}{|c|}{ Summer Study } \\
\hline & \multicolumn{2}{|c|}{$\begin{array}{l}\text { Nor E w/ } \\
\text { Enz }\end{array}$} & \multicolumn{2}{|c|}{$\begin{array}{l}\text { Nor E w/ } \\
\text { NO Enz }\end{array}$} & \multicolumn{2}{|c|}{$\begin{array}{c}\text { Low E w/ } \\
\text { Enz }\end{array}$} & \multicolumn{2}{|c|}{$\begin{array}{l}\text { Low E w/ } \\
\text { NO Enz }\end{array}$} & \multicolumn{2}{|c|}{$\begin{array}{l}\text { Nor E w/ } \\
\text { Enz }\end{array}$} & \multicolumn{2}{|c|}{$\begin{array}{l}\text { Nor E w/ } \\
\text { NO Enz }\end{array}$} & \multicolumn{2}{|c|}{$\begin{array}{c}\text { Low E w/ } \\
\text { Enz }\end{array}$} & \multicolumn{2}{|c|}{$\begin{array}{l}\text { Low E w/ } \\
\text { NO Enz }\end{array}$} \\
\hline $\begin{array}{l}\text { Forage } \\
\text { measurement } \\
\text { period (d-d) }\end{array}$ & $21-38$ & $38-56$ & $21-38$ & $38-56$ & $21-38$ & $38-56$ & $21-38$ & $38-56$ & $21-38$ & $38-56$ & $21-38$ & $38-56$ & $21-38$ & $38-56$ & $21-38$ & $38-56$ \\
\hline $\begin{array}{l}\text { Forage intake } \\
(\mathrm{g} \mathrm{DM} / \mathrm{d})^{\mathrm{A}} \pm \mathrm{SD}\end{array}$ & $\begin{array}{l}110.10 \\
\pm 76.45\end{array}$ & $\begin{array}{l}227.04 \\
\pm 130.28\end{array}$ & $\begin{array}{l}82.20 \\
\pm 62.37\end{array}$ & $\begin{array}{l}315.77 \\
\pm 170.38\end{array}$ & $\begin{array}{l}55.78 \\
\pm 28.24\end{array}$ & $\begin{array}{l}210.08 \\
\pm 102.62\end{array}$ & $\begin{array}{l}135.05 \\
\pm 120.00\end{array}$ & $\begin{array}{l}190.51 \\
\pm 138.80\end{array}$ & $\begin{array}{l}159.38 \\
\pm 85.27\end{array}$ & $\begin{array}{l}228.58 \\
\pm 68.80\end{array}$ & $\begin{array}{l}132.11 \\
\pm 53.66\end{array}$ & $\begin{array}{l}180.35 \\
\pm 34.75\end{array}$ & $\begin{array}{l}159.38 \\
\pm 73.45\end{array}$ & $\begin{array}{l}234.87 \\
\pm 82.81\end{array}$ & $\begin{array}{l}94.37 \\
\pm 46.64\end{array}$ & $\begin{array}{l}222.29 \\
\pm 61.67\end{array}$ \\
\hline
\end{tabular}

Means within a column without a common superscript differ significantly $(\mathbf{P} \leq \mathbf{0 . 0 5})$

${ }^{A}$ forage intake was measured on a dry matter basis per treatment per day [41]. Mean values did not significantly differ between season (P>0.05) or between treatments within season $(\mathbf{P}>\mathbf{0 . 0 5})$. 


\title{
NUTRIENT COMPOSITION AND DIGESTIBILITY OF ORGANIC GROWER DIETS AND PASTURE FORAGES FED TO ROOSTERS
}

\author{
N.P. Buchanan, J.M. Hott, L.B. Merritt, and J.S. Moritz \\ Division of Animal and Veterinary Science \\ West Virginia University, Morgantown, WV 26506 \\ Phone: 304-293-2631 ext. 4446 \\ nbuchana@mix.wvu.edu
}

Keywords: Nutrition, Forage, $\mathrm{AME}_{\mathrm{n}}, \mathrm{TME}_{\mathrm{n}}, \mathrm{TAAD}$

Running Title: DIGESTIBILITY OF FORAGE

Primary Audience: nutritionists, organic/free-range producers, researchers 


\section{Abstract}

Fifty years ago poultry were commonly reared on pasture. Today poultry diets are formulated based on requirements of birds reared in confinement. Consumer demand for organic and free-range poultry has resulted in an increase in use of certified organic rations and pasture by poultry producers. In conjunction with feed, poultry may have the ability to utilize nutrients found in forage. The objectives of this study were three-fold; 1) to assess changes in $\mathrm{AME}_{\mathrm{n}}$ and $\mathrm{TME}_{\mathrm{n}}$ of organic grower diets with or without enzyme supplementation compared to a conventional grower diet, 2) to assess changes in $\mathrm{AME}_{\mathrm{n}}$, $\mathrm{TME}_{\mathrm{n}}$, and TAAD of forage samples with or with enzyme supplementation and 3) to determine if modification of the cecum affects forage $\mathrm{AME}_{\mathrm{n}}, \mathrm{TME}_{\mathrm{n}}$, and TAAD for cecectomized roosters, intact roosters, and intact roosters fed grass. The experiment was conducted using 98 Single Comb White Leghorn W-36 roosters. Roosters were divided into three groups designated as cecectomized (CEC), intact (CONV), and intact fed grass $(\mathrm{C}+\mathrm{G})$. Dietary treatments consisted of four organic grower diets formulated using an energy level (NOR vs. LOW) x NSP enzyme inclusion factorial (E or NE), a conventional grower diet (GROW), a composite forage sample (FOR/NE), and a composite forage sample supplemented with an exogenous NSP enzyme (FOR/E). Four roosters from each bird type were utilized to obtain endogenous losses. Dietary treatment significantly affected $\mathrm{AME}_{\mathrm{n}}$ and $\mathrm{TME}_{\mathrm{n}}(\mathrm{P}=0.0001$ and 0.0001 , respectively). Enzyme supplementation of organic feeds significantly increased $A M E_{n}$ and $T M E_{n}$ values $\left(\mathrm{P}=0.0213\right.$ and $\mathrm{P}=0.0234$, respectively). Bird type had no effect on $\mathrm{AME}_{\mathrm{n}}$ and $\mathrm{TME}_{\mathrm{n}}$ for any treatment $(\mathrm{P}=0.2453$ and $\mathrm{P}=0.3609)$. True amino acid digestibility of forage was not affected by enzyme supplementation $(\mathrm{P}>0.05)$. However, trends in bird type were 
observed for several amino acids $(\mathrm{P}<0.11)$. Manipulation of cecal microbial population had no effect on $\mathrm{AME}_{\mathrm{n}}, \mathrm{TME}_{\mathrm{n}}$, or TAAD $(\mathrm{P}>0.05)$.

\section{Description of Problem}

Fifty years ago the majority of poultry were reared in small-farm flocks utilizing pasture as a primary nutrient source. Good pasture provided the bulk of vitamins and also supplied a preponderance of protein and minerals [1]. Today, nutritionists formulate diets based on recommendations by the National Research Council (NRC) [2]. However, recommendations focus on poultry reared in confinement.

Given the recent consumer demand for increased animal welfare and concern over the composition of broiler diets, organic poultry production has become a growing segment of the poultry industry. Organic poultry have access to pasture; a nutrient source that has not been fully evaluated for use in poultry. Laying hens and broiler chickens given access to pasture may meet various nutrient needs through foraging.

Buckner et al. found that giving laying hens access to early-growth Kentucky Bluegrass resulted in a $20 \%$ reduction in feed consumption and increased egg production compared to hens raised in confinement $[3,4]$. Additionally, hens reared on alfalfa or ladino clover need considerably less feed protein than confined hens [1]. High quality alfalfa hay can supply carotene and help furnish Vitamin K and E [1]. Feed having only 11 to 12 percent protein has been shown to be adequate for hens on good pasture [5]. Additionally, Moritz et al. reported that commercial broilers may overcome growth impairments associated with methionine deficiency through foraging [6].

Plant cell walls are typically composed of cellulose, non-starch polysaccharides (NSP), pectin, and lignin [7]. The NSP portion of the plant is associated with anti- 
nutritive factors that may lead to poor digestibility in the chicken $[8,9]$. Researchers have partially combated problems with NSP anti-nutritive factors by supplementing feedstuffs with exogenous enzymes $[10,11,12]$.

Bird type and diet composition may influence metabolizable energy and amino acid digestibility values. Sibbald and Slinger [13] and Slinger et al. [14] reported that the use of leghorns as an assay for ME may result in an overestimation of energy available to broiler-type chickens. In contrast, Potter has reported that varying breeds may be used if digestibility values are corrected to zero nitrogen retention to account for variation in protein accretion and protein catabolism [15]. High fiber diets have resulted in increased $\mathrm{N}$ excretion and large variability in $\mathrm{TME}_{\mathrm{n}}$ values $[16,17,18]$ and may subsequently affect amino acid digestibility [17].

The ceca comprise a major part of the large intestine in poultry and provide a habitat for numerous microorganisms [19]. Changes in diet composition may alter the microbial population of the ceca [20]. Duke et al. has theorized that lack of digestibility variation in low and high fiber diets is due to the absence of an adaptation period and that providing a high fiber diet prior to experimentation may stimulate development of cecal flora more capable of fiber digestion [21]. However, the nutritional advantage of hindgut fermentation to the bird is unclear. Past research has shown that amino acids are not absorbed in the hindgut of the chicken in nutritionally significant quantities [22]. Johnson [23] and Ragland et al. [24] have stated that cecectomized birds should be used to prevent overestimation of amino acid digestibility in feedstuffs. Parsons [25] and Son [26] reported greater excretion of amino acids and improved nitrogen utilization in cecectomized birds compared to intact birds due to the lack of microbial fermentation. 
The objectives of this study were 1) to assess changes in $\mathrm{AME}_{\mathrm{n}}$ and $\mathrm{TME}_{\mathrm{n}}$ of organic grower diets with or without enzyme supplementation compared to a conventional grower diet, 2) to assess changes in $\mathrm{AME}_{\mathrm{n}}, \mathrm{TME}_{\mathrm{n}}$, and TAAD of forage samples with or with enzyme supplementation and 3) to determine if addition of forage to the diet affects forage $\mathrm{AME}_{\mathrm{n}}, \mathrm{TME}_{\mathrm{n}}$, and TAAD for cecectomized roosters, intact roosters, and intact roosters fed grass.

\section{Materials and Methods}

Ninety-six male Single Comb White Leghorn Hy-line W-36 roosters were obtained from a commercial pullet house at 13 weeks of age [27]. Birds were transported to the West Virginia University poultry farm and housed in floor pens located in a crossventilated negative pressure room. Water was provided ad libitum through nipple drinkers and a rooster maintenance diet $(12 \% \mathrm{CP}, 3200 \mathrm{kcal} / \mathrm{kg} \mathrm{ME})$ was provided for ad libitum consumption. Temperature was maintained at $70^{\circ} \mathrm{C}$ to provide maximum bird comfort. A 21-day adaptation period was utilized to ensure that roosters were acclimated to new facilities.

At the conclusion of the adaptation period, roosters were withheld feed for 24 hours. Thirty-two roosters were chosen at random and cecectomy surgeries were performed [28]. These birds were designated as cecectomized roosters (CEC) and fed the maintenance diet following recovery. The remaining 64 roosters were divided into two groups. One group was fed only the maintenance diet (CONV). The second group was fed the same maintenance diet supplemented with grass clippings mixed at a $7 \%$ inclusion level as determined by past research $(C+G)[29]$. This diet was fed for 4 weeks 
and utilized to establish a microbial population in the ceca that may be similar to a broiler chicken with access to pasture.

Following a 4-week recovery/diet adaptation period, all roosters were moved to a cross-ventilated negative pressure room and individually housed in $18 \mathrm{in} \mathrm{x} 18 \mathrm{in}(45.72 \mathrm{~cm}$ $\mathrm{x} 45.72 \mathrm{~cm}$ ) raised wire cages containing cup drinkers and external feed troughs. Roosters were randomly assigned to one of seven dietary treatments. Four treatments consisted of diets utilized in a preceding organic broiler performance study [30]. These diets were normal energy with no enzyme (NOR/NE), normal energy with enzyme (NOR/E), low energy with no enzyme (LOW/NE), and low energy with enzyme (LOW/E). Diets were certified organic. The low energy diet was utilized to test enzyme efficacy in the preceding organic broiler performance study. The NSP enzyme was derived from the fermentation of Aspergillus aculeatus and contained $\beta$-glucanase, pentosanase, and hemicellulase hydrolysis activities and was included in the diet at $0.11 \%$ when applicable [31]. A conventional broiler grower diet (GROW) was utilized to compare organic grower diets to conventional grower diets (Table 2). The two remaining treatments consisted of a composite forage sample (FOR/NE) and a composite forage sample mixed with the same NSP enzyme (FOR/E) [32]. The composite forage samples were harvested from the poultry pasture paddocks at the West Virginia University Organic Farm. A typical poultry pasture paddock at the WVU Organic Farm contains Kentucky Bluegrass, tall fescue, white clover, and red clover. Three bird types were utilized $(\mathrm{CEC}, \mathrm{CONV}, \mathrm{C}+\mathrm{G})$ and all dietary treatments were replicated four times within each bird type. Four roosters from each bird type were used to estimate endogenous losses. 
Digestibility assays were performed using the procedure outline by McNab [33]. A 48-hour fasting period was utilized in order to clear any undigested material from the GI tract. At the conclusion of the fasting period, roosters were precision-fed $30 \mathrm{~g}$ of feed or $17 \mathrm{~g}$ of forage via a tube inserted directly into the crop. Water was provided ad libitum through nipple drinkers. Excreta were collected for 48 hours by placing individual plastic trays under wire cages. Excreta samples were weighed, dried [34], and ground to $1 \mathrm{~mm}$ [35]. All dried ground excreta were analyzed for gross energy [36] and nitrogen [37]. Additionally, excreta from roosters precision-fed the FOR/NE and FOR/E were analyzed for amino acid content [38]. Values for $\mathrm{TME}_{\mathrm{n}}$ and $\mathrm{AME}_{\mathrm{n}}$ were calculated for all roosters and true amino acid digestibility (TAAD) was calculated for roosters precision-fed FOR/NE and FOR/E. All leghorn roosters were utilized in accordance to protocols established by the West Virginia University Animal Care and Use Committee- ACUC \# 04-0201 (Appendix V).

\section{Statistical Analysis}

The GLM analysis of variance procedure of the Statistical Analysis System (SAS) [39] was used to compare $\mathrm{AME}_{\mathrm{n}}$ and $\mathrm{TME}_{\mathrm{n}}$ for all treatments and TAAD for forage. Fisher's Least Significant Difference test was used for multiple comparisons between mean values of all treatments for $\mathrm{AME}_{\mathrm{n}}$ and $\mathrm{TME}_{\mathrm{n}}$ and for mean values of forage treatments for TAAD. A bird type $\mathrm{x}$ diet factorial randomized complete block analysis was utilized in order to explore main effects and interactions for $\mathrm{AME}_{\mathrm{n}}$ and $\mathrm{TME}_{\mathrm{n}}$ for all dietary treatments and TAAD for forage. Roosters were blocked by location within the room. Orthogonal contrasts were utilized to assess effects of overall enzyme 
supplementation, enzyme supplementation in organic diets, and enzyme supplementation in forage for $\mathrm{AME}_{\mathrm{n}}$ and $\mathrm{TME}_{\mathrm{n}}$. Alpha was designated as 0.05 .

\section{Results and Discussion}

$\underline{\mathrm{AME}_{\mathrm{n}}} \underline{\text { and }} \mathrm{TME}_{\underline{\underline{n}}}$

Values for $\mathrm{AME}_{\mathrm{n}}$ and $\mathrm{TME}_{\mathrm{n}}$ are represented in Table 3. Variation was observed between $\mathrm{AME}_{\mathrm{n}}$ and $\mathrm{TME}_{\mathrm{n}}$ values within dietary treatment (Table 3). Formulated metabolizable energy is consistent with $\mathrm{AME}_{\mathrm{n}}$ values for organic and conventional grower diets (Table 1 and 2). Nitrogen-corrected TME values for feed were approximately $573.7 \mathrm{kcal} / \mathrm{kg}$ higher than $\mathrm{AME}_{\mathrm{n}}$ values. This trend was also reported by Francesch [40] and Yaghobfar and Boldaji [41].

Dietary treatment significantly affected both $\mathrm{AME}_{\mathrm{n}}$ and $\mathrm{TME}_{\mathrm{n}}$ values $(\mathrm{P}=0.0001$ and $\mathrm{P}=0.0001$, respectively) (Table 3). Roosters precision-fed NOR/E, NOR/NE, and GROW did not differ significantly ( $\mathrm{P}=0.0001)$. However, roosters precision-fed the LOW/E had similar $\mathrm{AME}_{\mathrm{n}}$ and $\mathrm{TME}_{\mathrm{n}}$ values compared to roosters precision-fed $\mathrm{NOR} / \mathrm{NE}$ and higher $\mathrm{AME}_{\mathrm{n}}$ and $\mathrm{TME}_{\mathrm{n}}$ values compared to roosters precision-fed LOW/NE $(\mathrm{P}=0.0001)$. The variation in enzyme effect between normal energy diets and low energy diets is supported by Kocher [42] and Scott [43]. Kocher reported no significant enzyme effect in AME when broiler chickens were fed a nutritionally adequate lupin-based diet [42]. However, Scott et al. reported an enzyme effect only when broiler chicks were restricted to $80 \%$ and $60 \%$ intake. Restricted fed birds had similar AME values compared to ad libitum fed birds when supplemented with a NSP enzyme; however, restricted-fed birds were not able to overcome nutrient deficiencies when diets were not supplemented with a NSP enzyme [43]. The authors contribute this 
finding to an increase in a restricted-fed bird's ability to digest the feedstuff and attain higher growth. Forage $\mathrm{AME}_{\mathrm{n}}$ and $\mathrm{TME}_{\mathrm{n}}$ values were lower than all other dietary treatments $(\mathrm{P}=0.0001)$ (Table 3). Villamide and San Juan reported similar findings with high fiber diets [44]. These data suggest that poultry may obtain a small amount of energy from forage. This communication's companion paper reported that broiler chickens were not able to overcome a $7 \%$ reduction in dietary energy through forage alone [30]. However, forage energy content in the aforementioned paper was overestimated. Metabolizable energy values for alfalfa were used to estimate energy content of the forage. Alfalfa values (1200 kcal $/ \mathrm{kg}$ as fed) were higher than the $\mathrm{AME}_{\mathrm{n}}$ and $\mathrm{TME}_{\mathrm{n}}$ values reported in Table 3.

Orthogonal contrasts resulted in enzyme supplementation significantly affecting $\mathrm{AME}_{\mathrm{n}}$ and $\mathrm{TME}_{\mathrm{n}}$ values of organic grower diets $(\mathrm{P}=0.0213$ and $\mathrm{P}=0.0234$, respectively). Roosters precision-fed organic diets supplemented with an exogenous enzyme had higher $\mathrm{AME}_{\mathrm{n}}$ and $\mathrm{TME}_{\mathrm{n}}$ values than roosters precision-fed organic diets with no enzyme supplementation. These data are consistent with Brenes et al. and Chidothe [10,11]. Supplementing forage with enzyme did not significantly affect $\mathrm{AME}_{\mathrm{n}}$ or $\mathrm{TME}_{\mathrm{n}}$; however, there was a trend toward a numerical increase in $\mathrm{AME}_{\mathrm{n}}$ and $\mathrm{TME}_{\mathrm{n}}$ values for roosters precision-fed FOR/E ( $\mathrm{P}=0.1906$ and 0.1903 , respectively). Additionally, bird type had no effect on $\mathrm{AME}_{\mathrm{n}}$ or $\mathrm{TME}_{\mathrm{n}}$ values for all dietary treatments $(\mathrm{P}=0.2453$ and $\mathrm{P}=0.3609$, respectively). 


\section{TAAD for Forage}

The nutrient composition of the forage treatment is represented in Table 4 . Values for TAAD are represented in Table 5. TAAD values for forage samples were similar to TAAD values for alfalfa meal reported by the NRC [2] and Han and Parsons [45]. Roosters precision-fed the FOR/E treatment had numerically higher TAAD than roosters fed the FOR/NE treatment with the exception of arginine, methionine, and tyrosine (Table 5). However, enzyme supplementation did not significantly affect TAAD for any amino acid $(\mathrm{P}>0.05)$.

Bird type resulted in TAAD trends for aspartic acid $(\mathrm{P}=0.0893)$, serine ( $\mathrm{P}=0.1025)$, glutamic acid $(\mathrm{P}=0.0714)$, alanine $(\mathrm{P}=0.0919)$, leucine $(\mathrm{P}=0.0864)$, phenylalanine ( $\mathrm{P}=0.1013)$, and tyrosine $(\mathrm{P}=0.0849)$ (Table 5). Cecectomized roosters excreted more of the respective amino acid than $\mathrm{CONV}$ and $\mathrm{C}+\mathrm{G}$ roosters resulting in a lower digestibility (data not compiled in table). Han and Parsons reported a significant decrease in digestibility between cecectomized and intact roosters for all aforementioned amino acids with the exception of leucine [45]. Parsons has stated that TAAD values obtained from cecectomized roosters more accurately describe amino acid digestibility of the bird than TAAD values obtained from intact roosters [46]. These data suggest that poultry may utilize a significant amount of amino acids found in forage to meet nutrient needs. However, early inclusion of grass into the diet was not found to affect amino acid digestibility of forage. 


\section{Conclusions and Applications}

1. Supplementing organic grower diets with an exogenous NSP enzyme cocktail may increase rooster $\mathrm{AME}_{\mathrm{n}}$ and $\mathrm{TME}_{\mathrm{n}}$.

2. Poultry may obtain small amounts of energy from pasture forage (285.4 to 541.8 $\mathrm{kcal} / \mathrm{kg})$.

3. Poultry have the ability of utilize amino acids found in forage to meet their nutrient requirements. True amino acid digestibility values for methionine, threonine, and lysine were approximately $88 \%, 84 \%$, and $79 \%$, respectively.

4. Manipulation of the diet to alter cecal microbial population has no effect on $\mathrm{TME}_{\mathrm{n}}$, $\mathrm{AME}_{\mathrm{n}}$, and TAAD for roosters fed forage. 


\section{REFERNCES}

1. Anonymous, 1956. General problems in poultry production. Page 928-967 in Feeds and Feeding. F.B. Morrison, ed. Ithaca, New York.

2. National Research Council, 1994. Nutrient Requirements of Poultry. $9^{\text {th }}$ rev. ed. National Academy Press, Washington, DC.

3. Buckner, G.D., W.M. Insko, Jr., and A. Harms, 1943. Spring bluegrass versus mature bluegrass as pasture for laying hens. Poult. Sci., 22:248-251.

4. Buckner, G.D., W.M. Insko, Jr., and A.H. Henry, 1945. Influences of spring bluegrass and mature bluegrass pastures on laying hens and on the eggs produced. Poult. Sci., 24:446-450.

5. Duckworth, 1954. Scotland, Proc. Nutr. Soc. of Great Britain, 13:33.

6. Moritz, J.S., A.S. Parsons, N.P. Buchanan, N.J. Baker, J. Jaczynski, O.J. Gekara, and W.B. Bryan, 2005. Synthetic Methionine and feed restriction effects on performance and meat quality of organically reared broiler chickens. JAPR., 14:521-535.

7. Alberts, B., A. Johnson, J. Lewis, M. Raff, K. Roberts, and P. Walter, 2002. Cells in Their Social Context. Molecular Biology of the Cell, Published by Garland Science, New York, NY, p. 1118-1124.

8. Choct, M., R.J. Hughes, J. Wang, M.R. Bedford, A.J. Morgan, and G. Annison, 1996. Increased small intestinal fermentation is partly responsible for the antinutritive activity of non-starch polysaccharides in chickens. Br. Poult. Sci., 37: 609-621.

9. Leeson, S. and J.D. Summers, 2001. Digestion and nutrient availability. Scott's Nutrition of the Chicken, Published by University Books, Guelph, Ontario, p. 5. 
10. Brenes, A., B.A. Slominski, R.R. Marquardt, W. Guenter, and A. Viveros, 2003. Effect of enzyme addition on the digestibilities of cell wall polysaccharides and oligosaccharides from whole, dehulled, and ethanol-extracted white lupins in chickens. Poult. Sci., 82: 1716-1725.

11. Chidothe, T., R.M. McDevitt, and T. Acamovic, 2002. The effect of enzyme supplementation on the nutritional value of brewers and distillers grains for broiler chickens. Brit. Poult. Sci., 43 (5/Suppl): s30-s31.

12. Wang, Z.R., S.Y. Qiao, W.Q. Lu, and D.F. Li, 2005. Effects of enzyme supplementation on performance, nutrient digestibility, gastrointestinal morphology, and volatile fatty acid profiles in the hindgut of broilers fed wheat-based diets. Poult. Sci., $84: 875-881$

13. Sibbald, I.R., and S.J. Slinger, 1963a. The effects of breed, sex, and arsenical and nutrient density on the utilization of dietary energy. Poult. Sci., 42: 1325-1332.

14. Slinger, S.J., I.R. Sibbald, and W.F. Pepper, 1964. The relative abilities of two breeds of chickens and two varieties of turkeys to metabolizable dietary energy and dietary nitrogen. Poult. Sci., 43: 329-333.

15. Potter, L.M., 1972. The precision of measuring metabolizable energy in poultry feedstuffs. Feedstuffs, 44:28.

16. Beames, R.M. and B.O. Eggum, 1981. The effect of type and level of protein, fibre, and starch on nitrogen excretion patterns in rats. Brit. J. Nutr., 46:301-313.

17. Parsons, C.M., L.M. Potter, and R.D. Brown, Jr., 1983. Effects of dietary carbohydrate and of intestinal microflora on excretion of endogenous amino acids by poultry. Poult. Sci., 62: 483-489. 
18. Sibbald, I.R., 1979. The effect of duration of the excreta collection period on the true metabolizable energy values of feedingstuffs with slow rate of passage. Poult. Sci., 58: 896-899.

19. Barnes, E.M., G.C. Mead, D.A. Barnum, and E.G. Harry, 1972. The intestinal flora of the chicken in the period of 2 to 6 weeks of age, with particular reference to the anaerobic bacteria. Brit. Poult. Sci., 13: 311-326.

20. Farell, D.J., and K.A. Johnson, 1972. Utilization of cellulose by pigs and its effect on cecal function. J. Anim. Sci., 65: 488-496.

21. Duke, G.E., E. Eccleston, S. Kirkwood, C.F. Louis, and H.P. Bedbury, 1984. Cellulose digestion by domestic turkeys fed low or high fiber diets. J. Nutr., 114: 95-102.

22. Webb, K.E., 1990. Intestinal absorption of protein hydrolysis products: a review. J. An. Sci., 6: 3011-3022.

23. Johnson, R.J., 1992. Principles, problems, and application of amino acid digestibility in poultry. World's Poult. Sci., 48: 232-246.

24. Ragland, D., C.R. Thomas, R.G. Elkin, D.J. Shafer, and O. Adeola., 1999. The influence of cecectomy on metabolizable energy and amino acid digestibility of select feedstuffs for white pekin ducks. Poult. Sci., 78: 707-713.

25. Parsons, C.M., 1984. Influence of cecectomy and source of dietary fiber or starch on excretion of endogenous amino acids by laying hens. Brit. J. Nutr. 51: 541-548.

26. Son, J.H., Y. Karasawa, and K.H. Nahm, 2000. Effect of cecectomy on growth, moisture in excreta, gastrointestinal passage time, and uric acid excretion in growing chicks. Brit. Poult. Sci., 41:72-74.

27. Wenger Feed Mills, Inc., Rheems, PA 17570. 
28. University of Illinois Cecetomy Surgery Protocol. A small area along the wing vein was plucked and alcohol was applied to the site. Sodium pentabarbitol (65 $\mathrm{mg} / \mathrm{ml}$ ) was injected into the wing vein, at a dosage of $20-30 \mathrm{mg} / \mathrm{kg}$, using a $3 \mathrm{ml}$ syringe and a 26-gauge needle. After properly anesthetizing the bird, the right leg was suspended over the ribcage and the feathers along the surgical site were removed. Betadine was evenly applied throughout the entire surgical site to reduce chances of infection. The analgesic lidocaine was injected in a $1 \mathrm{ml}$ dose into the muscle surrounding the surgical site using a syringe and a 25-gauge, 5/8-inch needle. A 1.5-inch horizontal incision was made along the lower left abdomen using a 10 blade. Tweezers and iris surgical scissors were used to cut and separate muscle layers until the peritoneal cavity was exposed. The intestine and attached ceca were pulled through the incision using Allis tissue forceps. After the ceca were located, the tissue was ligated using hemostats. 2-0 silk sutures were placed along the intestinal wall and the ceca were removed. The entire abdominal cavity was saturated with penicillin to prevent infection and the muscle layer and dermal layer were sutured using 3-0 chromic gut suture and a 3/8 reverse cutting needle. Throughout the duration of the procedure, reflexes were monitored by pinching the comb of bird. Following the conclusion of the surgery, the birds were returned to raised wire cages and provided ad libitum feed and water. Iodine was administered along the surgical site. Oxytetracycline was injected intramuscularly directed following surgery.

29. Grass inclusion was based on an extrapolation of data using forage intake values from as-yet unpublished data at West Virginia University. Forage was included in the diet as percent of total intake.

Average Forage Intake $(\mathrm{gDM} / \mathrm{b} / \mathrm{d})=11.943936$

Average Feed Intake $(\mathrm{g} / \mathrm{b} / \mathrm{d})=153.61999 \mathrm{~g} / \mathrm{b} / \mathrm{d}$ 
Total Intake=11.943936 gDM/b/d $+153.61999 \mathrm{~g} / \mathrm{b} / \mathrm{d}=165.556392 \mathrm{~g} / \mathrm{b} / \mathrm{d}$

$\%$ grass $=$ Amount of grass $(\mathrm{gDM} / \mathrm{b} / \mathrm{d}) /$ Total Intake $(\mathrm{g} / \mathrm{b} / \mathrm{d})$

$\%$ grass $=11.943936 \mathrm{gDM} / \mathrm{b} / \mathrm{d} \div 165.556392 \mathrm{~g} / \mathrm{b} / \mathrm{d} \times 100=7.21442 \%$

30. Buchanan, N.P., L.B. Merritt, A.S. Parsons, G.E. Seidel, W.B. Bryan, and J.S. Moritz, 2005. The effects of non-starch polysaccharide enzyme addition and dietary energy restriction on performance and carcass quality of organic broiler chickens. (unpublished)

31. Ronozyme VP (CT). DSM Nutritional Products, CH-4071 Basle, Switzerland.

32. Enzyme inclusion was based on data from an as-yet unpublished study at West Virginia University. The enzyme was force-fed to the bird based on daily forage intake values and the correlation to feed intake.

Average Forage Intake $(\mathrm{gDM} / \mathrm{b} / \mathrm{d})=10.99930632$

Average Feed Intake $(\mathrm{g} / \mathrm{b} / \mathrm{d})=148.5607143$

Inclusion Level of Enzyme $=1000 \mathrm{~g}$ enz $/ \mathrm{ton}=0.001102 \mathrm{~g}$ enz $/ \mathrm{g}$ feed

$0.001102 \mathrm{~g} \mathrm{enz} / \mathrm{g}$ feed $\mathrm{x} 148.5607143 \mathrm{~g}$ feed $=0.163713907 \mathrm{~g} \mathrm{enz} / \mathrm{b} / \mathrm{d}$ $\underline{10.99930632 \mathrm{~g} \text { forage }}=\underline{17 \mathrm{~g} \text { forage }}$

$0.163713907 \mathrm{~g}$ enz. $\quad \mathrm{X}$

$10.99930632 x=2.783136419$

$\mathrm{x}=0.253028358 \mathrm{~g}$ forage included in forage + enzyme

33. McNab, J.M. and J.C. Blair, 1988. Modified assay for true and apparent metabolisable energy based on tube feeding. Br. Poult. Sci. 29:697-707.

34. Vitris Freezemobile 12SL, The Vitris Co., Gardiner, NY 12525.

35. Cyclotec 1093 Sample Mill, Foss Tecator, Eden Prairie, MN 55344.

36. Isoperibol oxygen bomb calorimeter model 1266, Parr Instrument Co., Moline, IL 61265. 
37. Kjeltec Auto 1030 Analyzer, Foss Tecator, Eden Prairie, MN 55344.

38. Agricultural Experiment Station, Experiment Station Chemical Laboratories, University of Missouri-Columbia.

39. SAS Institute, 2000. The SAS System for Windows 2000. Release 8.1. SAS Institute, Inc., Cary, NC.

40. Francesch, M., K. Bernard, and J.M. McNab, 2002. Comparison of two direct bioassays using 3-week-old broilers to measure the metabolizable energy of diets containing cereals high in fiber: differences between true and apparent metabolizable energy values. Brit. Poult. Sci., 44: 580-587.

41. Yaghobfar, A., and F. Boldaji, 2002. Influence of level of feed input and procedure on metabolizable energy and endogenous energy loss (EEL) with adult cockerels. Brit. Poult. Sci., 43: 696-704.

42. Kocher, A., M. Choct, R.J. Hughes, and J. Broz, 2000. Effect of food enzymes on utilization of lupin carbohydrates by broilers. Brit. Poult. Sci., 41: 75-82.

43. Scott, T.A., M.A. Leslie, and A. Karimi, 2001. Measurements of enzyme response with hulless barley-based diets full-fed to Leghorn and broiler chicks or restricted-fed broiler chicks. Can. J. Anim. Sci., 81: 403-410.

44. Villamide, M.J., and L.D. San Juan, 1998. Effect of chemical composition of sunflower seed meal on its true metabolizable energy and amino acid digestibility. Poult. Sci., 77: 1884-1892. 
45. Han, Y., and C.M. Parsons, 1990. Determination of available amino acids and energy in alfalfa meal, feather meal, and poultry by-product meal by various methods. Poult. Sci., 69: 1544-1552.

46. Parsons, C.M., 1986. Determination of digestible and available amino acids in meat meal using conventional and cecectomized cockerels or chick growth assays. Br. J. Nutr., 56: 227-240. 
Table 1. Diet formulations and nutrient parameters for organic diets.

\begin{tabular}{|c|c|c|c|c|}
\hline Ingredients & Nor/ $\mathbf{E}^{\mathrm{A}}$ & Nor/ NE ${ }^{B}$ & Low/ E & Low/ NE ${ }^{\mathrm{D}}$ \\
\hline Organic Corn & 58.81 & 58.82 & 50.37 & 50.39 \\
\hline Organic Soybean $\mathrm{FF}^{\mathrm{E}}$ & 31.38 & 31.39 & 33.81 & 33.83 \\
\hline Organic Soybean $\mathrm{FP}^{\mathrm{F}}$ & 6.46 & 6.47 & 5.62 & 5.63 \\
\hline Limestone & 1.53 & 1.55 & 1.34 & 1.36 \\
\hline Dicalcium Phosphate & 1.24 & 1.26 & 1.28 & 1.29 \\
\hline Salt & 0.31 & 0.33 & 0.32 & 0.33 \\
\hline Poultry Premix ${ }^{\mathrm{G}}$ & 0.16 & 0.18 & 0.17 & 0.18 \\
\hline DL-Methionine & ------ & ------ & ------ & ------ \\
\hline Sand $^{\mathrm{H}}$ & ------ & ------ & 6.98 & 6.99 \\
\hline Ronozyme VP & 0.11 & ------ & 0.11 & ------ \\
\hline \multicolumn{5}{|l|}{ Calculated Nutrients } \\
\hline $\mathrm{ME}(\mathrm{kcal} / \mathrm{kg})$ & 3200 & 3200 & 2976 & 2976 \\
\hline Crude Protein $(\%)$ & 19.89 & 19.89 & 19.89 & 19.89 \\
\hline Methionine (\%) & 0.32 & 0.32 & 0.31 & 0.31 \\
\hline
\end{tabular}

${ }^{\mathrm{A}}$ Normal Energy with Enzyme Inclusion

${ }^{\mathrm{B}}$ Normal Energy with NO Enzyme Inclusion

${ }^{\mathrm{C}}$ Low Energy with Enzyme Inclusion

${ }^{\mathrm{D}}$ Low Energy with NO Enzyme Inclusion

${ }^{\mathrm{E}}$ full fat roasted soybeans

${ }^{\mathrm{F}}$ French pressed soybean meal

${ }^{\mathrm{G}}$ Supplied per kg of diet: vitamin $\mathrm{D}_{3}$, $3306 \mathrm{ICU}$; vitamin A, $8816 \mathrm{IU}$; vitamin E, $22 \mathrm{IU}$; vitamin $\mathrm{K}, 1.7 \mathrm{mg}$; thiamin, $1.1 \mathrm{mg}$; riboflavin, 5.5mg; niacin, $44 \mathrm{mg}$; D-pantothenic acid, $11 \mathrm{mg}$; pyridoxine $2.2 \mathrm{mg}$; folic acid $0.6 \mathrm{mg}$; biotin, $.03 \mathrm{mg}$; vitamin $\mathrm{B}_{12} ; .013 \mathrm{mg}$; choline $(0.05 \%$ inclusion $), 300 \mathrm{mg}$; calcium, $75 \mathrm{mg}$; sodium, $0.02 \mathrm{mg}$; potassium, $1.1 \mathrm{mg}$; magnesium, $21 \mathrm{mg}$; manganese, $144 \mathrm{mg}$; zinc $80 \mathrm{mg}$; iron, $32 \mathrm{mg}$; copper, $8 \mathrm{mg}$; iodine, $1.6 \mathrm{mg}$; selenium, $0.32 \mathrm{mg}$.

${ }^{\mathrm{H}}$ Washed Builders Sand 
Table 2. Diet formulations and nutrient parameters of conventional diet.

\begin{tabular}{|l|c|}
\hline \multicolumn{1}{|c|}{ Ingredients } & Conventional Grower \\
\hline Corn & 59.13 \\
\hline Soybean & 29.82 \\
\hline Soybean Oil & 3.67 \\
\hline Corn Gluten & 4.50 \\
\hline Defluorinated Phosphate & 1.20 \\
\hline Limestone & 1.10 \\
\hline Salt & 0.18 \\
\hline Poultry Premix ${ }^{\mathrm{A}} \mathrm{NB} 3000$ & 0.25 \\
\hline Methionine & 0.02 \\
\hline Coban 60 & 0.08 \\
\hline BMD 50 & 0.05 \\
\hline Calculated Nutrients & \\
\hline ME (kcal/kg) & 3200 \\
\hline Crude protein (\%) & 21.07 \\
\hline Methionine (\%) & 0.38 \\
\hline
\end{tabular}

${ }^{\mathrm{A}}$ Supplied per kg of diet: manganese, $0.02 \%$; zinc, $0.02 \%$; iron, $0.01 \%$; copper, $0.0025 \%$; iodine, $0.0003 \%$; selenium, $0.00003 \%$; folic acid, $0.69 \mathrm{mg}$; choline, $386 \mathrm{mg}$; riboflavin, $6.61 \mathrm{mg}$; biotin, $0.03 \mathrm{mg}$; vitamin $\mathrm{B}_{6}$, $1.38 \mathrm{mg}$; niacin, $27.56 \mathrm{mg}$; pantothenic acid, $6.61 \mathrm{mg}$; thiamine, $2.20 \mathrm{mg}$; manadione, $0.83 \mathrm{mg}$; vitamin $\mathrm{B}_{12}$, $0.01 \mathrm{mg}$; vitamin E, $16.53 \mathrm{IU}$; vitamin $\mathrm{D}_{3}, 2133 \mathrm{ICU}$; vitamin A, $7716 \mathrm{IU}$.

${ }^{\mathrm{B}}$ Active drug ingredient Monensin Sodium 60gpb (90g/ton inclusion)- Elanco Animal Health, Indianapolis, IN. As an aid in the prevention of coccidiosis caused by Eimeria necatrix, Eimeria tenella, Eimeria acervulina, Eimeria brunette, Eimeria mivati, and Eimeria maxima

${ }^{\mathrm{C}}$ Bacitracin Methylene Disalicylate 50g/lb (50g/ton inclusion)- Alpharma, Fort Lee, NJ. For increased rate of weight gain and improved feed efficiency. 
Table 3. Nitrogen-corrected apparent metabolizable energy and nitrogen-corrected true metabolizable energy.

\begin{tabular}{|c|c|c|}
\hline Treatment & $\begin{array}{l}\mathrm{AME}_{\mathrm{n}} \\
(\mathrm{kcal} / \mathrm{kg})\end{array}$ & $\begin{array}{l}\mathrm{TME}_{\mathrm{n}} \\
(\mathrm{kcal} / \mathrm{kg}) \\
\end{array}$ \\
\hline $\mathrm{NOR} / \mathrm{E}$ & $3173.98^{\mathrm{a}}$ & $3746.67^{\mathrm{a}}$ \\
\hline $\mathrm{NOR} / \mathrm{NE}$ & $3088.59^{\mathrm{ab}}$ & $3663.89^{\mathrm{ab}}$ \\
\hline $\mathrm{LOW} / \mathrm{E}$ & $3028.29^{b}$ & $3600.44^{b}$ \\
\hline LOW/NE & $2912.78^{c}$ & $3486.54^{\mathrm{c}}$ \\
\hline GROW & $3164.72^{\mathrm{a}}$ & $3737.73^{\mathrm{a}}$ \\
\hline $\mathrm{FOR} / \mathrm{E}$ & $364.89^{\mathrm{d}}$ & $541.83^{\mathrm{d}}$ \\
\hline FOR/NE & $285.39^{\mathrm{d}}$ & $462.66^{\mathrm{d}}$ \\
\hline P-value & 0.0001 & 0.0001 \\
\hline $\mathrm{LSD}^{\mathrm{A}}$ & 113.55 & 111.50 \\
\hline \multicolumn{3}{|c|}{3 Bird Types x 7 Dietary Treatments- Factorial Arrangement } \\
\hline Bird Type P-value & 0.2453 & 0.3609 \\
\hline Dietary Treatment P-value & 0.0001 & 0.0001 \\
\hline $\begin{array}{l}\text { Bird Type x Dietary } \\
\text { Treatment Interaction }\end{array}$ & 0.9845 & 0.9959 \\
\hline \multicolumn{3}{|c|}{ P-values for Enzyme vs. NO Enzyme Contrast } \\
\hline $\begin{array}{l}\text { Overall } \\
\text { Enzyme x No Enzyme }\end{array}$ & 0.2478 & 0.2609 \\
\hline $\begin{array}{l}\text { Feed } \\
\text { Enzyme x No Enzyme }\end{array}$ & 0.0213 & 0.0234 \\
\hline $\begin{array}{l}\text { Forage } \\
\text { Enzyme x No Enzyme }\end{array}$ & 0.1906 & 0.1903 \\
\hline
\end{tabular}

${ }^{\text {A}}$ Fisher's Least Significant Difference value

${ }^{\mathrm{a}-\mathrm{d}}$ Means within a column without a common superscript differ significantly $(\mathrm{P} \leq 0.05)$ 
Table 4. Nutrient Composition of forage ${ }^{1}$.

\begin{tabular}{|l|c|}
\hline \multicolumn{2}{|l|}{ Analyzed Nutrients } \\
\hline Moisture (\%) & 17.5 \\
\hline GE (kcal/kg) & 4263.6 \\
\hline Crude Protein (\%) & 17.60 \\
\hline Neutral Detergent Fiber (\%) & 31.17 \\
\hline Acid Detergent Fiber (\%) & 18.22 \\
\hline Amino Acids (\%) & \\
\hline Aspartic Acid & 1.56 \\
\hline Threonine & 0.67 \\
\hline Serine & 0.61 \\
\hline Glutamic Acid & 1.72 \\
\hline Proline & 0.78 \\
\hline Alanine & 1.00 \\
\hline Valine & 0.87 \\
\hline Isoleucine & 0.65 \\
\hline Leucine & 1.20 \\
\hline Phenylalanine & 0.77 \\
\hline Lysine & 0.89 \\
\hline Arginine & 0.83 \\
\hline Cysteine & 0.22 \\
\hline Methionine & 0.31 \\
\hline Tyrosine & 0.45 \\
\hline Values are expressed & \\
\hline
\end{tabular}

${ }^{1}$ Values are expressed on a dry matter basis 
Table 5. True amino acid digestibility of forage.

\begin{tabular}{|c|c|c|c|c|c|c|c|c|c|c|c|c|c|c|c|}
\hline & \multicolumn{15}{|c|}{ Amino Acids (\%) ${ }^{1}$} \\
\hline & Asp & Thr & Ser & Glu & Pro & Ala & Val & Ile & Leu & Phe & Lys & Arg & Cys & Met & Tyr \\
\hline FOR/E & 87.4 & 85.0 & 91.3 & 87.7 & 91.2 & 87.6 & 89.2 & 88.4 & 91.4 & 90.9 & 78.6 & 90.9 & 77.3 & 87.4 & 94.5 \\
\hline $\mathrm{FOR} / \mathrm{NE}$ & 87.0 & 82.2 & 89.6 & 86.4 & 86.1 & 86.8 & 88.2 & 87.9 & 90.6 & 90.1 & 80.0 & 92.3 & 73.5 & 88.3 & 95.3 \\
\hline P-value & 0.9300 & 0.6663 & 0.8324 & 0.8291 & 0.4607 & 0.8682 & 0.8694 & 0.9372 & 0.8806 & 0.8662 & 0.8882 & 0.8372 & 0.7882 & 0.8605 & 0.9096 \\
\hline \multicolumn{16}{|c|}{3 Bird Types x 2 Dietary Treatments- Factorial Arrangement P-values } \\
\hline Bird Type & 0.0893 & 0.1257 & 0.1025 & 0.0714 & 0.3028 & 0.0919 & 0.1126 & 0.1097 & 0.0864 & 0.1013 & 0.6373 & 0.9229 & 0.1183 & 0.1600 & 0.0849 \\
\hline Treatment & 0.9268 & 0.6568 & 0.8270 & 0.8190 & 0.4780 & 0.8619 & 0.8650 & 0.9348 & 0.8738 & 0.8604 & 0.8947 & 0.8477 & 0.7830 & 0.8599 & 0.9044 \\
\hline Interaction & 0.8844 & 0.7566 & 0.9607 & 0.9144 & 0.9270 & 0.8154 & 0.8308 & 0.7807 & 0.7455 & 0.7807 & 0.6111 & 0.4758 & 0.9014 & 0.9312 & 0.7597 \\
\hline
\end{tabular}

${ }^{1} \mathrm{Asp}=$ aspartic acid, Thr $=$ threonine, Ser $=$ serine, Pro= proline, Ala= alanine, $\mathrm{Val}=$ valine, Leu= leucine, Phe $=$ phenylalanine, Lys= lysine, Arg= arginine, Cys= cysteine, Met= methionine, Tyr= tyrosine 
Appendix I: Lignin and Non-Starch Polysaccharide Components of Common Cereal Grains, Cereal By-products, and Fiber Rich Materials

\begin{tabular}{|c|c|c|c|c|c|c|c|c|c|}
\hline \multicolumn{10}{|c|}{ NSP Content (\%) } \\
\hline & Corn & Wheat & Rye & Barley $^{A}$ & Oats $^{B}$ & Corn Gluten & $\begin{array}{l}\text { Grass } \\
\text { Meal }^{\mathrm{C}}\end{array}$ & $\begin{array}{l}\text { Grass } \\
\text { Meal }^{D}\end{array}$ & Alfalfa \\
\hline Lignin & 1.1 & 1.9 & 2.1 & 0.9 & 3.2 & 0 & 16.2 & 15.3 & 12.8 \\
\hline ß-glucan & 0.1 & 0.8 & 1.6 & 4.2 & 4.1 & 0.1 & ----- & ----- & ----- \\
\hline Cellulose & 2.2 & 2.0 & 1.6 & 1.0 & 1.4 & 0.5 & 16.2 & 19.5 & 13.9 \\
\hline \multicolumn{10}{|l|}{ Soluble NSPs } \\
\hline Arabinose & 0.3 & 0.7 & 1.2 & 0.3 & 0.3 & 0.1 & 0.5 & 0.4 & 0.7 \\
\hline Xylose & 0.2 & 0.9 & 2.0 & 0.4 & 0.2 & 0.1 & 0 & 0 & 0.4 \\
\hline Mannose & 0.2 & 0.2 & 0.2 & 0.1 & 0.1 & 0.3 & 0.3 & 0.3 & 0.1 \\
\hline Galactose & 0.1 & 0.2 & 0.1 & 0.1 & 0.2 & 0 & 0.3 & 0.3 & 0.5 \\
\hline Glucose & 0.1 & 0.4 & 0.6 & 4.1 & 4.5 & 0.2 & 0.2 & 0.5 & 1.1 \\
\hline Uronic Acids & 0.1 & 0.1 & 0.1 & 0.1 & 0.2 & 0 & 2.3 & 1.4 & 4.7 \\
\hline \multicolumn{10}{|c|}{ Insoluble NSPs } \\
\hline Arabinose & 1.9 & 2.2 & 2.4 & 1.7 & 1.0 & 0.3 & 2.1 & 2.4 & 1.8 \\
\hline Xylose & 2.8 & 3.8 & 4.1 & 2.4 & 2.1 & 0.3 & 8.5 & 9.4 & 5.2 \\
\hline Mannose & 0.1 & 0.1 & 0.3 & 0.3 & 0.2 & 0 & 0.3 & 0.2 & 0.6 \\
\hline Galactose & 0.4 & 0.2 & 0.4 & 0.2 & 0.2 & 0 & 0.8 & 0.9 & 1.0 \\
\hline Glucose & 0.9 & 0.7 & 2.0 & 1.7 & 1.1 & 0.6 & 2.4 & 1.8 & 0.2 \\
\hline Uronic Acid & 0.6 & 0.4 & 0.3 & 0.1 & 0.3 & 0.2 & 2.4 & 2.5 & 2.5 \\
\hline Total NSP $^{\mathrm{E}}$ & 9.7 & 11.9 & 15.2 & 12.4 & 11.6 & 2.5 & 36.6 & 39.8 & 32.9 \\
\hline
\end{tabular}

*Modified from K.E. Bach Knudsen, 1997. Carbohydrate and lignin contents of plant materials used in animal feeding. An. Feed Sci. and Tech., 67:319-338.

${ }^{\mathrm{A}}$ Hulless Barley

${ }^{\mathrm{B}}$ Hulless Oats

${ }^{C}$ First-Cut Grass

${ }^{\mathrm{D}}$ Third-Cut Grass

${ }^{\mathrm{E}}$ Only select compounds were chosen for table. Values within a column may not equal \% Total NSP. 
Appendix II: Composition and properties of non-starch polysaccharide enzyme

\begin{tabular}{|l|c|}
\hline Composition & 1g contains \\
\hline$\beta$-glucanase from Aspergillus aculeatus (dehydrated) & $70 \mathrm{mg}$ \\
\hline Dextrin & $40 \mathrm{mg}$ \\
\hline Cellulose & $70 \mathrm{mg}$ \\
\hline Hydrogenated vegetable oil & $70 \mathrm{mg}$ \\
\hline Calcium carbonate & $90 \mathrm{mg}$ \\
\hline Kaolin & $120 \mathrm{mg}$ \\
\hline Sodium sulphate & $540 \mathrm{mg}$ \\
\hline
\end{tabular}

\begin{tabular}{|l|c|}
\hline Properties & $1.1 \mathrm{~g} / \mathrm{mL}$ \\
\hline Bulk Density & $550 \mu \mathrm{m}$ \\
\hline Average Particle Size & $50 \mathrm{FBG} / \mathrm{g}^{\mathrm{A}}$ \\
\hline Declared Activity (minimum) & $300-1200 \mathrm{~g} / \mathrm{tonne}$ \\
\hline Dose Recommendation & $8.0-9.0$ \\
\hline Average pH value & \\
\hline
\end{tabular}

$\mathrm{A}_{\text {activity of Fungal Endo-1,3(4)- } \beta \text {-glucanase in one gram of product }}$ 


\section{Appendix III. Cecectomy Surgery Procedure}

A small area along the wing vein was plucked and alcohol was applied to the site.

Sodium pentabarbitol $(65 \mathrm{mg} / \mathrm{mL})$ was injected into the wing vein, at a dosage of 20-30 $\mathrm{mg} / \mathrm{kg}$, using a $3 \mathrm{~mL}$ syringe and a 26 -gauge needle. After properly anesthetizing the bird, the right leg was suspended over the ribcage and the feathers along the surgical site were removed. Betadine was evenly applied throughout the entire surgical site to reduce chances of infection. The analgesic lidocaine was injected in a $1 \mathrm{~mL}$ dose into the muscle surrounding the surgical site using a syringe and a 25 -gauge, 5/8-inch needle. A 1.5 -inch horizontal incision was made along the lower left abdomen using a 10-blade scalpel. Tweezers and iris surgical scissors were used to cut and separate muscle layers until the peritoneal cavity was exposed. The intestine and attached ceca were pulled through the incision using Allis tissue forceps. After the ceca were located, the tissue was ligated using hemostats. 2-0 silk sutures were placed along the intestinal wall and the ceca were removed. The entire abdominal cavity was saturated with penicillin to prevent infection and the muscle layer and dermal layer were sutured using 3-0 chromic gut suture and a $3 / 8$ reverse cutting needle. Throughout the duration of the procedure, reflexes were monitored by pinching the comb of the bird. Following the conclusion of the surgery, the birds were returned to raised wire cages and provided ad libitum feed and water. Iodine was administered along the surgical site. Oxytetracycline was injected intramuscularly once a day for three days. 


\title{
Protocol Statement
}

\section{West Virginia Lniversity Animal Care and Use Committee}

\author{
Research Compliance Office, 886 Chestnut Ridge Road \\ PO Box 6845 phone (304) 293-7073 fax (304) 293-7435
}

1. lrotucol ritle

Nutritional Profile and Fecd Restriction Effects on Performance of Organically Reared Broiler Chicken

2. P'rincipal Invesigaior (Instructor) Pl Joe S. Moritz

Position Assistant Professor

Department Animal and Veterinary Sciences POBOx

6108 Phone

(304) 293- Fax

$(304) 293-22.32$

$2631 \times 4435$

$\mathrm{HA} X \mathrm{ES}^{x} 15 \quad \mathrm{PP} X \mathrm{EP}^{3} 15$

AW* $X *$ Explanation for Codes

3. Other Personnel (See pancl above for insiructions)
Name
Department
POBOX
Plant \& Soil Sci 6108
William B. Bryan
lames O. Gekara
Plant d Soil Sci
6108

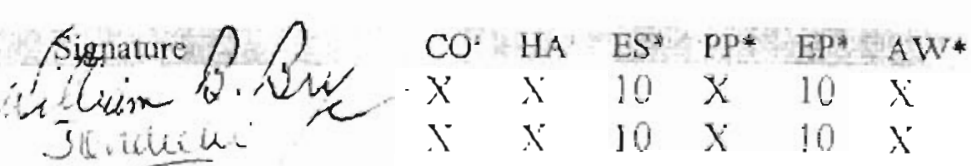

4. For Acalcinic Course: Course Number

Estimated $\neq$ of Studenrs

When Otfered

5. (Tamificatiun of Protacel New > Renewal (Cument protocol Xumber)

If the prutocol is a Renewal of a Research Project, submit a progress report of 500 words or less to the ACUC.

6. Tears Requested 1 year 2 year zears $\lambda$

7. Signatures

Ac the Principal irvestigator (Instructor), I am responsible for assuting that the conduc: of all procedures and any animal cark provided outsida of centralized animal holding facilities or areas comply with all applicable standards and regulations. 1 have read and am familiar with the appropriate federal regulations and standards for animal care and use. I certify that ail proposei animal use is necessary for this project and will be carried out within the provisions of the Auimal Welfare Act, Public Healit Service Policy on miversity regulations, Policies or guidelines. All other personnel involved in animal use under this protocol will be educated in their responsibilities prior to the use of animals. I also understand that any changes in to this project must br reviewed and approved by the WVU Animal Care and Use Commitze before implementation.

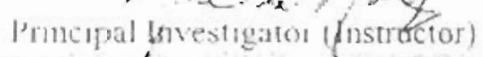
$2 / 27 / 63$
I approvel the submission of this Animal Care and Use Protocol to the WVU Animal Care and Use Committee.

Wepartment (hat
If the Principal lnvestigator (Instructor) is the Dept. Chair, the Associate Chair or a senior faculty member must sign in the Chair's place

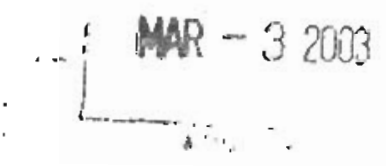


8. Animal Information (complete this page for eacli species used)
Scientific Name
Common Name
Strain/ Stock/Breed
Sex
Gallus domesticus
Chicken
ROSS Broilers
Mixed
Age or Weight
Protocol Tolal Yearly Numbes
3420
1140
Expected Avg. Daily Consensus 380
Maintenance of a Breeding Colony

No $\lambda$
Source of Animals
Pilgrum Pride

1). Sites / rooms where Procedures will he Conducted

$\begin{array}{ll}\text { Nonsurgical procedures or conditions } & \text { Facility* } \\ & \text { Horticulture Farm }\end{array}$

Bldg/koom

Portable

houses

Vonsurwial surgery

Survival surgery

Postsurgical / Postanesthesia / Postprocedural Recovery

* Ir procedures will be conducted at one of the University facilities, specify above which site will be used for each type of procedure:

Facilities include: OLAR, Stewartstown Farm, Life Sciences Bldg., Wardensville (Reymann Memorial) Farm, Willow Bend

Farm, Potomac State College, Reedsville Farm.

Bldg/Rooms include: Food Animal Research Facility (FARF), Pole Barn, Dairy Barn, Sheep Barn, Beef Handling Area, Beef Holding Area, Poultry Barn, and Labs or Rooms within OLAR or the Life Sciences Building.

10. Animal Housing and Care

Atrach a completed Animal Housing and Care Request Form for each species (see last page). The Animal Housing and Care Request Form will be forwarded to either the Office of Labaratory Animal Resources (OLAR) or the College of Agriculture, Forestry and Consumer Sciences. Approval of the protocol does not guarantee accomirodations requested.

11. Special Animal Housing

Animals will be housed outside of the centralized animal holding facilutues or areas, such as in laboratornes, for:

$\begin{array}{llllll}\text { Special Housing } & \text { vo } & \text { Yes } & \text { If ves } & \text { Building / Site } & \text { Room Duration } \\ 12 \text { to } 24 \text { hours (Study Area) } & & & & \\ \text { Vore than } 24 \text { hours (Sateilite Facility) } & X & & \end{array}$

If yes provide

A Scientific justification for housing animals outside of the centralized animal holding facilities for more than 12 hours or more than 24 hours

N/A

B Describe housing for animals and who will provide daily care for animals maintained outside the centralized animal holding facilities for more than 12 hours or more than 24 hours

C Describe provisions for weekend, holiday, after-hours and emergency care for animals maintained outside the centralized anima! holding facilities or areas for more than 12 hours or more than 24 hours. 
12 Fund Source

Federal Name: ISDA

Funding Status: Pending

Active OSP\# 02-251 NEN

Anticinated Funding Period

$09 / 01 / 021008 / 31 / 05$

Application deadine

State Name:

Funding Status: Pending

Acuve OSPH

Anticipated Funding Period:

Application deadlue

Private Name:

Funding Starus: Pending

Acrive OSP

Anticipated Funding Period:

Application deadline

Internal Name:

Funding Status Pending

Active OSp

Anticipated liunding Period:

Application deadline

13. Lay Description

Briefly describe in nontechnical (lay) terms the goal of the project and the role of living vertebrate animals in the swork. Includ the benefits to be derived from the project. This description should be written so that it could be disseminated to the public througb the media and understood by a nonscientist. It is not intended for peer review purposes. Do not use a grant abstract or exceed the space provided. For an example of a lay description go to http://www.wvu.edw/rc/acuc/lay deschth Sales of organically produced food have risen $350 \%$ since 1990 indicating a growing demand for such food. The organic food industry is the fastest growing segment of US Agriculture, with sales amounting to an estimated $\$ 11$ billion last year alone. The US Dept of Agriculture has recently issued guidelines fo organic food production. The poultry project will fom part of the ongoing research on organic food production methods at the Horticulture Farm. Poultry research will compare organic production methods with a view to increase efficiency of production. Diets containing crystalline methionine and those without will be compared to determine whether chicken running freely and getting some of their nutrient needs from pasture need additional methionine in the mixed diet al all. All procedures will conform to standard organic lood production recommendations including feeds and feeding. 
14. Experimental (or Teaching) Design

A. Provide a flow diagram (o: verbal description if a diagram is not possible) showing how experimental groups for groups: used for teaching) and experimental (or teaching) procedures or conditions are integrated in the project. Indjcate clearly which groups will undergo which procedures or experimental conditions over what periods of time. Details of the experimental (or teaching) procedures or conditions should be described in the appropriate sections on the following pages.

Two organic feed types and feeding regimens will be compared, one feed type formulated to meet National Research Council recommendations with crystalline methionine and the other without methionine, each feed type will either be full fed or restricted. The chicken will be fed daily and allowed free access 10 drinking water. These birds will be handled the same way as on a fam plus they will be allowed a free run area. To monitor perfornance, these birds will be weighed weekly.

B. What (estimated) percentage of animals will be unusable due to unintended mortality or morbidity? 5

C. Describe any clinical problems that may arise from experimental manipulation.

None are expected

If the protocol involves only the observation of animals, stop here. 
15. Tonsurgical Experimental (or I eaching) Procedures or Conditions

A. Details of experimental (or teaching) procedures, including frequency of treannents per animal.

Diets fomulated from organically produced feed ingredients to meet National Research Council recommendations for chicken will be fed daily. One diet will contain crystalline methionine and the other one will not. From day 1 to 3 weeks of ayc. all birds will be fed a broiler starter diel ad lib (free choice). From 3 weeks until 8 weeks of age, one group of birds will be fed ad lib while another group will be restricted (10 encourage increased consumption of pasture). General management of the chicken will be like in a typical poultry farm.

B. If anesthetics, analgesics, tranquilizers, and /or experimental materials will be used durng nomsurgeal procedures. provide the following:

Anesthetics

$$
\text { Agent }
$$

Dose $(\mathrm{mg} / \mathrm{kg})$

Route

Frequency

Analgesics

Tranquilizers

Experimental Crystallinemethionine 100 Mixed with fecd Daily materials

C. Mechods that will be used to detect and evaluate pain and distress in animals and any steps planned to avoid or minimize pain or distress to animals, including the criteria used to determine when animals should be euthanized, if appropriate: Chicken will be observed daily. No pain or clinical illness is expected except that birds not receiving methionine may show signs of growth relardation. 
16. Nonsurvival Surgery (Note: Nonsurvival surgery docs ant include euthanasia followed by procedures conducted postmortemi)

A. Provide a description of the nonsurvival surgery

$\mathrm{N} / \mathrm{A}$

B. If anesthetics, analgesics, tranquilizers, and /or experimental materials will be used during nonsurvival surgery, provide the following:

Agent

Dose (mg $\mathrm{kg})$

Ronte

Frequency

Anesthetics

Analgesics

Tranquilizers

Experimental

materials

C. Methods (such as intraoperative monitoring techniques) that will be used to detect and evaluate pain and distress in animals and any steps planned to avoid or minimize pain or distress to animals, including the criteria used to determine when animals should be eutlianized, if appropriate: 
17. Survisal surgery

A. Provide a description of the surgery, including aseptic techniques. $\mathrm{N} / \mathrm{A}$

B. If anesthetics, nnalgesics, tranquilizers, and /or experimental materials will be used during survival surgery, provide the following:

Anestherics

$$
\text { Agent Dose }(\mathrm{mg} / \mathrm{kg}) \quad \text { Route }
$$

Frequency

Analgesics

Tranquilizers

Experimental materials

C. Methods (such as intraoperative monitoring techniques) that will be used to detect and evaluate pain and distress in animals and any steps planned to ayoid or minimize pain or distress to animals, including the criteria used to determine when animals should be euthanized, if appropriate: 
18. Multiple Major Survival Surgery

Provide scientific justification and the time proposed between procedures on the same ammai.

$\mathrm{N} / \mathrm{A}$

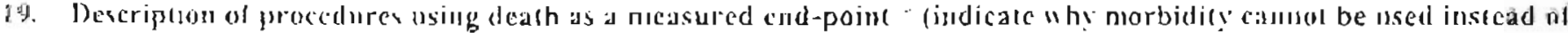
Inortality):

* Death as an end point refers to projects in which the animals' non-experimentally induced death is required as a measured dat point. It does not refer to projects in which the animals will be culhanized prior to non-experimentally induced death for tissue sample collection or project termination.

$\mathrm{N} / \mathrm{A}$

20. Euthanasia

Describe the methods used to euthanize animals.

Electrical stunning followed by exsanguinations (bleeding) will be used.

List the agen, dose in $\mathrm{mg} / \mathrm{kg}$ body weight and route of administration if applicable.

Agent Dose $(\mathrm{mg} / \mathrm{kg}) \quad$ Route

$\therefore A$

Provide Scientific Justification for methods that are not described as "Acceptable" by the American Veterinary Medical Association (AVMA) in 2000 Report of the AVMA Panel on Euthanasia', JAVMA Vol. 218, No. 5, 2001, p1.

The mothod stated above is accepted by AVMA for euthanizing poultry

21. Disposition of Animals Other than by Euthanasiz

If animals will not be euthanized as a part of the project, describe exactly what will be done with them (e.g., transfer to another project).

The chicken will be slaughtered for human consumption after body weights are taken. 
22. Sitared Biological Samples

If tissues, cells or other products derived from animals will be shared with other investigators during or after the project, describe this material and how it will be transferred. Provide reasons for the transfer, and give the name and address of the person receiving the material.

N/A

23. Traisportation of Animals by İmestigators

If you (instead of the animal care siaff or a commercial vendor/transporter) plan to pick up or deliver a shipment of animals, $c$ trausport animals out of doors, describe how you plan to conduct this move.

Chicken will be placed in poultry crates and transported in university vehicles.

24. Experimental Materials and Safety Considerations

$\begin{array}{lll}\text { Materials and Agents Used in Animals } & \text { No } & \text { Yes } \\ \text { Plammable or explosive materials (e.g. ether) } & \mathrm{X} & \\ \text { Brological samples of human origin } & \mathrm{X} & \\ \text { Biological materials (e.g transplantable tumors) } & \mathrm{X} & \\ \text { that might contain adventitious imfectious agents } & \end{array}$

Attach Radiation Safety Committee approval letters if appropriate. For Each Radioactive material, Infectious Agent including Oncogenic Viruses, Toxic Chemical or Carcinogen used in animals, complete the following:

Material ar Agent
Concentration

Llsed in Aninjals
Routc of

Administracion
Duration of Length of Time that

Fiposure Animals are Mantatner After Exposure 
25. Catcgory of Animal Use (Circle the corresponding lener(s) for all that apply)

* Ir Category B or C is chosen, complete the Refinement, Reduction, and Replacement Sections Below.

A. S Animals will not undergo procedures or experichce condilions that would normally cause more han ninmentury or slight pain or distress in tle absence of anesthetics, allalgesics or tranquilizers, which will nnt he adnunistered

13. " Animals may potentially experience more than momentary or slight pain or distress alld will receive anesshetics, analgesics or tranquilizers during or afeer the procedure or conditions listed holow. Alternatively, animals mas he culhanized 10 alleviate pain or distress. (Check all that apply)

Nonsurgical experımental or teaching procedures or conditions

Nonsurvaval surgery

Survival surgery

Postsurgical / Postanesthesia / Postprocedural recovery period

('. * Aninals may' potentially expericuce more than momentary or slight pain or distress and will anesthetics, analgesics or tranquilizers to alleviate pain or distress (cxeept for euthanasia when appropriate). Category C Scientific Justification for witholding anesthetics, analgesics or tranquilizers: 


\section{Refinement}

Refinement refers to efforts made $t o$ improve procedures and methods to:

1. Use fewer animals

2. Reduce trauma to the animals (either physical or stressful). This could include improvement in procedures that provide for better outcomes, shorter recovery times, lower morbidity and mortality

3. Achieve more definitive results

26. Describe the methods and sources enployed to determine the availability of alternatives to procedures that could potentially cause more than momentary or slight pain or distress.

The information requested in this section is required even if you plan lo alleviate pain or distress by the use of anesthetics, etc.

A. Database literature search: See AWIC Tips for Searching for Alternatives or at

http:/www nal usda gov/awic/alternatives/tips.htm

If a database $/$ literature search was used to determine the unavailability of alternatives to potentially painful of distressful procedures, complete the following:

1] Name of search engine used:

2) Database searched: Medline Other -.- Specify

3] Keywords used in the search and / or key references used to document the unavailability of alternatives:

4) Date of the search:

5) Years covered by the search:

B. If methods other than dalabase / literature searches were used, describe them below:

- Please sole that while consultation with experts is allowed for the purpose of obtaining Reduction. Refinement and Replacement (" $3 R^{\prime} s^{\prime \prime}$ ) information, it is generally discouraged by the USDA.

- If a consultation with an expert is used to obtan information on the " $3 \mathrm{R}$ 's." the following information about the consultation is required.

- Each component of the "3R`s" components. Reduction, Refinement and Replacement, must be addressed in the information from the expert

- The following information must also be provided:

Name of the expert

- Expert's academic degree(s) and tute of current position

Date of the consultation. If the consultation occurred at a meeting, provide the name, date and location of the meeting

2. The expent not only must have knowledge in the field of interest, he/she must also have current knowledge of the " $3 \mathrm{R}$ 's" information related to the field of interest. This special knowledge must be verified and described for each of the "3R's" components. Reduction, Refinement and Replacement.

( Results of the search

- Do relevant alternativos exist?

- If alternatives exist, why are they not adequate for this study? 


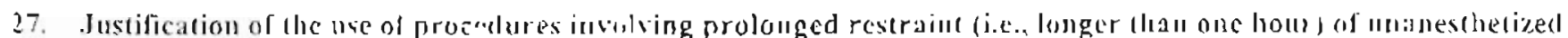
animals. Provide bcaibs ul lle resh ..in procedure and care of restrained animals.

NíA

\section{Replacenent}

Replacement refers to consideration of non-animal model altematives or the use of animals lower on the phylogenetic scale.

Some issues include:

1. Has computer modeling been employed to assess this subject? Why is computer modeling not relevant or sufficient for the goals of this study?

2. Can cell culture systems be substituted for the "animals"?

3. Can an animal lower on the phylogenetic scale be used as a model? For example, can a mouse or rat be used instead of a cat or a dog?

28. Rationale for using aninals rather than nonanimal alternatives

(in vitro systems, human clinical rials. comparer models, elc.)

Results of this research would be applied directly by organic poultry keepers. For lack of a more satisfactory way of carrying out research of this kind, chicken have to be used to simulate real conditions at the farm.

29. Justification of the choice of animal species

(hiterature, previous studies, unique anatomic or physiologic characteristics, erc.)

Chicken were chosen because data collected will directly apply to the same at tarn level.

Reduction

Reduction refers 10 efforts to minimize the numbers of animals utilized in animal studies. Some common issues might include:

1. Are the numbers of animals requested for each experimental group, the appropriate number to achieve statistically significant results?

2. Has a power test been performed to estimate necessary numbers?

30. Assurance that proposed project does not necessarily duplicate previous work: (Check one)

$X \quad$ This project does not duplicate previous experiments

Duplication is necessary Justufication: 
31. Justification for use of the number ol animals requested

Describe: a] the experimental (or teaching) groups and animals needed per group, and/or b] the quantity of biological samples. (e.g. tissue efc.) needed from animajs relative to the number of animals requested (e.g. quantity of sample that can be obtained from each aninal), and/or $\mathrm{c}$ ] the statistical analysis and results used io determine the number of auimals requested.

A large number of chicken. $380 /$ trial (3 trials will be rum/year for a total of 1140 chicken per vear) is baser on a power test that was performed to determine the appropriate number of birds needed to detect any significant treatment differences. 


\section{Animal Housing and Care Request Form}

Pre-8/02 Protocol Forms will not be reviewed

Research Compliance Use Only

Protocol \#

Date Submitted
OSP\#

- Complete One Request Form for Each Species

- Return this form to the Research Compliance Office with the Protocol Statement

- Submission of this request form does not guarantee the arrangements requested

- If you have any questions about animal housing and care arrangement, contact the appropriate office: the Office of Laboratory Animal Resources (OLAR) or the College of Agriculture, Forestry and Consumer Sciences

Principal Investigator (Instructor) Joe S. Morilz

Species to be used Chicken

1. Sites where aninals will be maintained

Health Sciences Center

X University Farm Speciry Site: Horticulture Farm

Eberly College of Arts and Sciences

Other Specify Site:

2. Rodents

A Room:

Siandard Room

Exclusive use of an animal room (subject to availability - Check with OLAR)

B Caging:

Conventional plastic bottom cage:

Conventional wire bottom cage:

Microisolator cage without sterile food, water or bedding

Microisolator cage with sterile food, bedding and water (acidified/auroclaved)

Other (explain):

C Housing:

Standard (typically the maximum number of animals per cage allowed by federal standards)

One anmal per cage

Other (explain)

D Care:

\section{Srandard}

Other (spectal light cycle, diet or water, technical assistance, etc): Contact OLAR

3. Non-Rodents

A Room or Animal Holding Area:

Standard

Other (explann:

B. Primary Enclosure (if applicable):

Standard

One animal per primary enclosure

Other (explann):

(. Housing or Animal Holding Arrangements:

Standard

One animal per primary enclosure

Othes (explasis):

D Care:

Standard

Oher (special hight cycle, diet or water, techuical assislance. etc): Conlact the college of Agriculture. Forestry and Consumer Sclences 


\section{Form Help}

* Explanation for codes

Back

Pl If the Principal hnvestigator (Instrucior) is a post-doctoral fellow, the faculty advisor must be listed as a co-investigatc (co-instructor) and sign as the faculty advisor. Students may not serve as principal investigators

CO Are you a co-investigator? (X)

HA Will you handle animals? $(X)$

ES Length of experience with species (in years)

PP Will you perform procedures? (X)

E fi l.ength of experience with procedures (in years)

AW Have you passed the test for Anima! Welfare Core Trainung at WVU? $(\mathrm{X})$

\section{For all applicable regulations, policies and guidelines}

Secrion

2. 3

$\mathrm{s}$

9

10

11

13

14

15

16

i7

18

19

20

21

22

23

24

35

26

27

28

29

30

31

\section{Section Hending}

Personnel performing procedures on animals

Animal Information

Sites : Rooms where Procedures will be Conducied

Animal Housing and Care

Special Animal Housing

Lay Description

Experimental (or Teaching) Design

Nonsurgical Experimental ior Teaching) Procedures or Conditions

Nonsurvival Surgery.

Survival Surgery

Multiple Major Survival Surgers

Description of Procedures using Death as a Measured Endpoint

Euthanasia

Disposition of Animals Other than by Euthanasia

Shared Biological Samples

Transportation of Animals by Investigators

Experimental Materials and Safery Considerations

Categorv of Animal Use

Alternatives to Potentialls Painful or Distressful Procedures

Iustification for the Use of Procedures Involving Prolonged Restraint

Rationale for Using Animals Rather Than Nonamimal Alternatives

Iustification of the Choice of Animal Species

Assurance that the Proposed Project Does Not Unnecessarily Duplicate Previous Work Justification for the Use of the Number of Animals Requested 


\title{
Dr. Pitts
}

Pre-11/02 Protocol Forms will not be reviewat Research Compliance Use Only is

Proiserl \#: $04-0201$ OSP\#

Reviewers

ind

\section{Protocol Statement}

\section{West Virginia University Animal Care and Use Committee}

\author{
Research Compliance Office, 886 Chestrut Ridge Road \\ PO Box 6845 phone (304) 293-7073 fax (304) 293-.7435
}

1. Protocol Tite Digestibility of Forage Feedstuffs for Poultry

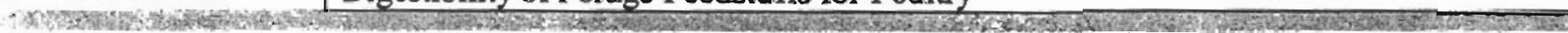

2. Principal Investigator (Instructor) PI* Joe Moritz, PhD. Position Assistant Professor

Department Animal and Veterinary Sciences
$\mathrm{HA}$
$\mathrm{H}$

3. Other Personnel (See panel above for instructions)

\begin{tabular}{|c|c|c|c|c|c|c|c|c|c|}
\hline Name & Department s s ing & POBOX & Signature & $\mathrm{CO}^{*}$ & $\mathrm{HA} *$ & ES* & $\widehat{P P *}$ & $\overline{E P}$ & $A W^{*}$ \\
\hline Nancy P. Buchanan & A\&VS & & & $\mathrm{x}$ & $\mathrm{x}$ & 1 & $\mathrm{x}$ & 1 & $\mathbf{x}$ \\
\hline Aniy S. Parsons & A\&VS & & & $\mathbf{x}$ & $\mathbf{x}$ & 2 & $\mathbf{x}$ & 2 & $\mathrm{x}$ \\
\hline & & & & & & & & & \\
\hline & & & & & & & & & \\
\hline & & & & & & & & & \\
\hline & & & & & & & & & \\
\hline & & & & & & & & & \\
\hline For Academic Courses & Course Number & N/A & Estimated & $\#$ of $S$ & tudents & & & & \\
\hline & When Offered & & & & & & & & \\
\hline
\end{tabular}

5. Classification of Protocol New $\sqrt{x}$ Renewal $\square$ (Current Protocol Number)

If the protocol is a Renewal of a Research Project, submit a progress report of 500 words or less to the ACUC.

6. Years Requested 1 year $\square 2$ years $\square 3$ years $\mathrm{X}$

7. Signatures

As the Principal Investigator (Instructor), I am responsible for assuring that the conduct of all procedures and any animal care

provided outside of centralized animal holding facilities or areas comply with all applicable standards and regulations. 1 have

rezd andam familiar with the appropriate federal regulations and standards for animal care and use. 1 ceitify that all propcsed

animal use is necessary for this project and will be carried out witin the provisious of the Animal Welfare Act, Public Healfi

Subice Policy on miversity regulations, Policies or guidelines. All ther personnel involved in animailuse under this protocol wilibe educated in their responsibilities prior to the use of animals. Ialso understand that any changes in to this project iny be reviewed and approved by the WVU Animal Care and Use Committee before implementation.

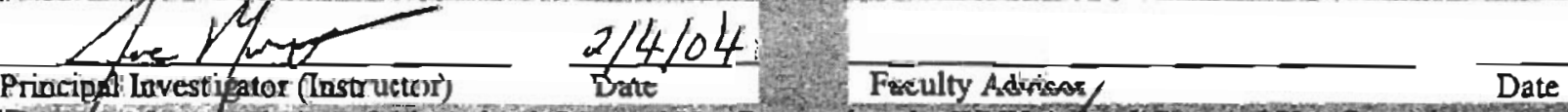
Tappro the submission of this Animal Care and Use Protocol to the WWO 7 .imal Care and Use Commite.

Department Chair $\frac{2 / 0+104}{\text { Date }}$

Dean

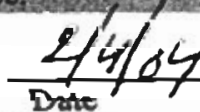

If the Principalinvestigator (Instruetor) is the Dept. Chair, the Associate Chair or a senifor faculy memiber must sign in the

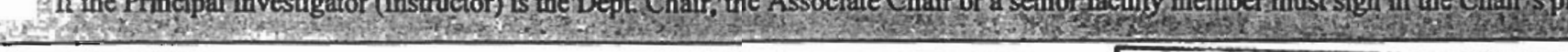

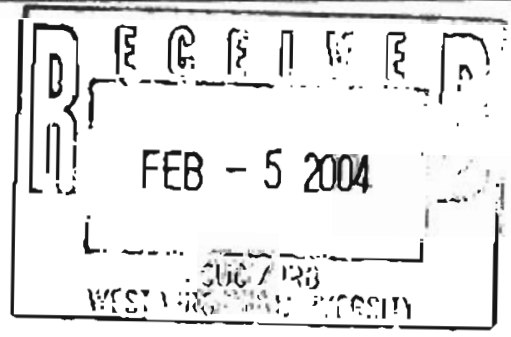


8. Animal Information (complete this page for each species vitar)

\begin{tabular}{|l|l|l|l|l|l|}
\hline Scientific Name & Common Name & Strain' Stock Breed & Sex & Age or Weight \\
\hline Gallus Domesticus & Chicken & White Leghorn Cockerels & Male & 18 weeks \\
\hline Protocol Total & Yearly Number & Expected Avg. Daily Consensus & Source of Animals & \\
\hline $408 \times 3$ & 136 & 68 & & Broilers, Commercial Source \\
\hline
\end{tabular}

9. Sites / rooms where Procedures will be Conducted

Nonsurgical procedures or conditions

Nonsurvival surgery

Survival surgery

Postsurgical / Postanesthesia / Postprocedural Recovery
Facility*

Rescarch Farm (Stewartstown Farm)

N/A

Research Farm (Stewartstown Fanw)
Bldg/Room

Poultry Bara

C

Poultry Barn

B

Poultry Barn

C
2 If procedures will be conducted at one of the University facilities, specify above which site will be used for each type of procedure:
Facilities include: OLAR, Stewartstown Farm, Life Sciences Bldg, Wardensville (Reymann Memorial) Farm, Willow Bend
Farm, Potomac State College, Reedsville Farm.
Bldg/Rooms include: Food Animal Research Facility (FARF), Pole Barn, Dairy Barn, Sheep Barn, Beef Handing Area, Beef.
Holding Area, Poultry Barn, and Labs or Rooms within OLAR or the Life Sciences Building.

10. Animal Housing and Care

Anach a completed Animal Housing and Care Request Fornin for each species (see last page). The Animal iloushig and

Care Request Form will be forwarded to eilher the Office of Laboratory Animal Resources (OLAR) or the Collgge of

Agriculture, Forestry and Consumer Sciences. Approval of the protocol does not guarantee accommodations requested.

11. Special Animal Housing

Animals will be housed outside of the centralized animal holding facilities or areas, such as in laboratories, for.

\begin{tabular}{|c|c|c|c|c|c|c|}
\hline Special Housing & No & Yes & If yes & Building / Site & Room & Duration \\
\hline 12 to 24 hours (Study Area) & $\mathbf{x}$ & & & & & 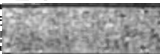 \\
\hline More than 24 hours (Satellite Facility) & $\mathbf{x}$ & & & & & \\
\hline
\end{tabular}

\section{If yes provide}

A. Scientific justification for housing animals outside of the centralized animal holding facilities for more than 12 hours

or more than 24 hours

N/A

B. Describe housing for animals and who will provide daily care for animals maintained outside the centralized animal holding facilities for more than 12 hours or more than 24 hours

N/A

C. Describe provisions for weekend, holiday, after-hours and emergency care for animals maintained outside the centralized animal holding facilities or areas for more than 12 hours or more than 24 hours. N/A 
12. Fund Source

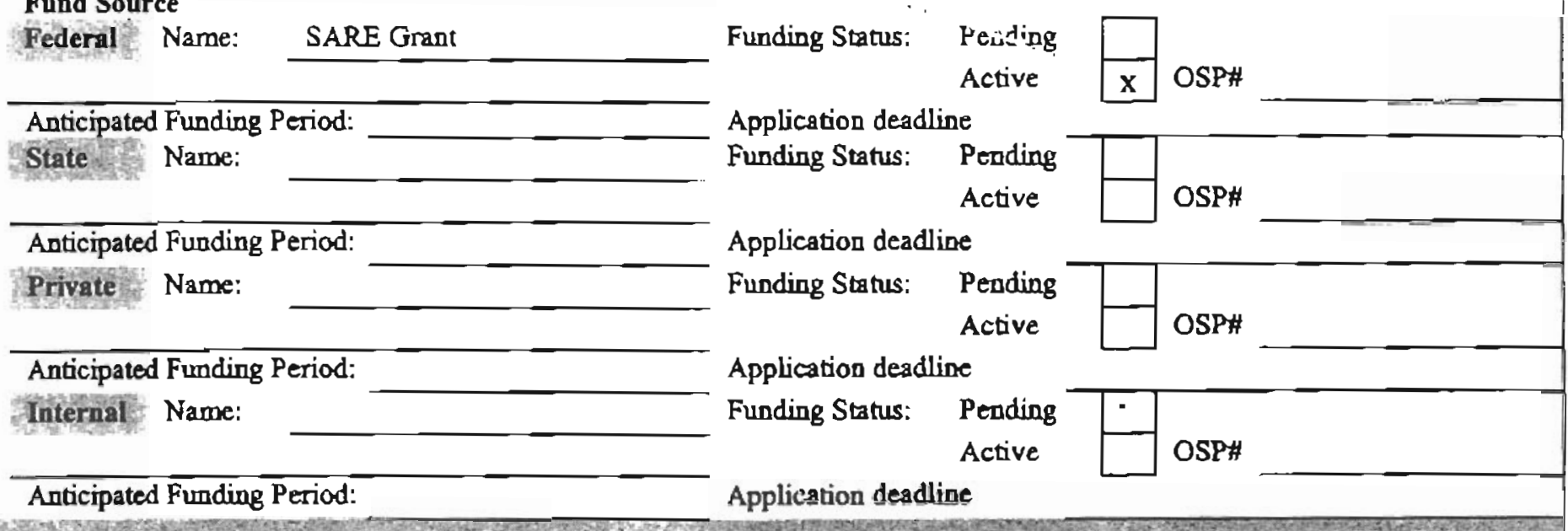

13. Lay Description

Briefly describe in nontechnical (lay) terms the goal of the project and the role of living vertebrate animals in the work. Include

the benefits to be derived from the project. This description should be written so that it could be disseminated to the public

through the media and understood by a nonscientist. It is not intended for peer reviewpurposes. Do not use a grant abstract or exceed the space provided. For an example of a lay description go to http:/www. wru. edu/rchlactuchay deschtom

There is a growing trend in the United States toward the consumption of home-grown and 'natural' products. In order to meet the demands of the consumers, the agricultural community is beginning to increase the production of organically grown products. There is also a growing number of small family farms that are reaping the benefits of the increasing demand for organic foods. In order to fully maximize the potential net profit a small operation can accrue, the accessible forage must be fully utilized by the colony of birds for growth and maintenance.

In these studies, the nutrient digestibility of chickens will be determined. Balance experiments will be used in which the chickens will be precision-fed forage samples. The nutrient value of these forage samples will be predetermined. The excreta will be collected from all birds and the nutrient value will be subtracted from the predetermined value of the forage. Thus, the less energy and nutrients excreted by the bird, the higher the forage digestibility. This will allow a small poultry producer to decrease his/her input into feed costs and rely more upon the forage that is readily available. 
i: Experimental (or Teaching) Design

A. Provide a flow diagram (or verbal description if a diagram is not possible) showing how exyerimental groups (or groups used for teaching) and experimental (or teaching) procedures or conditions are integrated in the project. Indicate clearly which groups will undergo which procedures or experimental conditions over what periods of time. Details of the experimental (or teaching) procedures or conditions should be described in the appropriate sections on the following pages.

Forage Sample Analysis

Block Design with Eight Treatments and Eight Replications Per Treatment

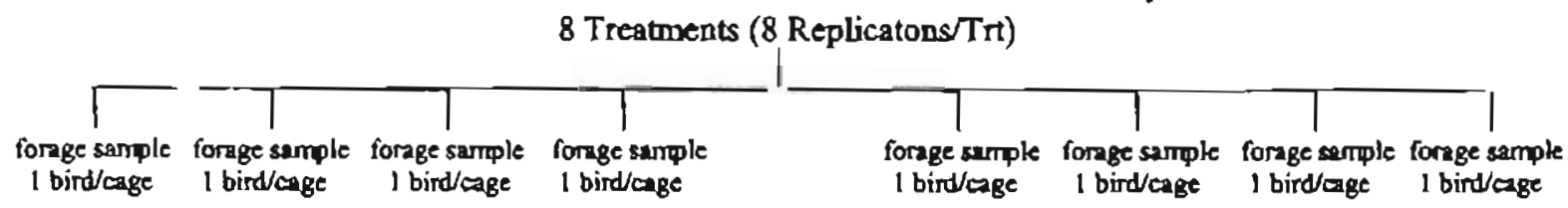

The birds will be obtained from a group of slip birds, cockerels that have mistakenly been placed in pullet houses. At eighteen weeks of age, the cecetomized birds will be individually housed in wire cages and fasted for 24 hours to clear any undigested material for the GI tract. Each bird will then be fed a predetermined amount of forage. This forage will be administered via a tube inserted directly into the crop.

During the duration of the experiment, the birds will have access to water ad libitum. In addition, the room will be heated to a temperature that will optimize bird comfort.

Excreta will be collected for 48 hours on plastic trays placed under the cages. Birds will then be returned to a standard com-soybean based diet that meets or exceeds NRC requirements. Excreta will be freeze dried, ground, and analyzed for gross energy, nitrogen content, amino acid content, phosphorus, and any other nutrients/chemicals of interest.

B. What (estimated) percentage of animals will be unusable due to unintended mortality or morbidity?

Moriz et. al. (2001), Nir et. al (1995), and Moritz et al. (2002) each calculated a morisitity rate of $5 \%$ in feed perfonmance studies. Therefore approxinately $5 \%$ more cockerels from this same group will be maintained on a control diet to replace mortality through the duration of the trial.

C. Describe any clinical problems that may arise from experimental manipulation.

It is not anticipated that birds will develop any problems after full recovery from the surgery. Extreme caution will be exercised during surgery as well as during the recovery period to minimize infection and discomfort. However, prior to surgery, the administration of the anesthetizing agent, Na pentobarbital, will need to be monitored closely and no more than $30 \mathrm{mg}$ per $\mathrm{kg}$ may be given. (Ketamine can be used as an alternative with a dosage of $10-20 \mathrm{mg} / \mathrm{kg} \mathrm{BW}$ ). During surgery, it will be necessary to use extreme caution to avoid damage and hemorrhage of the caudal mesenteric vein. The birds will also suffer a depression in feed consumption and weight gain post-surgery. However, feeding and normal activity should return within 24 hours and weight gain will return to normal within one week (Poultry Science 71: 1384-1390). 
15. Nonsurgicai Experimental (or Teaching) Procedures or Conditions

A. Details of experimental (or teaching) procedures, including frequency of treatments per animal.

Cecetomized birds will be housed in individual raised wire cages. Following a 24-hour fasting period, the birds will be removed from their cages and precision-fed one of eight forage samples. Birds will then be retumed to the cages and excreta will be collected on a plastic tray. All excreta will be collected for a period of 48 hours and freeze-dried, ground, and analyzed for nutrient content (gross energy, $N$, amino acids, $P$, and others).

Following the collection period, birds will have access to a diet that meets or exceeds NRC requirements and water will be provided ad libitum. In addition, the room will be heated to a temperature that will maximize bird comfort.

B. If anesthetics, analgesics, tranquilizers, and /or experimental materials will be used during nonsurgical procedumes, provide the following:

\begin{tabular}{|c|c|c|c|c|}
\hline & $A_{B}$ ent & Dose (mg/ $/ \mathrm{kg})$ & Route & Frequency \\
\hline \multirow[t]{3}{*}{ Anesthetics } & & & & \\
\hline & & & & \\
\hline \multirow{2}{*}{\multicolumn{5}{|c|}{ Analgesics }} \\
\hline & & & & \\
\hline & & & & \\
\hline & & & & \\
\hline \multicolumn{5}{|l|}{ Tranquilizers } \\
\hline & & & & \\
\hline & & & & \\
\hline \multirow{2}{*}{$\begin{array}{l}\text { Experimeotal } \\
\text { materials }\end{array}$} & & & & \\
\hline & & & & \\
\hline
\end{tabular}

Methods that will be used to detect and evaluate pain and distress in animals and any steps planned to avold or minimize pain or distress to animals, including the criteria used to determine when animals should be euthanized, if appropriate: Cockerels will be observed frequently during the duration of the experiment. Birds that have shown extreme discomfort or birds that have not resumed eating 48 following surgery will be euthanized by carbon monoxide exposure. 
16. Nonsurvival Surgt-: (Note: Nonsurvival surgery does not include euthanasia followed by procedures conducted postmortem)

A. Provide a description of the nonsurvival surgery

N/A

B. If anesthetics, analgesics, tranquilizers, and /or experimental materials will be used during nonsurvival surgery, provide the following:

\begin{tabular}{|c|c|c|c|c|}
\hline & Agent & Dose (mg/kg) & Route & Frequency \\
\hline \multirow[t]{2}{*}{ Anesthetics } & $N / A$ & & & \\
\hline & & & & \\
\hline \multirow[t]{2}{*}{ Analgesics } & $\mathrm{N} / \mathrm{A}$ & & & \\
\hline & & & & \\
\hline \multirow[t]{2}{*}{ Tranquilizers } & $\mathrm{N} / \mathrm{A}$ & & & \\
\hline & & & & \\
\hline \multirow{3}{*}{$\begin{array}{l}\text { Experimentsl } \\
\text { materials }\end{array}$} & $\mathrm{N} / \mathrm{A}$ & & & \\
\hline & & & & \\
\hline & & & & \\
\hline
\end{tabular}

C. Methods (such as intraoperative monitoring techniques) that will be used to defect and evaluate pain and distress in animals and any steps planned to avoid or minimize pain or distress to animals, including the criteria used to determine when animals should be euthanized, if appropriate:

N/A 
17. Survival surgery

A. Provide a description of the surgery, including aseptic techniques.

At the termination of the 24 fasting period, birds will be weighed so that a proper dosage of anesthesia can be determined. The small feathers along the inner surface of the wing will be plucked and the skin will be disinfected with a disposable alcohol swab. Sodium pentabarbitol $(65 \mathrm{mg} / \mathrm{ml})$ will be injected into the wing vein at a dosage of $20-30 \mathrm{mg} / \mathrm{kg}$. This will provide a constant anesthesia and eliminate pain during surgery. A $3 \mathrm{ml}$ syringe and 26 gauge needle will be used to slowly inject the Na pentabarbitol until the bird has been sufficiently anesthetized. Ketarnine (10-20 $\mathrm{mg} / \mathrm{kg} \mathrm{BW}$ ) can be used as an altemative to Na pentabarbitol. However, it is rarely used alone and is likely to be accompanied by benzodiazepines or alpha $a_{2}$-adrenergic agonists. Ketamine has also been associated with poor muscle relaxation, muscle tremors, and rough recoveries (International Veterinary Information Services, Aug. 5, 2001).

After successful anesthetizing of the bird, its right leg will be suspended over the ribcage and the feathers on the surgical site can be easily removed. Betadine will be sprayed between the leg joint and the tail and then evenly spread throughout the surgical area.

Lidocaine $(1 \mathrm{ml})$ will be injected into the muscle around the surgical site using a syringe and 25 gauge, 5/8 inch needle. A number 10 blade for a number 3 handle will be used to make a 1.5-2 inch horizontal incision along the lower left abdomen. The muscle will be separated using tweezer forceps to pull the tissue upward and iris surgical scissors to cut the layers. All surgical materials will be autoclaved or packaged in a sterile container and those performing the surgery will scrub prior to entering the room and wear sterile surgical gloves throughout the procedure.

After all layers of muscle bave been separated, the peritoneal cavity will be exposed and the intestine that is attached to the ceca can be pulled through the incision using Allis tissue forceps. While the tissue is exposed, it will be kept clean from blood with sterile gauze and kept moist with a sterile water solution.

Once the ceca are located, they will be ligated using hemostats, the remaining tissue will be sutured with 2-0 silk, and the ceca will be removed. The exposed cavity will then be saturated with Penicillin before closing the incision. A 3-0 chromic gut suture and a $3 / 8$ circle reverse cutting edge needle will be used to close the abdominal wall.

After surgery, a large amount of iodine will be applied to the surgical site and $1 \mathrm{ml}$ of oxytetracycline will be administered IM SW for three days. The bird will then be returned to its cage and observed approximately every 15 minutes throughout the recovery.

\begin{tabular}{|c|c|c|c|c|}
\hline & Agent & Dose & Route & Frequency \\
\hline \multirow[t]{2}{*}{ Anesthetics } & Sodium Pentabarbitol & $20-30 \mathrm{mg} / \mathrm{kg} \mathrm{BW}$ & Wing vein & 1 administration \\
\hline & Ketamine (altemative to Na Pent) & $10-20 \mathrm{mg} / \mathrm{kg} \mathrm{BW}$ & Wing vein & 1 administration \\
\hline \multirow[t]{2}{*}{ Analgesics } & Lidocaine & $1 \mathrm{ml}$ & MM of surgical site & 1 administration \\
\hline & & & & \\
\hline \multicolumn{5}{|l|}{ Tranquilizers } \\
\hline & & & & \\
\hline \multirow[t]{3}{*}{$\begin{array}{l}\text { Experimental } \\
\text { materials }\end{array}$} & Betadine & $\begin{array}{l}\text { Liberal } \\
\text { application }\end{array}$ & Surgical site & $\begin{array}{l}\text { Prior to surgery } \\
\text { Post-surgery }\end{array}$ \\
\hline & Peaicillin & $\begin{array}{l}\text { Liberal } \\
\text { application }\end{array}$ & Abdominal cavity & $\begin{array}{l}1 \text { administration } \\
\text { after removal of } \\
\text { coca }\end{array}$ \\
\hline & Oxytetracycline & $1 \mathrm{ml}$ & IM in leg & SD for 3 days \\
\hline
\end{tabular}


C. Methods (such as intraoperative mopitoring techniques) that will be used to detect and evaluate pain and distress in animals and any steps planned to arsid or minimize pain or distress to animals, including the criteria used to determine When animals should be euthanized, if apprurpiate:

During surgery, reflexes will be monitored using the comb-pinch reflex of the birds. In order to avoid pain, a 20 to $30 \mathrm{mg} / \mathrm{kg}$ dosage of $\mathrm{Na}$ pentabarbitol (or $10-20 \mathrm{mg} / \mathrm{kg}$ of Ketamine) will be used to ensure a deep anesthesia during the procedure. Breathing will be monitored throughout the surgety. 
18. Multiple Major Survival Surgery

Provide scientific justification and the time proposed between procedures on the same animal:

N/A

19. Description of procedures using death as a measured end-point (indicate why morbidity cannot be usad instead of mortality):

* Death as an end point refers to projects in which the animals' non-experimentally induced death is required as a measured data point. It does not refer to projects in which the animals will be euthanized prior to non-experimentally induced death for tissue $/$ sample collection or project termination.

N/A

20. Euthenasis

Describe the methods used to eithanize animals.

In the case of extreme discomfort, birds will be euthanized using carbon monoxide. The CO will be provided from a compressed cylinder. Air will be comprised of $4-6 \% \mathrm{CO}$ and death will be quick and painless.

List the agent, dose in $\mathrm{mg} / \mathrm{kg}$ body weight and route of administration if applicable.

\begin{tabular}{|l|l|l|}
\hline Agent & Dose $(\mathrm{mg} / \mathrm{kg})$ & Route \\
\hline Carbon Monoxide & & Inbalation \\
\hline & & \\
\hline
\end{tabular}

Provide Scientific Justification for methods that are not described as "Acceptable" by the American Veterinary Medical Association (AVMA) in '2000 Report of the AVMA Panel on Euthanasia', JAVMA Vol. 218, N0.5, 2001, p1.

The method stated above is accepted by the AVMA for euthanasia of poultry.

21. Disposition of Animals Other than by Euthanasia

If animals will not be euthanized as a part of the project, describe exactly what will be done with them (esg, transfer to annofieproject).

After completion of the current project the animais will be housed at the research farin and used for further digestibility studies. 
22. Shered Blological Samples

If tissues, cells or other products derived from animals will be shared with other investigators during or aiw the project, describe this maierial and how it will be transierred. Provide reasons for the transfer, and give the name and address of the person receiving the material.

N/A

23. Transportation of Animals by Investigators

If you (instead of the animal care staff or a commercial vendor / transporter) plan to pick up or deliver a shipment of animals, or transport animals out of doors, describe how you plan to conduct this move.

At 18 weeks-old, birds that are slips, male cockerels that were mistaken from hens and placed in pullet houses, will be transported to Poultry Barn C on the Stewartstown Farm at West Virginia University in Morgantown, West Virginia. The birds will be moved in a West Virginia University vehicle. These birds have already been vaccinated and would have otherwise been euthanized.

24. Experimental Materials and Safety Considerations

\begin{tabular}{|c|c|c|c|c|c|}
\hline \multirow{2}{*}{$\begin{array}{l}\text { Materials and Agents Used in Animals } \\
\text { Flammable or explosive materials (e.g. etber) }\end{array}$} & No & Yes & \multicolumn{3}{|l|}{ Specify } \\
\hline & $\mathrm{x}$ & & & & \\
\hline Biological samples of human origin & $\bar{x}$ & & & & \\
\hline $\begin{array}{l}\text { Biological materials (c.g. transplantable tumors) } \\
\text { that might contain adventitious infectious agents }\end{array}$ & $\mathbf{x}$ & & 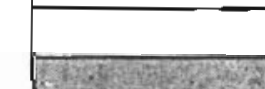 & stouge & 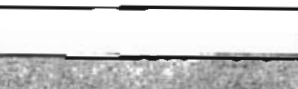 \\
\hline \multicolumn{6}{|c|}{$\begin{array}{l}\text { Attach Radiation Safety Committee approval letters if appropriate. For Each Radioactive material, Infectious Agent including } \\
\text { Oncogenic Viruses, Toxic Chemical or Carcinogen used in animals, complete the following: }\end{array}$} \\
\hline Materigl or Agent & $\begin{array}{l}\text { Concentr } \\
\text { Used in A }\end{array}$ & Imals & $\begin{array}{l}\text { Route of } \\
\text { Administration }\end{array}$ & $\begin{array}{l}\text { Duration of } \\
\text { Exposare }\end{array}$ & $\begin{array}{l}\text { Length of Time that } \\
\text { Animals ere Muinsined } \\
\text { Afler Expossure }\end{array}$ \\
\hline & & & & & \\
\hline & & & & & \\
\hline & & & & & \\
\hline & & & & & \\
\hline 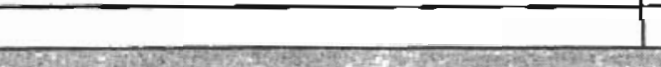 & 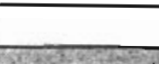 & & & & \\
\hline
\end{tabular}


25. Category of Animal Use (Circk the corresponding letter(s) for all that apply)

* If Category B or C is chosen, compiete the Refinement, Reduction, and Replacement Sections Below below.

A. $X$ Animals will not undergo procedures or experience conditions that would normally ceuse more than momentary or slight pain or distress in the absence of anesthetics, analgesics or tranquillzers, which will not be administered.

B. * Adimals may potentially experience more than momentary or slight pain or distress and will receive anesthetics, analgesics or tranqullizers during or after the procedure or conditions listed below. Alternatively, animals may be euthanized to alleviate pain or distress. (Check all that apply)

$\square$ Nonsurgical experimental or teaching procedures or conditions

$$
\mathrm{x}
$$
Nonsurvival surgery

$\mathrm{X}$ Survival surgery

$x$ Postsurgical / Postanesthesia / Postprocedural recovery period

C. * Animals may potentially erperience more than momentary or slight pain or distress and will nof receive anesthetics, analgesics or tranquilizers to alleviate pain or distress (except for euthanasia when appropriate). Category C Scientific Justification for withholding anesthetics, analgesics or tranquilizers: 


\section{Refinement}

Refinement refers to efforts made to improve procedures and methods to:

1. Use fewer animals

2. Reduce trauma to the animals (either physical or stressful). This could include improvement in procedures that provide for better outcomes, shorter recovery times, lower morbidity and mortality

3. Achieve more definitive results

26. Describe the methods and sources employed to determine the availability of alternatives to procedures that could potentially cause more than momentary or slight pain or distress.

The information requested in this section is required even if you plan to alleviate pain or distress by the use of anesthetics, etc.

A. Database liternture search: See AWIC Tips for Searching for Altematives or at

http:/www.nal.usda.gov/awic/alternatives/tips.htm

If a database / literature search was used to determine the unavailability of alternatives to potentially painful or distressful procedures, complete the following:

1] Name of search engine used:

2) Database searched: $\quad \square$ Medline $\quad x$ Other - Specify Agricola and EbscoHost

3] Keywords used in the search and / or key references used to document the unavailability of alternatives:

Alternatives, Cecetomy, Poultry, Metabolism

4] Date of the searcb: January 9, 2004

5) Years covered by the search: 1970-2004

B. If inethods other than database / literature searches were used, describe them below:

N/A

- Please note that while consultation with experts is allowed for the purpose of obtaining Reduction, Refinement and Replacement ("3 R's") information, it is generally discouraged by the USDA.

- If a consultation with an expert is used to obtain information on the " $3 \mathrm{R}$ 's, "the following information about the consultation is required.

- Each component of the "3 R's" components, Reduction, Refinement and Replacement, must be addressed in the information from the expert

- The following information must also be provided:

- Name of the expert

- Expert's academic degree(s) and title of current position

- Date of the consultation. If the consultation occurred at a meeting, provide the name, date and location of the neeting.

- The expert not only must have knowiedge in the field of interesh, he/she must also have curreat knowledge of the " $3 \mathrm{R}$ 's" information related to the field of interest. This special bnowledge must be verified and described for each of the " 3 R's" components, Reduction, Refinement and Replacement.

C. Results of the search

- Do relevant alternatives exist?

- If alternatives exist, why are they not adequate for this study?

Poultry Science 71: 1384-1390

Alterzatives to removing the ceca were investigated. Ligation of the ceca provided faster recovery for the birds. However, those birds had extremely moist excreta and discrete fecal boli were not present. After a 9 and 12-preek post-morem examination, fibrous tissue had formed around the surgical site and nutrient flow into the ceca had reoccurred. It bas not been determined that leaving the ceca in the body prevents microflora from becoming nonfunctional. An increase ia size of the ceca throughout the experiment also indicated that microflora are functioning in some manner. In order to prevent this and accurately determine digestibility of forage, all microflora activity must cease. Thus removal of the ceca is required. 
27. Justification of the use of procedures invoiving prolonged restraint (l.e, longer than one bour) of unanesthetized animals. Provide detalls of the restraln procedure and care of restrained animals.

N/A

\section{Replacement}

Replacement refers to consideration of non-animal model altematives or the use of animals lower on the phylogenetic scale. Some issues include:

1. Has computer modeling been employed to assess this subject? Why is computer modeling not relevant ot sufficient for the goals of this study?

2. Can cell culture systems be substituted for the "animals"?

3. Can an animal lower on the phylogenetic scale be used as a model? For example, can a mouse or rat be used instead of a cat or a dog?

28. Ratiouale for using azimals rather than nongnlmal alternatives

(in vitro systems, human clinical trials, computer models, etc.)

In order to properly analyze the digestibility of forage it is necessary to collect the excreta. It has not been determined how animals will respond to a reduction in a traditional diet while nutrient compensation is provided in the form of forage. Due to extensive microbial metabolism of nutrients in the ceca, the birds must be cecetomized to obtain meaningful and accurate data.

29. Justification of the choice of animal species

(iverature, previous studies, unique anatomic or physiologic characteristics, etc.)

Microbial fermentation is not an efficient means of digestibility in the monogastric stomach of the chicken even though it has two ceca. In order to study the role of the ceca in the fermentation and absorption of forage samples, cecetomized chickens must be used.

\section{Reduction}

Reduction refers to efforts to minimize the numbers of animals utilized in animal studies. Some common issues might include

1. Are the numbers of animals requested for each experimental group, the appropriate number to achieve statistically significant results?

2. Has a power test been performed to estimate necessary numbers?

30. Assurance that proposed project does not necessarily duplicate previous work: (Check one)

$\mathrm{X}$ This project does not duplicate previous experiments

Duplication ís necessary. Justification:

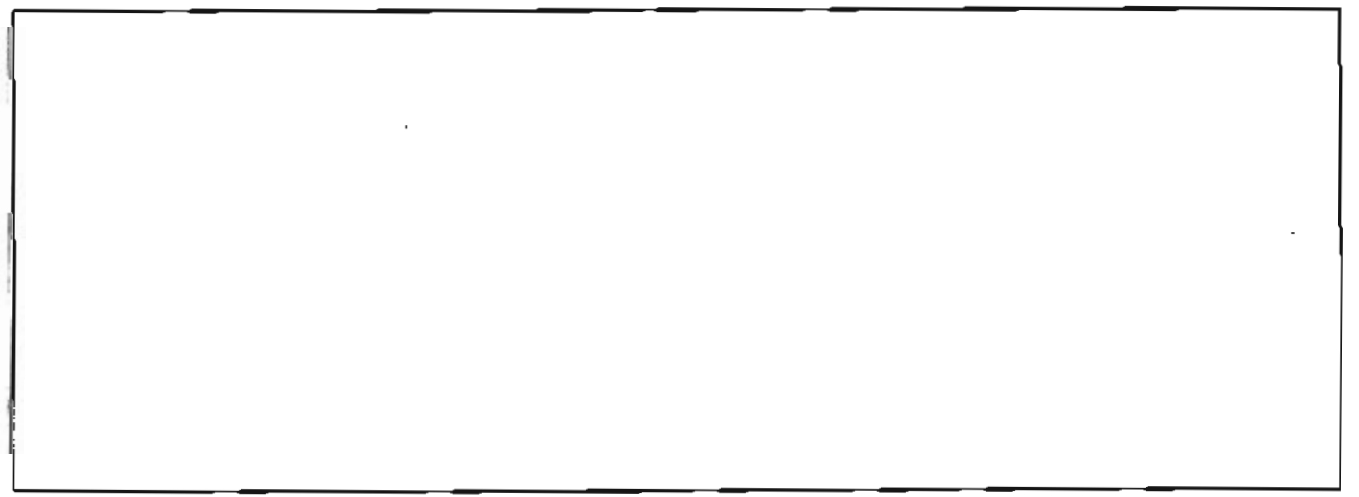


31. Justification for use of the number of animals requested

Describe: a] the experimental (or teaching) groups and animals needed per group, and/or b] the quantity of biological samples

(e.g. tissue etc.) needed from animals relative to the number of animals requested (e.g. quankity of sample that can be obtained

from each animal), and/or c] the statistical analysis and results used to determine the number of animals reguested.

In order to properly determine if the ceca of the bird plays a pivotal role in forage digestion, it is necessary to feed a higher number of birds. Many different forage samples will be tested for nutrient digestibility. Thus, it is necessary to be able to replicate our experimental design. It is also important to have replication for statistical analysis. Approximately 6-7 birds are needed per treatment (University of Illinois Laboratory Animal Care Advisory Committee, 2000) with 8 treatments for this particular study This number will be needed for a $1.5 \%$ standard error coefficient in digestibility studies. Another treatment of control birds, approximately 7 birds, will be needed where cecetomy is not necessary. 


\section{Animal Housing and Care Request Form}

Pre-8/02 Protocol Forms will not be reviewed Research Compliance Use Only

Protocol \#

Date Submitted

- Complete One Request Form for Each Species

- Return this form to the Research Compliance Omice with the Protocol Statement

- Submission of this request form does not guarantee the arrangements requested

- If you have any questions about animal housing and care arrangement, contact the appropriate office: the Ofice of Laboratory Animal Resources (OLAR) or the College of Agricuiture, Forestry and Consumer Sciences

Principal Investigator (Instructor) Joe S. Moritz Species to be used Broilers

1. Sites where animals will be maintained

1. Sites where Health Sciences Center

$\mathrm{X}$ University Farm Specify Site:

Eberly College of Arts and Sciences

Other Specify Site:

2. Rodents

A Room: 1 : 2 Stardard Room

Exclusive use of an animal room (subject to availability - Check with OLAR)

B Caging: Conventional plastic bottom cage

Conventional wire bottom cage

Microisolator cage without sterile food, water or bedding

- Microisolator cage with sterile food, bedding and water (acidified/autoclaved)

Other (explain):

C Housing: Standard (typically the maximum number of anionals per cage allowed by federal standards)

- Ooe animal per cage

Other (explain):

D Care: Standard

Other (special light cycle, diet or water, technical assistance, etc): Contact OLAR

3. Non-Rodents

A Room or Animal Holding Area:

$\mathrm{X}$ Standard

Other (explain):

B Primary Enclosure (if applicable); Standard

$\overline{\mathrm{X}}$ One animal per primary enclosure

Other (explain):

C Housing or AnimalHolding Arrangements Standiard

$\bar{X}$ One animal per primary enclosure

Other (explain):

D Care:

X Standard Other (special light cycle, diet or water, techoical assiscurce, etc): Contact the college of Agriculture, Forestry and Consumer Sciences 


\title{
Form Help
}

\section{Explanation for codes}

\section{Back}

PI If the Principal Investigator (Instructor) is a post-doctoral fellow, the faculty advisor must be listed as a co-investigator (co-instructor) and sign as the faculty advisor. Students may nol serve as principal investigators.

$\mathrm{CO}$ Are you a co-investigator? (X)

HA Will you handle animals? $(X)$

ES Leagth of experience with species (in years)

PP Will you perform procedures? $(X)$

EP Length of experience with procedures (in years)

AW Have you passed the test for Animal Welfare Core Training at WVU? $(X)$

\section{For all applicable regulations, policies and guidelines}

\author{
Section Section Berding \\ 2,3 Personnel Derforming procedures on animals \\ 8 Animal Information \\ 9 Sites / Rooms where Procedures will be Conducted \\ 10 Animal Housing and Care \\ 11 Special Arimal Housing \\ 13 Lay Description \\ 14 Experimental(or Teaching) Design \\ 15 Nonsurgical Experimental (or Teaching) Procedures or Conditions \\ 16 Nonsurvival Surgery \\ 17 Survival Surgery \\ is Muloiple Major Survival Surgery \\ 19 Description of Procedures using Death as a Measured Endpoint \\ $20 \quad$ Euthanasia \\ 21 Disposition of Animals Other than by Euchanasia \\ 22 Shared Biological Samples \\ 23 \\ 24 \\ Transportation of Animals by Investigators \\ Experimental Materials and Safery Considerations \\ Category of Animal Use \\ Altematives to Potentially Painful or Distressful Procedures \\ Justification for the Use of Procedures fovolving Prolonged Restraint \\ Rasionale for Using Animals Rather Than Nonanimal A iternatives \\ Justification of the Choice of Animal Species \\ Assurance that the Proposed Project Does Not Unnecessarily Duplicate Previous Work \\ Jusification for the Use of the Number of Animals Requested
}

